Portland State University

PDXScholar

TREC Final Reports

Transportation Research and Education Center

(TREC)

$12-2010$

\title{
Trail Planning \& Community Service Curriculum
}

Lynn Weigand

Portland State University

Follow this and additional works at: https://pdxscholar.library.pdx.edu/trec_reports

Part of the Transportation Commons, and the Urban Studies and Planning Commons

Let us know how access to this document benefits you.

\section{Recommended Citation}

Weigand, Lynn. Trail Planning \& Community Service Curriculum. OTREC-ED-10-04. Portland, OR: Transportation Research and Education Center (TREC), 2010. https://doi.org/10.15760/trec.6

This Report is brought to you for free and open access. It has been accepted for inclusion in TREC Final Reports by an authorized administrator of PDXScholar. Please contact us if we can make this document more accessible: pdxscholar@pdx.edu. 


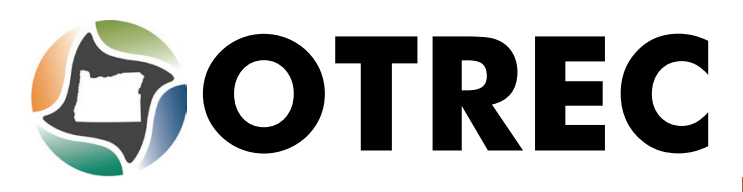

FINAL REPORT

\author{
Trail Planning \& \\ Community Service \\ Capstone Curriculum
}

OTREC-ED-10-04

December 2010 



\title{
TRAIL PLANNING \& COMMUNITY SERVICE CAPSTONE CURRICULUM
}

\author{
Final Report \\ OTREC-ED-10-04 \\ by \\ Lynn Weigand, Ph.D. \\ Portland State University
}

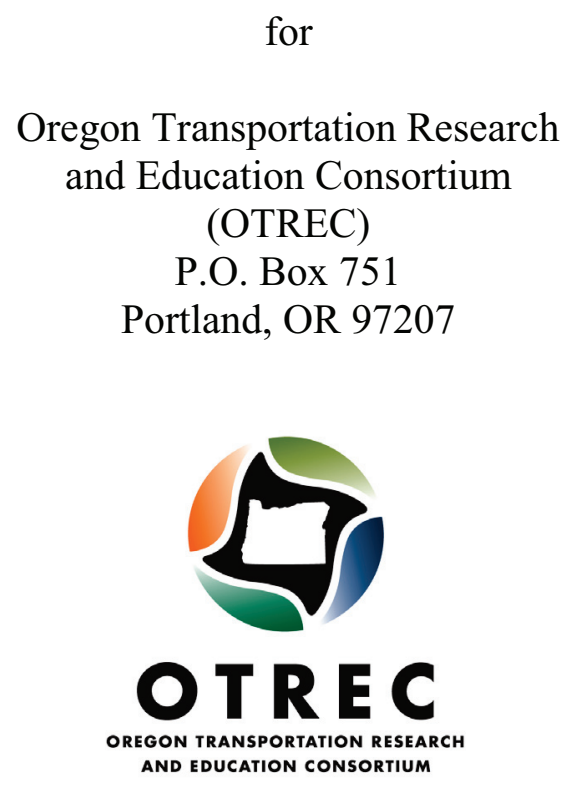

December 2010 



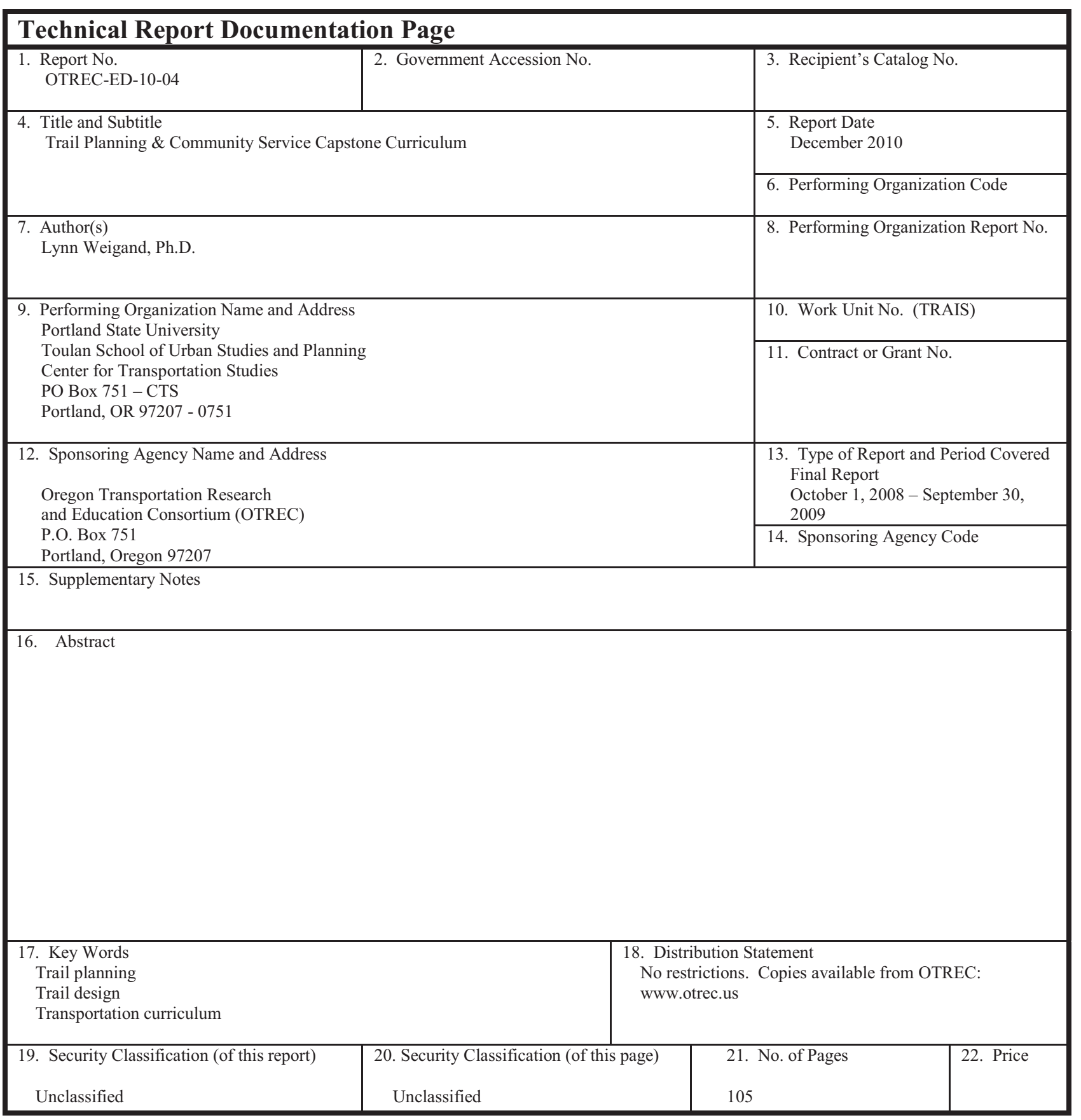




\section{ACKNOWLEDGEMENTS}

This project was funded by the Oregon Transportation Research and Education Consortium (OTREC).

\section{DISCLAIMER}

The contents of this report reflect the views of the authors, who are solely responsible for the facts and the accuracy of the material and information presented herein. This document is disseminated under the sponsorship of the U.S. Department of Transportation University Transportation Centers Program and the Oregon Transportation Research and Education Consortium (OTREC) in the interest of information exchange. The U.S. Government and OTREC assume no liability for the contents or use thereof. The contents do not necessarily reflect the official views of the U.S. Government or OTREC. This report does not constitute a standard, specification, or regulation. 


\section{TABLE OF CONTENTS}

$\begin{array}{ll}\text { Executive Summary } & 7\end{array}$

$\begin{array}{ll}\text { Background and Objectives } & 9\end{array}$

$\begin{array}{ll}\text { Project Description } & 11\end{array}$

$\begin{array}{ll}\text { Outcomes and Results } & 17\end{array}$

$\begin{array}{lr}\text { References } & 19\end{array}$

$\begin{array}{ll}\text { Appendices } & 21\end{array}$

- Course Outline

- Course Schedule

- Existing Conditions Report Assignment

- Trail Count Report Assignment

- Trail Inventory Form

- Pathway Count Form

- Instructions for Pathway Count Form

- Trail Survey

- Instructions for Trail Survey

- Mid-Term Evaluation from CAE

- Course Evaluation Form

- Student Presentations 


\section{Executive Summary}

\section{Overview}

The objective of this project was to develop a new trail planning curriculum and conduct a regional trail research project in the Portland metropolitan area. The curriculum was created for a community service-based, University Capstone course at Portland State University (PSU), with Metro (regional government) as the community course partner. Project goals included:

- Expanding opportunities for undergraduate students to study trail design and planning for transportation and recreational walking and bicycling;

- Providing practical application of knowledge to a trail planning project through research and data collection on trail use;

- Raising awareness of bicycle and pedestrian travel among students in disciplines other than planning and engineering;

- Fostering continuing involvement and interest in regional bicycle and pedestrian travel and trail development;

- Conducting research on the amount and type of use of identified regional trails to demonstrate their value in the regional transportation network; and

- Providing a model for trail planning and research curriculum.

\section{Background}

Trails can provide important transportation connections for cyclists and pedestrians in addition to their recreational benefits. However, trail design and planning is not covered in most university transportation courses, with only five percent including any discussion of this topic (Dill and Weigand, 2009). This project was intended to address the deficiency in this area by developing an undergraduate curriculum for trail planning, design and data collection that could be adapted for use in a variety of disciplines.

The curriculum was designed for a Senior Capstone course at PSU. This course was chosen because the Capstone experience integrates academic goals with a community-based learning experience; it draws students from all disciplines on campus; and each Capstone course has a community partner (public or nonprofit agency) that is an active participant in the course development and student experience. This course built on an existing relationship with Metro, the area's regional government, as a community partner for Capstone courses. Metro is responsible for transportation planning in the region and manages the regional trail system, including planning, design and data collection on trail use. Metro's planners have recognized that close-in trails can provide much-needed transportation options for bicyclists and pedestrian and they need data on trail use, specifically the number of pedestrians and cyclists that use the trails for transportation and functional uses, to further their planning efforts.

\section{Scope}

The course content focused on trail planning and design to encourage bicycle and pedestrian travel within the region with the Metro Greenspaces program as the community partner. The project included curriculum development, teaching, evaluation and curriculum revision.

The curriculum was designed with four objectives for the students to:

- Learn principles of transportation planning for bicycles and pedestrians;

- Understand trail design and integration into the transportation system; 
- Learn and apply basic data collection methods; and

- Apply course materials and research methods to collect data on trail use, analyze data and write a research report for the community partner (Metro).

The course included a significant field project in which the students worked with Metro staff to collect trail-use data, including use counts and intercept surveys, to determine the amount, type and motivation for trail use.

\section{Methods}

The principal investigator (Lynn Weigand, Ph.D., adjunct faculty member) worked with a graduate research assistant (GRA) and Metro staff to develop the course. This involved refining the course learning objectives; developing a course outline; researching and selecting resource and reading materials; creating course assignments and developing a field data collection project; and developing student evaluation methods and criteria. They worked with Dr. Jennifer Dill (co-PI) to design the research component, develop data collection methods and oversee data analysis. The course was held in the spring 2009 term and was taught by the PI and Metro staff members, assisted by the GRA. Six students enrolled in the course and completed projects on four segments of the urban trails system in Portland.

\section{Results}

The project culminated in a model curriculum that can be used for trail planning and design courses for undergraduate and graduate studies in planning and engineering programs at PSU, Oregon State University (OSU) and the University of Oregon (UO). The student project also provided Metro with data on trail use to aid their development of the regional trail system and more fully integrate trails with other routes and modes of travel. The resulting curriculum and project work is available on the IBPI website, where it can be uploaded by faculty at partner institutions within Oregon and transportation faculty in planning and engineering schools nationwide. 


\section{BACKGROUND AND OBJECTIVES}

\section{Project Background}

Trails provide alternatives to on-street routes for bicycle and pedestrian transportation that can help promote these modes of travel. At the same time, trails enhance the natural, built and economic environments of communities. According to the Rails to Trails Conservancy, communities must create seamless networks of accessible trails, sidewalks and on-road biking facilities to encourage active transportation, such as walking and bicycling. While advocacy organizations play a large role in raising public awareness and developing support for trails, they still must be planned and designed to be safe, accessible and integrated in a community's transportation and recreation network. Unfortunately, few, if any, courses exist at the undergraduate or graduate level to equip future professionals to do this. Curriculum for planners, landscape architects and engineers is already packed and leaves little opportunity to explore what are considered specialties or "niche" areas of expertise. Few, if any, courses currently exist that focus solely on trail development and design. Most professionals doing this work gained their experience on the job.

With the emphasis on promoting bicycle and pedestrian travel for health and environmental reasons, trails will assume a larger role in transportation networks. Communities will need more professionals with experience and expertise in all facets of trail planning and design to provide the technical assistance they need to plan an integrated trail system and design it to be safe and accessible for all. Trails need to meet all accessibility and safety requirements for pedestrian and bicycle travel, and they need to be sensitive to the natural environment in which they are located. Local jurisdictions also need data on how their trail networks are being used, and how they contribute to promoting bicycle and pedestrian transportation for local trips and commuting purposes. This requires a specific combination of skills and knowledge not provided in other transportation, planning or design courses.

This project is a first step toward meeting the need by developing a basic curriculum in trail planning and design that will cover topics such as characteristics of pedestrians and bicyclists; qualities of a good trail system; elements of safe and usable trail design; trail research and data collection methods; and principles of trail planning, including environmental considerations. In addition, the course is intended to provide a model for applied learning by including a service-learning component using the Portland region's trail network as the setting for a class project.

This type of course is clearly needed to begin to respond to the growing need for graduates with training in bicycle and pedestrian transportation, and specific knowledge of trail planning and design as it relates to these modes of travel. The Initiative for Bicycle and Pedestrian Innovation at PSU and Metro are uniquely qualified to partner on this course development. PSU currently offers some of the only bicycle and pedestrian planning and design courses in the nation and is considered a leader in this subset of transportation education. In addition, PSU's University Studies Capstone provides a unique, multidisciplinary service-learning opportunity. Metro, the regional government, manages an extensive regional trail network and has a highly qualified staff of trail planners who have many years of combined experience in the field. Taken together, these three resources provide the ideal setting to develop and test a curriculum on trail design and planning in one of the most bicycle- and pedestrian-friendly regions in the country. The resulting curriculum will provide a model that can be adopted and adapted by other programs in many disciplines to enhance the knowledge and practice of trail planning and design and improve our nation's trail network. The 
results of the trail research project will provide valuable data on the amount and type of trail use, with particular attention to the role of the regional trail system in promoting bicycling and walking. Trail use has the potential to promote healthy communities by encouraging walking and bicycling, which improve environmental quality and promote physical activity.

\section{Project Objectives}

The primary objective of this project was to provide future designers, planners and policy-makers with knowledge about trail planning, design and research methods as an integrated part of a community's transportation and recreation system to promote walking and bicycling.

Specific goals of this project were three-fold: developing and testing curriculum for an undergraduate course in trail design and planning; increasing awareness among a multidisciplinary group of students about the importance of trails as part of a complete walking and bicycling network; and collecting data about trail-use patterns in the Portland metropolitan region.

The process of developing the curriculum, teaching the course and evaluating both the course and outcomes resulted in a course curriculum that introduces students from a variety of disciplines to both the concepts of trail design and planning, and research methods on trail use. The course can be used in its entirety within a variety of departments, including planning, landscape architecture and engineering by faculty at other universities. In addition, course modules on planning, design and research can be adapted and integrated into a broader course curriculum on bicycle and pedestrian transportation, or recreational design and planning.

A secondary objective of the course was to raise awareness of bicycle and pedestrian travel among students in disciplines other than planning and engineering with the potential to both encourage them to use these modes of transportation for personal travel, and to become involved in regional bicycle and pedestrian travel and trail development. Offering this course through PSU's Capstone program provided a new opportunity for undergraduate students to study trail design and planning for transportation and recreational walking and bicycling, and generate interest in this field. The hands-on nature of the Capstone experience gave the students a way to apply the knowledge they acquired through the classroom learning to a community-based project. In addition, the students could see how their research would be used by Metro for future trail planning. Several of the students said that the course increased their interest in issues around bicycle and pedestrian planning and design, and motivated them to bicycle or walk more.

Finally, the course project and data collection provided useful information on trail use for the community partner, Metro, which will be used for future transportation and trail planning. The data collected, including counts of cyclists and pedestrians and surveys of their trail use for transportation and commuting purposes, will aid regional transportation planning efforts to promote these forms of travel. 


\section{PROJECT DESCRIPTION}

\section{Methods}

The course content focused on trail planning and design to encourage bicycle and pedestrian travel within the region with the Metro Greenspaces program as the community partner. The project included curriculum development, teaching, evaluation and curriculum revision. The curriculum included a significant field project in which the students worked with Metro staff to collect trail-use data, including use counts and intercept surveys, to determine the amount, type and motivation for trail use.

The PI (Lynn Weigand, Ph.D., adjunct faculty member) worked with David Amiton, a graduate research assistant (GRA), and Metro staff to develop the course. Metro staff included MaryAnne Cassin, Planning and Development Division Manger; Mel Huie, Senior Regional Planner with the Metro Greenspaces program; and other transportation planning staff. They met several times, beginning in November 2008, to prepare for the course and complete the following tasks.

\section{Refine Student Learning Objectives}

The team reviewed the proposed learning objectives for the course and agreed on five learning outcomes for the students:

- Understand principles of transportation planning for bicycles and pedestrians, and the integration of trails into a bicycle and pedestrian network;

- Develop knowledge of the qualities of good trail design for safety and accessibility;

- Learn and apply basic research data collection methods in the field;

- Apply course materials and research methods to collect data on trail use, analyze data and write a research report for the community partner (Metro); and

- Demonstrate knowledge of trail design and use as it applies to specific sites within the regional trail network.

\section{Develop Course Content and Outline}

Using the student learning objectives as a guide, the PI, co-PI and Metro staff discussed the scope of the course content and identified the following topic areas to include in the course:

- Bicycle and pedestrian travel behavior;

- Trail planning principles and practice;

- Research methods for trails, including site analysis and inventory, user counts and intercept surveys; and

- Writing and presentation skills.

The GRA conducted a web-based survey to identify existing trail-planning courses at the graduate and undergraduate levels, and did not find any full-term courses on the topic. The PI developed the course outline based on the learning objectives and topic areas identified by the project team. The final revised course outline is located in the Appendix.

\section{Research and Select Resource and Reading Materials}

The graduate research assistant conducted a database search to locate appropriate practices and scholarly literature on the topics identified by the project team. The project team reviewed the list, 
provided suggestions, and selected the final list of resource and reading materials for the course. The reading list is included with the course outline in the Appendix.

\section{Create Course Assignments and Research Project}

The core of the course was a service-learning project that integrated learning with hands-on project experience to apply the theoretical knowledge to a real-world situation. The project also was intended to build teamwork and communication skills. The student project was comprised of four research components listed below:

- Conducting an inventory and site analysis of the assigned trail segments;

- Conducting manual trail-user counts;

- Conducting intercept surveys; and

- Comparing manual count results to automated counts.

In addition, the students were required to compile their findings into a report and Powerpoint presentation for the Metro staff.

The first step in the process was selecting the trail locations for the project sites. The project team developed the following criteria to identify appropriate trail segments:

- High use (based on existing user counts);

- Easy access for students (near campus, accessible by bike, transit or foot);

- Safe for students to work in the field;

- Low potential for vandalism of the trail counters;

- Locations where trail users would be likely to slow or stop to take the survey; and

- Metro's data needs, including filling data gaps, providing inputs for modeling and supporting

future trail development.

Several project team members visited the potential sites and recommended the following trails and sites for the study:

- Springwater Trail at Spokane Street (Figure 1)

- Eastbank Esplanade between the Hawthorne and Morrison Bridges (Figure 2)

- Waterfront Park between the Hawthorne and Morrison Bridges (Figure 3)

- Willamette Greenway at Carolina Street (Figure 4)

These locations met all the criteria, and had the added advantage of being part of a larger trail "loop" system in which they all connect.

Figure 1: Springwater at Spokane Street

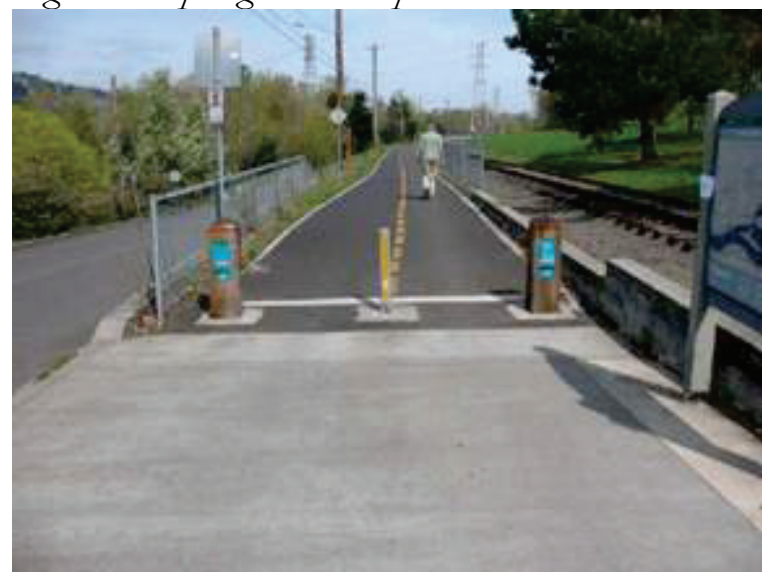

Figure 2: Eastbank Esplanade

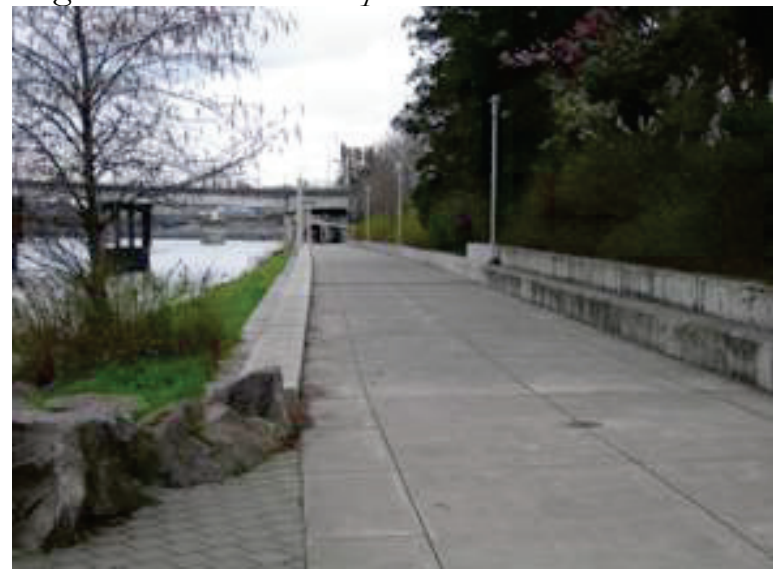




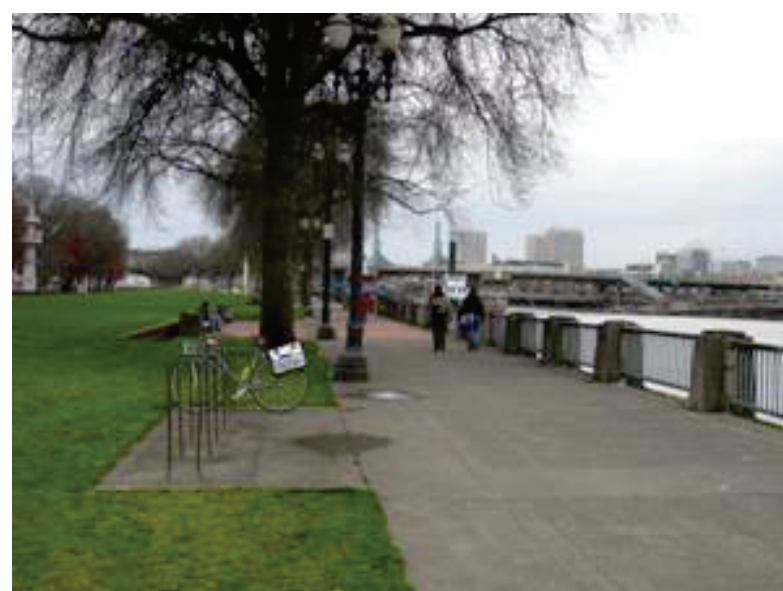

Figure 3: Waterfront Park

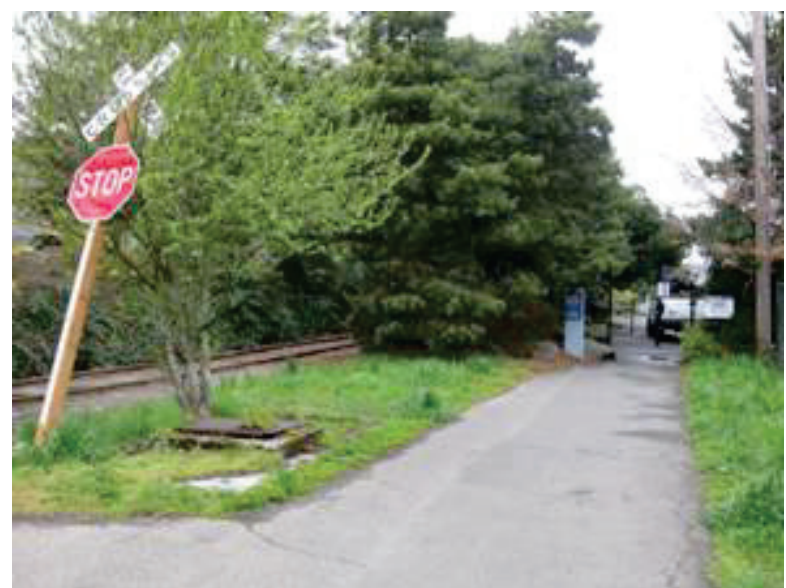

Figure 4: Willamette Greenway at Carolina

The project team also reviewed the strengths and weaknesses of several automated counters before selecting the EcoCounter for purchase. The GRA worked with Metro and City of Portland staff to arrange for installation of trail counters (the Eco-Counter and Metro's existing counter) and test them. The GRA obtained the data from the counters when it was available and provided it to the students.

The project team reviewed existing trail-count forms and intercept surveys used by the City of Portland, Metro and others, and developed the count and survey instruments for the student project. An important consideration was maintaining continuity with previous data collection efforts to ensure consistent data. Two members of the project team piloted the instruments in the field and made revision to the instruments and protocol based on their experience. These forms are included in the Appendix.

\section{Develop Student Evaluation Methods and Criteria}

The University Capstone program provides a mid-term evaluation of the course experience to provide feedback to the instructor during the course and conducts its own evaluation at the end of the course. Since these evaluations did not specifically address some of the goals of this course, the PI developed a supplemental evaluation to assist with the refinement of the course curriculum. This evaluation is located in the Appendix.

\section{Teach and Evaluate Trails Capstone Course}

\section{Course Teaching}

The course was offered spring quarter 2009 and was taught by the PI and Metro staff. Six students enrolled in the course. The number was less than anticipated, possibly because the course description was initially published incorrectly. While this was remedied when the error was found, it may have impacted students who registered early. The small number was a benefit because it allowed for more student interaction with the project team, and gave them more personal attention and assistance throughout the course.

The PI and GRA worked directly with the students on all aspects of their project. This included visiting the sites for orientation, explaining the data collection instruments, developing data entry forms, assisting with data entry and analysis, and developing templates for data presentation. The 
GRA examined trail-use data previously compiled to identify the best times and days for students to conduct their counts and surveys. A final schedule included both weekdays - mid-day and late afternoon - and weekend days. The work was conducted under a variety of weather conditions including rain, mild and hot weather during April and May 2009. Students coded and entered their data and conducted data analysis with assistance from the GRA.

The Metro staff reviewed and commented on the preliminary findings and data analysis. Students presented their projects to Metro officials, including one council member and the council president, in addition to staff, at the end of the quarter. Their work was well-received and the information will be used by the staff in their future trail-planning work.

\section{Mid-Term Evaluation}

Celine Fitzmaurice from the University's Center for Academic Excellence (CAE) conducted a midterm evaluation of the course on May 4, 2009. The CAE uses a standard format, has a conversation with the students, and provides feedback to the course instructors to consider for the remainder of the term. Overall, the students felt several of the course elements were helpful, including:

- Presentations that supported each other and provided continuity;

- Experience and knowledge of guest speakers;

- Interactive nature of class time, and accessibility to instructor and GRA;

- Class time for field work; and

- Provision of materials to do work and useful handouts.

Elements that the students thought could improve the course included:

- More interaction with the community partner (Metro) staff, and

- Focus readings on practical needs to complete the work.

Some students felt they would like to have more input on the design of the research methods and tools, where others liked having these already in place. From a practical standpoint, this would have been difficult for several reasons. First, in a 10-week course, there was barely enough time for the students to learn what they needed to complete the project and have adequate field time for data collection. In addition, Metro, the City of Portland, and the project team needed to ensure data was collected in a similar method to previous efforts so the data would be useful in comparisons and longitudinal studies. The project team took several weeks to prepare, pilot and revise the methods, which would not have been possible within the quarter. Finally, while some of the students had the requisite background to design research methods and instruments, several did not have the experience necessary to complete this task without significant assistance. Overall, the project team felt it was important to have the research design in place to ensure a successful student experience, especially with unfamiliar methods and data analysis. A complete summary of this evaluation is located in the Appendix.

\section{Final Course Evaluations}

The University Studies program also conducts a standard evaluation at the end of the course. This evaluation focuses more broadly on the goals of the Capstone program, including service-learning and community goals, and on the instructor. Overall, the course rated highly in the following areas:

- Community work helped better understand course content;

- Community work benefited the community; and

- Personal responsibility to meet community needs. 
These ratings indicate that the integration of academic learning with a hands-on project on this topic is valuable, and helps the students see and experience how their knowledge and work can be useful to the broader community.

The course-specific evaluation provided additional feedback. In general, the students felt the course was useful and gave them a new perspective on both trail planning and research methods. At least one student became interested in taking other courses in this area based on his experience in the class.

\section{Instructor Observations}

Selecting trail sections that were close-in was useful because it allowed for easy access by the students for the field work. In addition, pairing each team with two sites allowed them to compare and contrast use and user characteristics, and gave them more data for analysis. While some students felt that they would have preferred to have more input on the research design and methods, this was precluded by the time constraints of a 10-week quarter and the varying degrees of student knowledge and experience with research methods and data analysis. It was helpful to pre-test the counting and survey instruments and instructions because the testers found several items to clarify for students who may be inexperienced in either method.

It also was useful to set up the data entry forms and templates for data analysis for the students. While some students were familiar with Excel and data analysis, others were not. The GRA also spent time with each group to provide additional instruction on Excel spreadsheets and formatting charts and graphs for the final reports. 


\section{OUTCOMES AND RESULTS}

As described in the section above, the course received positive evaluations and the students felt it was a useful and valuable experience. We envision this curriculum will become a regular offering within the University Studies Capstone program, budget permitting, thus exposing more students to the benefits and possible career potential of bicycle and pedestrian travel. Students in future courses will be able to build on the data set generated by this class and provide Metro with ongoing data on regional trail use. In addition, the course has the potential to be expanded into an undergraduate and/or graduate course that could be offered for planning and engineering students at PSU, planning and landscape architecture at the UO, and engineering students at OSU.

The broader impacts of curriculum focusing on trail planning and design has the potential to attract more students to the profession of bicycle and pedestrian transportation as planners, designers and engineers - something that is needed as more emphasis is placed on these modes of travel within our nation's transportation network. All students involved in the course, regardless of educational background, will have a heightened awareness of the importance of bicycle and pedestrian transportation for community and personal health, and the role of trails in encouraging more walking and biking.

The course also enhances the capacity for research in two ways: Students in future courses will have training and application of trails research methods including data collection and analysis; and the research project will provide a model for student-based trails research projects which can be adapted by other communities with a base of students or volunteers who may be able to assist with data collection.

Finally, the distribution of curriculum will raise the awareness and increase interest in trail design and planning among faculty in several disciplines, including planning, landscape architecture and engineering. Even if institutions cannot offer a full course on trail planning and design, the curriculum and resources will provide a foundation for the development of course modules that can further student knowledge in this area.

\section{FURTHER ACTIVITIES}

The PI presented the results of the course development and curriculum in a poster session at the Active Living Research Conference in February 2010. In addition, the PI and GRA are developing two articles for publication: One based on the data of trail use and one based on the development of the curriculum.

The PI will post the curriculum and final report on the IBPI website and send notification to planning and engineering faculty at OSU and the UO with the link, and also to relevant associations of teaching faculty for planning, landscape architecture and engineering to disseminate the curriculum to a wider audience. This will help advance education and practice in the area of bicycle and pedestrian transportation in general, and the trail design and planning in particular. Equipping future practitioners to plan and design good trails that encourage walking and bicycling will result in healthy communities and healthier people. 


\section{REFERENCES}

Dill, J. \& Weigand, L. (2009). Transportation Curriculum Survey Report. Portland State University, Center for Urban Studies, Center for Transportation Studies, Initiative for Bicycle and Pedestrian Innovation, CUS-CTS-09-01. 


\section{APPENDICES}

- Course Outline

- Course Schedule

- Existing Conditions Report Assignment

- Trail Count Report Assignment

- Trail Inventory Form

- Pathway Count Form

- Instructions for Pathway Count Form

- Trail Survey

- Instructions for Trail Survey

- Mid-Term Evaluation from CAE

- Course Evaluation Form

- Student Presentations 



\section{METRO'S REGIONAL TRAIL SYSTEM \\ Senior Capstone • Spring 2009 \\ UNST 421/Section 527}

\section{COURSE INFORMATON}

\begin{tabular}{|c|c|c|c|}
\hline $\begin{array}{l}\text { Meeting Times } \\
\text { Location }\end{array}$ & $\begin{array}{l}\text { Monday/Wednesday } 9 \\
\text { UTS } 503\end{array}$ & :00 am & \\
\hline $\begin{array}{l}\text { Instructor } \\
\text { Office/Mailbox } \\
\text { Hours } \\
\text { Email } \\
\text { Phone }\end{array}$ & $\begin{array}{l}\text { Lynn Weigand, Ph. D. } \\
\text { URBN 350E } \\
\text { By Appointment } \\
\text { weigand@pdx.edu } \\
\text { 503.725.4042 }\end{array}$ & Graduate Assistant & $\begin{array}{l}\text { David Amiton } \\
\text { davidamiton@gmail.com }\end{array}$ \\
\hline
\end{tabular}

\section{INTRODUCTION TO THE COURSE AND COMMUNITY PARTNER}

Welcome to your senior Capstone! The community partner for this course is Metro, the regional government for the Portland metropolitan area. Metro's role encompasses a wide range of essential functions, including growth management and the urban growth boundary, transportation planning, solid waste and recycling, green spaces and parks, and management of a number of facilities, such as the Oregon Zoo, the Oregon Convention Center (OCC), the Expo Center and the Portland Center for the Performing Arts (PCPA).

This term, the course will focus on Metro's Regional Trails system. Working with Metro staff, you will explore Metro's role in planning, developing and maintaining its trail system. Course material will cover regional trail and transportation planning, trail design, trail use, and survey methodology. The majority of the course work will be focused on a project to gather and summarize information about trail condition and use that will involve a significant amount of work in the field. You will work in teams and work with one trail segment during the term to conduct your research and produce a final report on your findings that you will present to Metro at the end of the term.

\section{Metro Contacts}

Mary Anne Cassin, Planning and Development Division Manager, MaryAnne.Cassin@oregonmetro.gov

Mel Huie, Senior Regional Planner, Mel.Huie@oregonmetro.gov

Robert Spurlock, Robert.Spurlock@oregonmetro.gov

John Mermin, John.Mermin@oregonmetro.gov 
The course is designed to involve you in a meaningful project that will assist the community partner (Metro) in one of its program areas, and provide direct experience in researching and producing a meaningful product for the community partner.

\section{Specific Learning Objectives}

- Gain a basic understanding of Metro's role the region and its programs and services in general, and its role in planning and developing a regional trail system;

- Develop in-depth knowledge of the theory and practice of trail planning, design, and use; and

- Apply principles of field research to conduct a project documenting trail condition and use for the Metro staff

\section{Application of Learning Objectives}

- Integrate academic and theoretical knowledge and apply it to a community-based program.

- Gain experience in a team setting to establish goals, divide and assign work responsibilities, coordinate project production, and deliver a final product to the community partner.

\section{RELATIONSHIP TO CAPSTONE GOAL AREAS}

\section{Inquiry and Critical Thinking}

You will be introduced to several areas of inquiry: regional government, bicycle and pedestrian transportation, and trail planning, and trail use. This will require you to examine each of the fields separately and then to synthesize your understanding of both the content and methods for your final project.

\section{Communication}

You will gain communication skills in several settings through the course. First, you will be developing interpersonal communication skills through facilitated class discussions and interactions with representatives from Metro. You also will gain experience in group communication skills through your work on a team-based project. Finally, you will develop a specific communication skill, such as creating a presentation, web-based product or printed piece, and gain presentation experience by presenting your final product to the community partner and the class.

\section{Variety of Human Experiences}

This course will emphasize the diversity of cultures, ethnic origins, and class in two ways. You will be exploring issues of diversity, what it means, and how it applies to transportation and trail use in the region. Also, you will be interacting with your team members and community partner staff that will provide experience in working with people other than yourself.

\section{Ethical and Social Responsibility}

Through your work with Metro, you will gain an understanding of ethical considerations and social responsibilities of regional planning, including the needs to weigh rights of and obligations to diverse populations of constituents, the environment, regional partners and the economy. 


\section{EXPECTATIONS}

As the final Capstone, this course is a culmination of your undergraduate learning experience at PSU. As such, you should expect this class to demand a little more of your time and energy than others have taken. You should plan to spend about 12 hours per week outside of class working on this Capstone, including the time you spend reading, writing, preparing for class and working on your project.

According to the PSU Bulletin, "the grading system at the graduate level is defined as follows: A-Excellent; B-Satisfactory; C-Below graduate standard." Therefore, simply doing the required work does not warrant an A grade. Your work must be excellent to receive an A grade. Incomplete Grades

I will only assign an incomplete (I) grade when circumstances are consistent with PSU's policy on incomplete grades, shown below. "Circumstances must be unforeseen or beyond [your] control." In other words, I do not give incompletes for poor planning on your part, e.g. you got too busy with work and your other classes. If you do encounter unforeseen circumstances, approach me as soon as possible about entering into a written agreement for an incomplete grade.

Please consult the PSU Bulletin for complete information on incompletes.

As the classroom facilitator, I will strive to maintain the classroom as a safe place for discussion and debate. This requires some classroom ground rules that all students are expected to understand and follow during class. These ground rules will be reviewed during the first week of class and may be modified depending upon the input of the class.

- Be mindful of different personal experiences, backgrounds and positions

- $\quad$ Ask clarifying questions (as opposed to arguing)

- $\quad$ Respect the person who is talking and refrain from interrupting

In addition, the classroom learning environment works best when students act professionally and regular course period."

cooperatively with peers, partners and guests. You are encouraged to speak with me outside of class to ask questions or seek ways to communicate more effectively in the class or team setting.

\section{Late assignments}

Late assignments will be marked down one point per day, which is approximately one-third of a grade. As with incomplete grades, I generally do not allow students to turn things in late without assessing this penalty, except in unusual circumstances, e.g. medical emergencies. Having too much work in other classes or at work/internship does not count. All students have those challenges.

\section{GRADING POLICIES}

\section{Plagiarism and Citations}

Plagiarism will not be tolerated in this course. You must cite all of your sources in your work. Please review this web site about citations:

http://www.lib.pdx.edu/instruction/survivalguide/writeandcitemain.htm The general rule is that you must include enough information that the reader could find the original source. I am flexible about which style of citations you use, but you must use one style consistently. I recommend a style that places the author's name and year of publication in parentheses after the quote or reference, e.g. (Weigand, 2007) and discourage the use of numbered footnotes for the type of writing you will do for this class. 


\section{Overview of Coursework}

The coursework will include a combination of reading assignments, lectures, discussion, field work and a final project. The course is designed to give you the background and technical grounding early in the term so you will have a foundation for your project work. This means you can expect the first portion of the course to be heavier on readings and assignments, with the remainder of the course focused on the project work, including research, production and presentation. The project and field work is divided into segments that will form the basis for your final project and presentation. More specific criteria for each of these areas will be provided separately.

\section{Attendance and Participation (20\%)}

Attendance counts. You are part of a learning community and a project team, both of which require you to be prepared and to participate. Please let me know if you know that you will be missing a class so that we can make arrangements to help you keep up with the class and your team.

\section{Reading Assignments}

The course readings include the required text, and additional articles and web-based information that will be provided throughout the course. The assigned readings are designed to provide you with some background in two areas: Metro and regional government, and social marketing. In addition, you will need to seek additional source of information on your program's topic area using a variety of library, electronic and in-person research techniques.

\section{Project Work (80\%)}

This class focuses on a team-based project on trail conditions and use within the Metro region. Each team will be assigned to one trail segment for the term. The team will assess the existing conditions of the trail, conduct counts of users, conduct surveys of users, analyze the results of the counts and surveys, and produce a final report about their trail segment for the Metro staff. Following is a breakdown of the assignment of points for the course work.

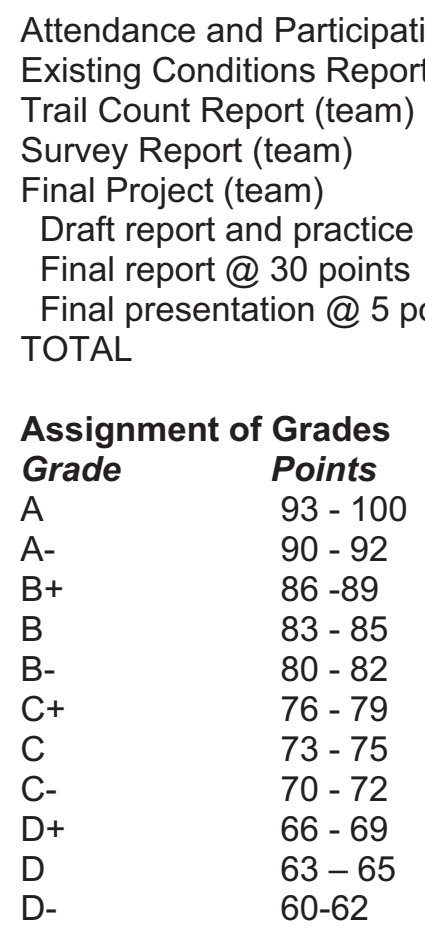

20 points

10 points

15 points

15 points

40 points

100 points 
The There will be a Blackboard site for the course. You must have an ODIN account to access Blackboard at bb.pdx.edu. If you're registered for the class and have an ODIN account, you'll be added to the course web site automatically.

\section{READINGS}

The required readings will cover Metro and it's regional trail system, technical information about trail planning and design, and background about the research methods you will be using. Other web-based readings or handouts may also be assigned throughout the course. Complete citations are listed here; readings are references in the course schedule.

\section{Required Readings}

Monday 3/30 Metro Website on Regional Trails and Greenways System: http://www.oregonmetro.gov/index.cfm/go/by.web/id=595 Connecting Green: http://www.oregonmetro.gov/index.cfm/go/by.web/id=24701 Metro Greenspaces Regional Trails System Map: http://www.oregonmetro.gov/files/planning/regionaltrailmap.pdf

Wednesday 4/1 Regional Trails \&^ Greenways Publication: http://www.oregonmetro.gov/files/planning/trailsgreenways.pdf Multi-Use Trails: Ensuring Successful Regional Planning: http://atfiles.org/files/pdf/multiuseplan.pdf

Monday 4/6 Portland's Trail Design Guidelines (Intro, Trail Type Matrix/Descriptions) http://www.portlandonline.com/parks/index.cfm?\&c=49181

Wednesday 4/8 AASHTO Bike Book: Shared Use Paths (document pgs 33-40) http://www.sccrtc.org/bikes/AASHTO_1999_BikeBook.pdf

Wednesday 4/15 Evenson, K. R., Herring, A. H., and Huston, S. L. (2005). Evaluating change in a physical activity with the building of a multi-use trail. American Journal of Preventative Medicine, 28(2S2), 177-185.

Lindsey, G., Han, Y.,Wilson, J., and Yang, J. (2006). Neighborhood correlates of urban trail use. Journal of Physical Activity and Health, 3, S139-S157.

Krizek, K. J. and Johnson, P. J. (2006). Proximity to trails and retail: Effects on urban cycling and walking. Journal of the American Planning Association, 72(1), 33-42.

Monday 4/20 Lindsey, G., Wilson, J., Rubchinskaya, E., Yang, J. and Han, Y. (2007). Estimating urban trail traffic: Methods for existing and proposed trails. Landscape and Urban Planning 81, 299-315.

Lindsey, G. and Nguyen, D. B. L. (2004). Use of greenway trails in Indiana. Journal of Urban Planning and Development, 130(4), 213-217.

Monday 5/4 Trail User Survey Workbook (Rails to Trails Conservancy) http://www.railstotrails.org/resources/documents/resource_docs/UserSurveyMethodology.pdf

Wednesday 5/6 Pedestrian and Bicycle Data Collection in US Communities: User Surveys (pages 93-104). http://drusilla.hsrc.unc.edu/cms/downloads/PBIC_Data_Collection_Case_Studies2005.pdf 


\section{Supplemental Readings}

These readings are not required but will provide useful background information and help you with your project work.

Flink, C A., Olka, K., \& Searns, R. M. (2001). Trails for the Twenty-First Century (2nd ed.). Washington, DC: Island Press

Metro (2004). Green Trails: Guidelines for Environmentally Friendly Trails

http://www.oregonmetro.gov/index.cfm/go/by.web/id=11897

Olmsted Brothers (1903). Report of the Park Board

http://www.portlandonline.com/shared/cfm/image.cfm?id=93613

Oregon State Parks (2005). Oregon Trails 2005-2014: Non-Motorized Trails Plan

http://www.oregon.gov/OPRD/PLANS/docs/trails/NonMotorized.pdf

Portland Parks and Recreation (1992). Springwater Corridor Master Plan

Portland Bureau of Planning (1987). Willamette Greenway Plan

Rails to Trails Conservancy (2008). Active Transportation for America

http://www.railstotrails.org/whatwedo/trailadvocacy/ATFA/index.html

Tualatin Hills Parks and Recreation District (2006). Trails Plan

http://www.thprd.org/pdfs/administration/trails2006.pdf 


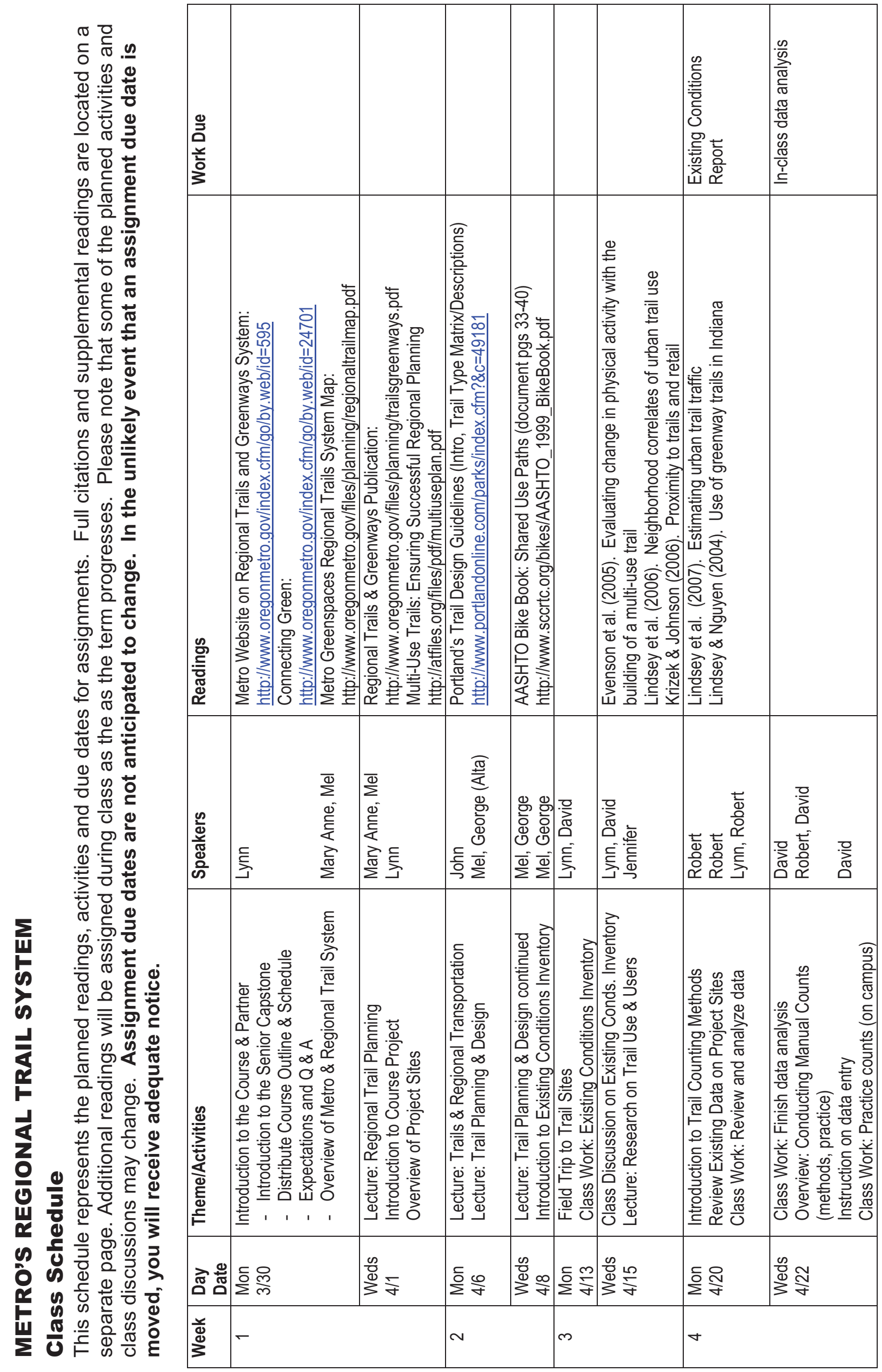




\begin{tabular}{|c|c|c|c|c|c|c|c|c|c|c|c|c|}
\hline & & 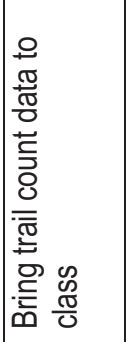 & 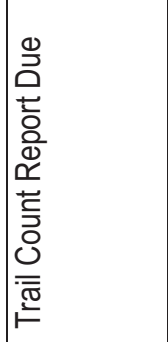 & & & & 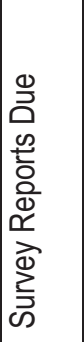 & & 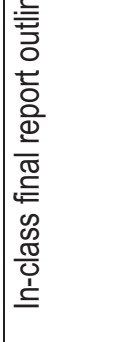 & 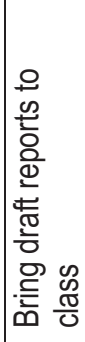 & 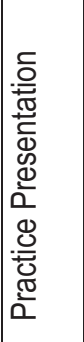 & 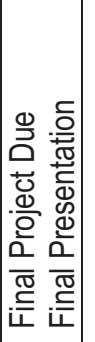 \\
\hline & & 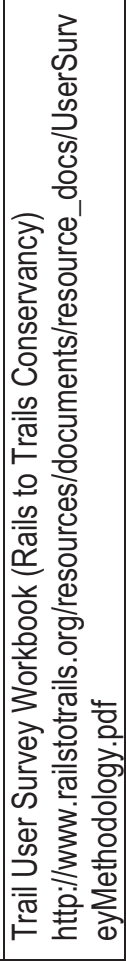 & 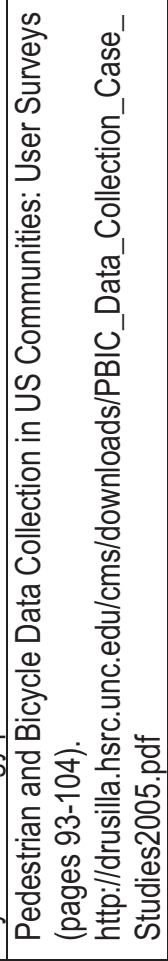 & & & & & & 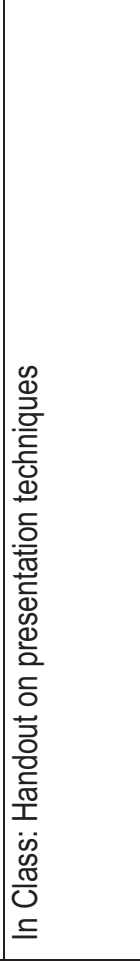 & & & \\
\hline & 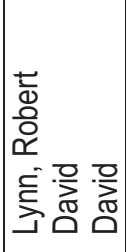 & 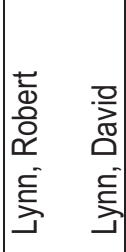 & 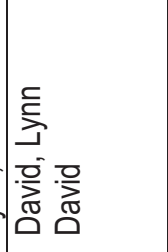 & & 昙 & 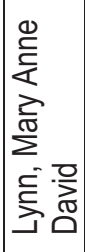 & ફે & & ફ્ & ફ્ & $\overline{\bar{\alpha}}$ & $\overline{\bar{\alpha}}$ \\
\hline 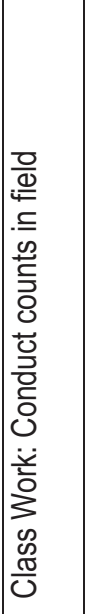 & 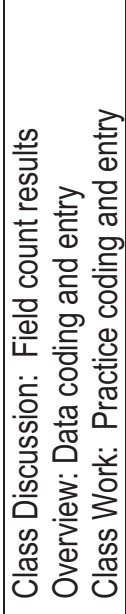 & 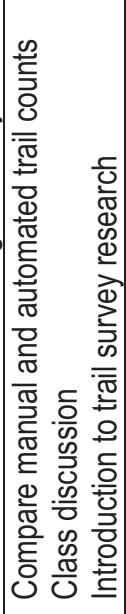 & 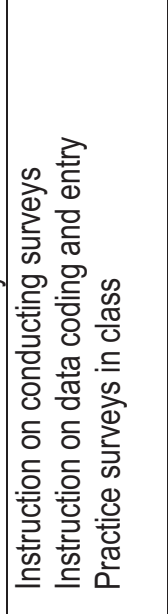 & 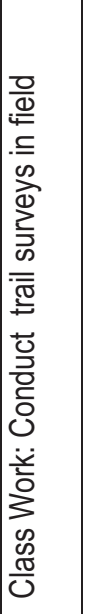 & 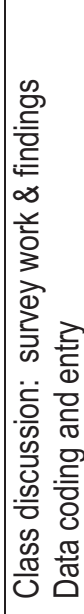 & 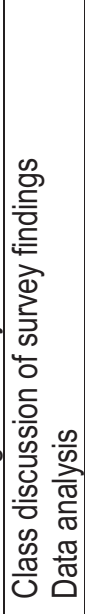 & 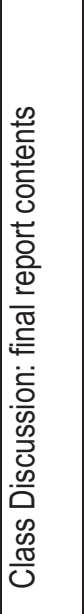 & 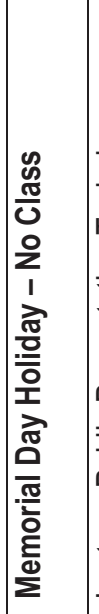 & 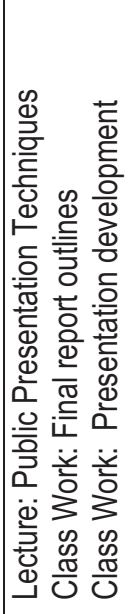 & 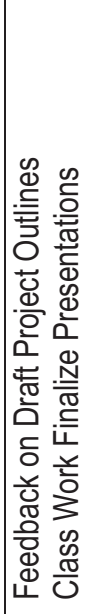 & 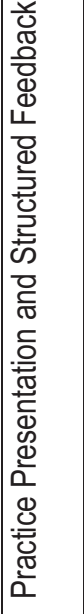 & 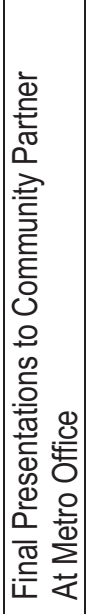 \\
\hline 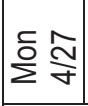 & 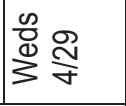 & $\stackrel{\circ}{2} \frac{t}{5}$ & $\frac{0}{0}$ & $\sum_{i}^{\circ}=$ & 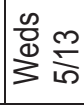 & $\sum^{0} \frac{\infty}{i}$ & 离 & 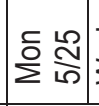 & 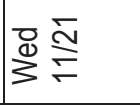 & $\frac{\overline{0}}{\Sigma} \frac{\delta}{0}$ & $\stackrel{0}{0} \frac{m}{0}$ & $\stackrel{\circ}{\Sigma} \stackrel{\infty}{6}$ \\
\hline תما & & 0 & & N & & $\infty$ & & (') & & 음 & & 离 \\
\hline
\end{tabular}




\section{METRO'S REGIONAL TRAIL SYSTEM \\ Senior Capstone • Spring 2009 \\ UNST 421/Section 527}

\section{EXISTING CONDITIONS REPORT}

The existing conditions report is intended to document the conditions on and near your assigned trial segments. To complete this assignment, you should undertake the following tasks:

Tasks:

1. Visit both trail segments as a team.

2. Observe the conditions and complete a separate trail inventory form for each segment.

3. Make additional notes about the conditions and features of each trail segment.

4. Document each trail segment using a digital camera.

\section{Assignment:}

Write a separate report for each trail segment. The report should describe each trail segment including:

- location

- $\quad$ key features of the trail itself (surface, conditions, etc.)

- $\quad$ key features of the area to each side of the trail

The report should incorporate photos to illustrate your comments. All photos should have captions that describe what is shown in each photo. A completed, legible inventory form should be attached to each report as an appendix. Each report should be:

- $\quad$ three to five pages long

- double-spaced text

- 12 point type

- One-inch margins

- Cover page with name of trail segment and names of the team members

Due: Monday, April 20, beginning of class 



\section{METRO'S REGIONAL TRAIL SYSTEM \\ Senior Capstone • Spring 2009 \\ UNST 421/Section 527}

\section{TRAIL USER COUNT REPORT}

The trail user count report is intended to document the number and types of users on the trail during your designated counting times

\section{Tasks:}

1. Conduct the trail counts on each segment during the designated times and days.

2. Log all trail users on the trail count forms.

3. Enter all trail user data into the Excel spreadsheet provided.

\section{Assignment:}

Write a separate report for each trail segment. The report should describe each trail segment including:

- $\quad$ Day, date and time of each counting period

- For each day and time, provide the following information:

- Total number of users

- Total number of users by mode

- Total number of users by gender

- Total number of users by adult/child

- Mode, split by gender

- Gender, split by mode

- $\quad$ Then, provide all of the above information by direction (northbound, southbound)

- Create graphs to illustrate the data (more information on this in class)

Please note: additional analysis and graphs may be assigned in class.

The report should be divided into segments for each day and date of counts. Formatting should be:

- double-spaced text

- 12 point type

- One-inch margins

- $\quad$ Cover page with name of trail segment and names of the team members

Due: Wednesday, May 6, beginning of class

This will give you time to complete your analysis after the last weekend of counting 



\begin{tabular}{|c|c|c|c|}
\hline \multicolumn{4}{|c|}{ Trail Inventory Form } \\
\hline Location: & Name: & & \\
\hline \multicolumn{4}{|c|}{ LINE DATA } \\
\hline FEATURE & ATTRIBUTE & DETAILS & ID \# \\
\hline Path & $\begin{array}{l}\text { Materials (circle one): Concrete, Asphalt, } \\
\text { Boardwalk, Gravel, Brick, Bark Chips, Dirt, } \\
\text { Other } \\
\text { Width Estimate: }\end{array}$ & $\begin{array}{l}\text { Condition (circle one): Good, } \\
\text { Repair, Replace } \\
\text { Description: }\end{array}$ & \\
\hline $\begin{array}{l}\text { Hazardous } \\
\text { Conditions }\end{array}$ & Hazard: & Description: & \\
\hline Fence & $\begin{array}{l}\text { Type (circle one): Wooden, Chain Link, Other } \\
\text { Features (circle all that apply): Hand Rail, } \\
\text { Raised off ground, Art, Other }\end{array}$ & $\begin{array}{l}\text { Condition (circle one): Good, } \\
\text { Repair, Replace } \\
\text { Description: }\end{array}$ & \\
\hline \multicolumn{4}{|c|}{ POINT DATA } \\
\hline Lights & $\begin{array}{l}\text { Type (circle one): Twin ornamental, Single } \\
\text { Ornamental, Non-ornamental }\end{array}$ & $\begin{array}{l}\text { Condition (circle one): Good, } \\
\text { Repair, Replace } \\
\text { Description: }\end{array}$ & \\
\hline Seating & Type: Bench, Chair, Picnic Table, Other & $\begin{array}{l}\text { Condition (circle one): Good, } \\
\text { Repair, Replace } \\
\text { Description: }\end{array}$ & \\
\hline Bike Rack & $\begin{array}{l}\text { Type: Staple, Noodle, Other } \\
\text { Number: }\end{array}$ & $\begin{array}{l}\text { Condition (circle one): Good, } \\
\text { Repair, Replace } \\
\text { Description: }\end{array}$ & \\
\hline Signs & $\begin{array}{l}\text { Type: Trail, Interpretive, Directional, Marker } \\
\text { Mount: Wooden Post, Steel Post, Light Post, } \\
\text { Utility Pole }\end{array}$ & $\begin{array}{l}\text { Condition (circle one): Good, } \\
\text { Repair, Replace }\end{array}$ & \\
\hline
\end{tabular}




\begin{tabular}{|c|c|c|}
\hline & $\begin{array}{l}\text { Type: Trail, Interpretive, Directional, Marker } \\
\text { Mount: Wooden Post, Steel Post, Light Post, } \\
\text { Utility Pole } \\
\text { Type: Trail, Interpretive, Directional, Marker } \\
\text { Mount: Wooden Post, Steel Post, Light Post, } \\
\text { Utility Pole } \\
\text { Type: Trail, Interpretive, Directional, Marker } \\
\text { Mount: Wooden Post, Steel Post, Light Post, } \\
\text { Utility Pole } \\
\text { Type: Trail, Interpretive, Directional, Marker } \\
\text { Mount: Wooden Post, Steel Post, Light Post, } \\
\text { Utility Pole }\end{array}$ & $\begin{array}{l}\text { Condition (circle one): Good, } \\
\text { Repair, Replace } \\
\text { Condition (circle one): Good, } \\
\text { Repair, Replace } \\
\text { Condition (circle one): Good, } \\
\text { Repair, Replace } \\
\text { Condition (circle one): Good, } \\
\text { Repair, Replace }\end{array}$ \\
\hline Signs & $\begin{array}{l}\text { Type: Regulatory, Private Property, No } \\
\text { Trespassing, Other } \\
\text { Mount: Wooden Post, Steel Post, Light Post, } \\
\text { Utility Pole } \\
\text { Type: Regulatory, Private Property, No } \\
\text { Trespassing, Other } \\
\text { Mount: Wooden Post, Steel Post, Light Post, } \\
\text { Utility Pole } \\
\text { Type: Regulatory, Private Property, No } \\
\text { Trespassing, Other } \\
\text { Mount: Wooden Post, Steel Post, Light Post, } \\
\text { Utility Pole } \\
\text { Type: Regulatory, Private Property, No } \\
\text { Trespassing, Other } \\
\text { Mount: Wooden Post, Steel Post, Light Post, } \\
\text { Utility Pole } \\
\text { Type: Regulatory, Private Property, No } \\
\text { Trespassing, Other } \\
\text { Mount: Wooden Post, Steel Post, Light Post, } \\
\text { Utility Pole }\end{array}$ & $\begin{array}{l}\text { Condition (circle one): Good, } \\
\text { Repair, Replace } \\
\text { Condition (circle one): Good, } \\
\text { Repair, Replace } \\
\text { Condition (circle one): Good, } \\
\text { Repair, Replace } \\
\text { Condition (circle one): Good, } \\
\text { Repair, Replace } \\
\text { Condition (circle one): Good, } \\
\text { Repair, Replace }\end{array}$ \\
\hline Restroom & Type (circle one): Structure, Porta-potty, other & $\begin{array}{l}\text { Condition (circle one): Good, } \\
\text { Repair, Replace }\end{array}$ \\
\hline $\begin{array}{l}\text { Water } \\
\text { Fountain }\end{array}$ & Description: & $\begin{array}{l}\text { Condition (circle one): Good, } \\
\text { Repair, Replace }\end{array}$ \\
\hline $\begin{array}{l}\text { Access/Egress } \\
\text { Points }\end{array}$ & $\begin{array}{l}\text { Mode (circle all that apply): Bike, Pedestrian, } \\
\text { Boat, Automobile, Horse } \\
\text { Description: } \\
\text { Mode (circle all that apply): Bike, Pedestrian, } \\
\text { Boat, Automobile, Horse } \\
\text { Description: }\end{array}$ & $\begin{array}{l}\text { Quality (circle one): Good, } \\
\text { fair, poor } \\
\text { Notes: } \\
\text { Quality (circle one): Good, } \\
\text { fair, poor } \\
\text { Notes: }\end{array}$ \\
\hline Other & Description: & Notes: \\
\hline
\end{tabular}


Pathway Count Form (use different form for each 15-minute period)

Name of Data Collector:

Location:

Date:

Time Period:

Weather:

Notes:

\begin{tabular}{|c|c|c|c|c|}
\hline Users & & Northbound & Southbound & Totals \\
\hline \multirow{3}{*}{ Bicyclists } & Male & & & \\
\hline & Female & & & \\
\hline & Child & & & \\
\hline \multirow{3}{*}{ Pedestrians } & Male & & & \\
\hline & Female & & & \\
\hline & Child & & & \\
\hline \multirow{3}{*}{$\begin{array}{l}\text { Other (scooter, } \\
\text { rollerblade, } \\
\text { wheelchair, etc.) }\end{array}$} & Male & & & \\
\hline & Female & & & \\
\hline & Child & & & \\
\hline \multicolumn{2}{|l|}{ Totals } & & & \\
\hline
\end{tabular}





\section{Instructions for Using the Pathway Count Form}

\section{Instructions:}

Arrive at count location at least $\mathbf{1 5}$ minutes before the count time to prepare all eight (8) count forms as follows:

\begin{tabular}{|l|l|}
\hline 1$)$ & $\begin{array}{l}\text { Fill in your name, the location where you are counting, the date and } \\
\text { time. Because you will be recording } 15 \text { minutes-worth of information per } \\
\text { form, clearly label the time period represented by each form. Weather } \\
\text { information can be general. Note if it's cool, cold, warm, hot, sunny, } \\
\text { raining, overcast... }\end{array}$ \\
& $\begin{array}{l}\text { Note anything unusual you observe. For example, nearby construction } \\
\text { that might impact path users or lots of conflicts between bikes and } \\
\text { pedestrians on the paths. }\end{array}$ \\
\hline 2$)$ & $\begin{array}{l}\text { Count each pedestrian, cyclist, wheelchair user, or other user passing } \\
\text { through the path or intersection by making tick-marks in the tally boxes } \\
\text { for mode and gender. Begin counts precisely at the beginning of the 15- } \\
\text { minute period and end promptly at the end of the 15-minute period. }\end{array}$ \\
After the end of each 15-minute period, begin a new form (remember: \\
you set up all eight blank forms before the count!) and count the next \\
15-minute's pathway users
\end{tabular}

\section{Counting Tips:}

- Pick a point at your count location that users must pass before you'll record their information. Make tally marks on the sheet only after pathway users have passed this point (i.e. do not mark them in advance anticipating that they will continue forward).

- If working in teams, and especially on busy pathways, one person can record the directional information and another can record the gender and mode information on a separate form. Transfer the gender/mode information to the count form after the 2-hour count.

- Do not try to tally count information after each 15-minute period. Do it following the complete count. 



\section{TRAIL USE SURVEY}

To be completed by Data Collector:

Name of Data Collector:

Location:

Date:

Time Period:

Weather:

Notes:

To be completed by Trail User: Responses are confidential and will be used to improve conditions here and on other similar facilities.

1. What best describes why you are out here today?
a. For pleasure/exercising
b. Going to/from work or school
c. Shopping, doing errands, visiting friends
d. Other:

2. Who else is using the trail with you today?

$\square$ a. I am alone

b. I am with children

c. I am with adult family/friends

3. Which trail access point did you use today?

4. How did you get to the trail today?
$\square \quad$ a. Drove
$\square$ b. Walked or biked
$\square$ c. Transit

5. What are you doing on the trail right now?
$\square \quad$ a. Walking
$\square \quad$ b. Biking
$\square$ c. Other:

6. Why are you using this trail as opposed to walking/riding elsewhere? Check all that apply.
$\square \quad$ a. Accessible/close
b. Direct/good connections
c. Safer than using roads
d. Scenic qualities
e. Flat
f. Length
g. Other:

7. What would you like to see improved? Check all that apply.
a. Make it longer
b. Better access
c. More parking: car ___ a bike
d. Add drinking fountains
e. Add restrooms
f. Lower bike speeds
g. Fewer pedestrians
h. Better surface
i. Better safety
j. Other:

8. Where did you start this trip?

9. Where will you end this trip?

10. How often, on average, do you use the trail?
a. Daily
b. 3-6 days per week
c. 1-2 days per week
d. 1-3 days per month
e. Less than once a month
f. First time. If so, skip to Question 12

11. Is this pretty constant all four seasons of the year?
$\square \quad$ a. Yes. If no, what seasons do you come here?
$\square$ b. Summer
$\square$ c. Fall
$\square$ d. Winter
$\square \quad$ e. Spring

12. Which of the following best describes you?
$\square \quad$ a. I live near this trail
$\square$ b. I work near this trail
$\square$ c. I live somewhere else in the Portland region
d. I live outside the Portland region

13. What is your age?

14. Gender
a. Female
b. Male 



\section{Instructions for Using the Pathway Survey Form}

Try to complete 50 survey forms:

1) Fill in information that best describes the location where you will be surveying (typically names of intersecting paths or streets). Weather information is general. Note if it's cool, cold, warm, or hot, sunny, raining, overcast...

2) Note anything unusual you observe. For example, nearby construction that might be affecting path users, or lots of conflicts between bikes and pedestrians on the paths.

3) Use sidewalk chalk to draw a sign on the pathway announcing that the survey is in progress. Signs should be drawn 100 to $200 \mathrm{ft}$. in advance of the survey location, in both directions.

Sample sign text: "Trail Survey in Progress."

4) Politely stop bicyclists, pedestrians, and other users. Display your paper survey sign. Say something like:

"Excuse me, l'm a student at Portland State University and we are conducting this survey as part of a class this spring. This will take less than one minute and will be completely confidential."

Ask them the questions and record the answers on a form. Use a new form for each survey completed.

5) Keep track of the number of trail users you approached who refused to be surveyed. Keep a tally in the box below.

6) After surveying for your time period, or completing 50 surveys (whichever happens first), pack up your materials.

\begin{tabular}{|l|c|c|c|}
\hline \multicolumn{4}{|c|}{ Survey Refusal Rate } \\
\hline Bikes & Completed & Refused & Total \\
\hline Pedestrians & & & \\
\hline Other users & & & \\
\hline Total & & & \\
\hline
\end{tabular}

Tips:

- If working in teams, and especially on busy pathways, one person should position herself/himself about a dozen yards up the path from the other person, in order to provide fast-moving cyclists a second chance to stop for the survey.

- Use clipboards, cardstock, or cardboard backing to provide a hard surface on which people can fill out their survey. Having multiple clipboards will allow you to administer multiple surveys at the same time. 



\section{Capstone Midcourse Feedback Summary}

\section{Course name: Metro Regional Trails \\ Instructor name: Lynn Weigand \\ Review Date: 5/4/09 \\ Facilitator: Celine Fitzmaurice}

(1) What about this course is helping you to

* learn the course material

* do your community work

- Presenters/speakers are experienced and interactive

- Presentations support each other and provide continuity

- Provided materials needed to do work

- Clear goals/requirements

- Having George and Mel coming to class is nice. A firsthand, detailed, announcement of what we're helping with

- Giving class time to do field work

- Great accessibility to teacher and assistant

- Useful handouts

- David having Excel sheets for easy data entry. His availability for further explanations

- Good resources for when we have problems (badges, chalks, etc.)

(2) What could be changed to improve the course?

- Increase student/site ratio (counts and surveys)

- Make it easier to work in pairs

- Make course more open-ended to utilize student skills more effectively (2 of 3 agreed, 1 disagreed.) (Celine says: The students commented that they might have liked to design and implement their own research methods as opposed to adopting what Metro already has in place. See first bullet point under \#3 as a suggestion for addressing this.)

- More interaction with Metro staff

- Highlight the most useful readings assignments.

- Cut the readings to those that focus on trail survey/counting. Less of the scientific breakdown without further explanation

- In the description of the course, explain that there is a need for midweek volunteering during daytime hours so students can have a better schedule to work with the group

- Provide some sort of free swag/identifier beyond the badges to help identify us. I.e. a t-shirt with PSU or Metro logo to make it easier 
(3) What specific suggestions do you have to bring about those changes?

- Allot time for a student driven simulation/analysis to compare methods with Metro's methods

- Allow more student creativity 
1. Please tell us how the project helped you understand the concepts of trail planning and use within the region.

2. What elements did you like or find most useful about the project experience?

3. What, if any, elements would you change about the project experience?

4. Please rank the usefulness and relevancy of the project to your learning experience

$\begin{array}{ccccc}\text { Very Useful } & & \text { Neutral } & & \text { Not Useful } \\ 5 & 4 & 3 & 2 & 1\end{array}$

5. Please provide any additional comments on the course content and project experience. 



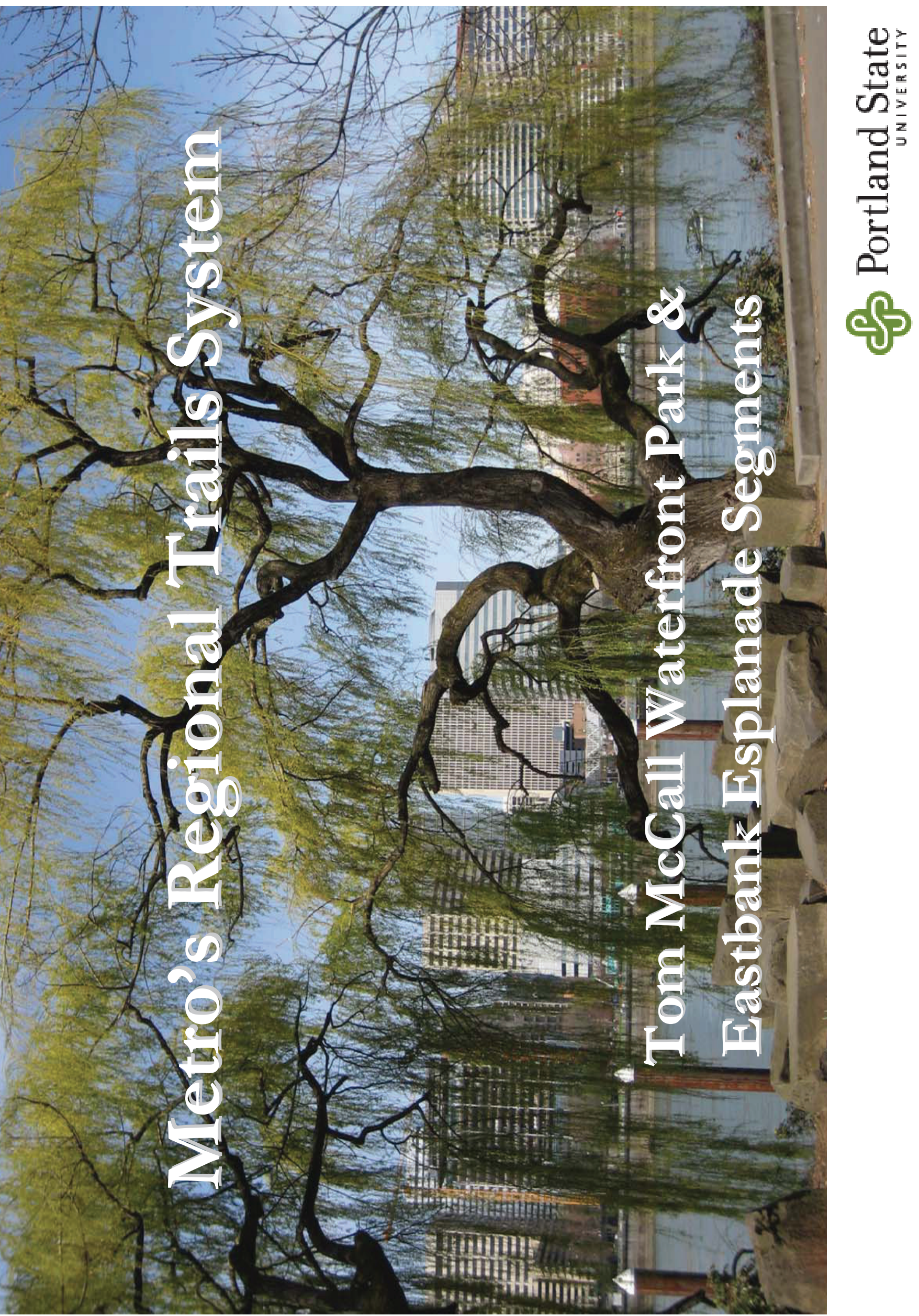




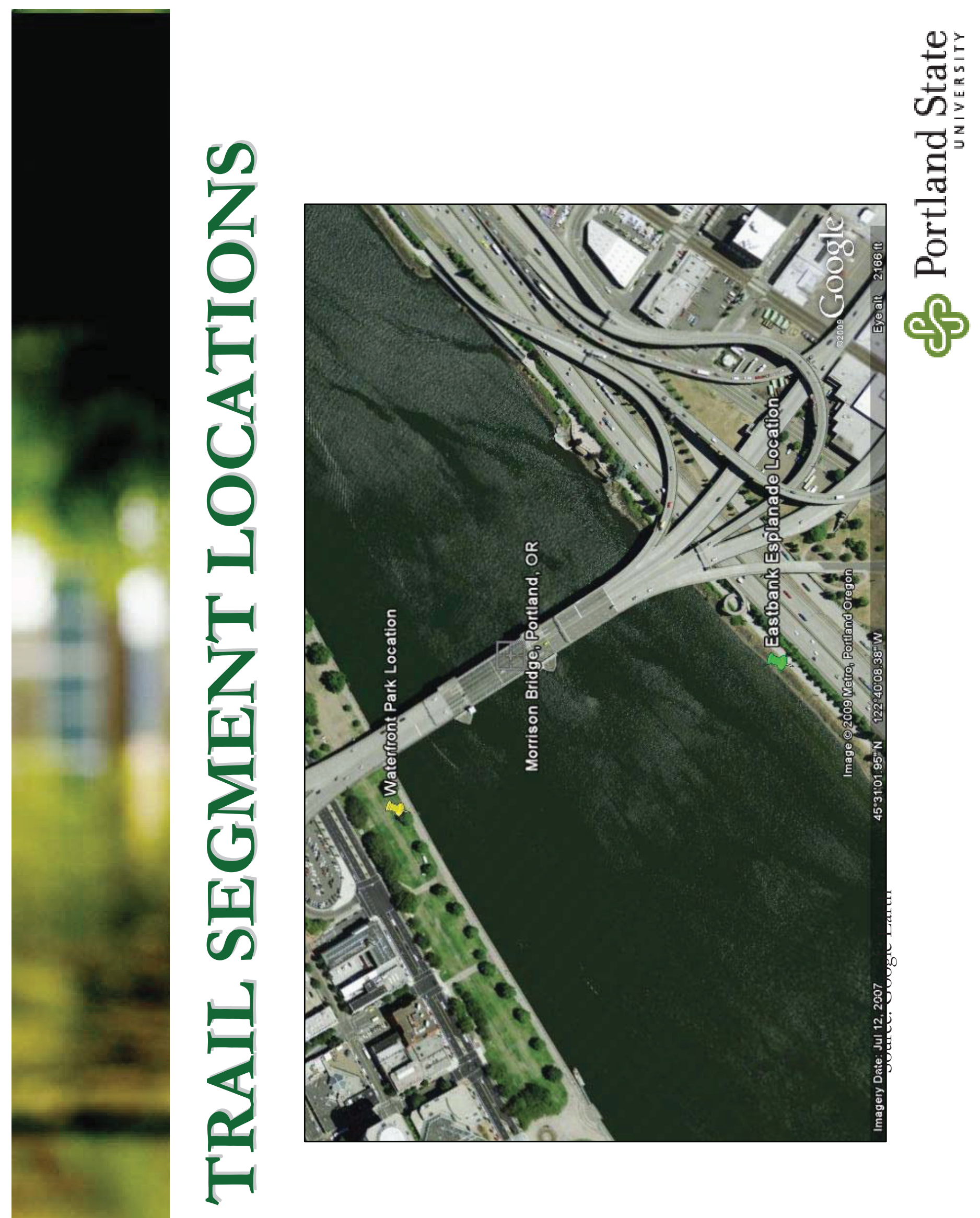



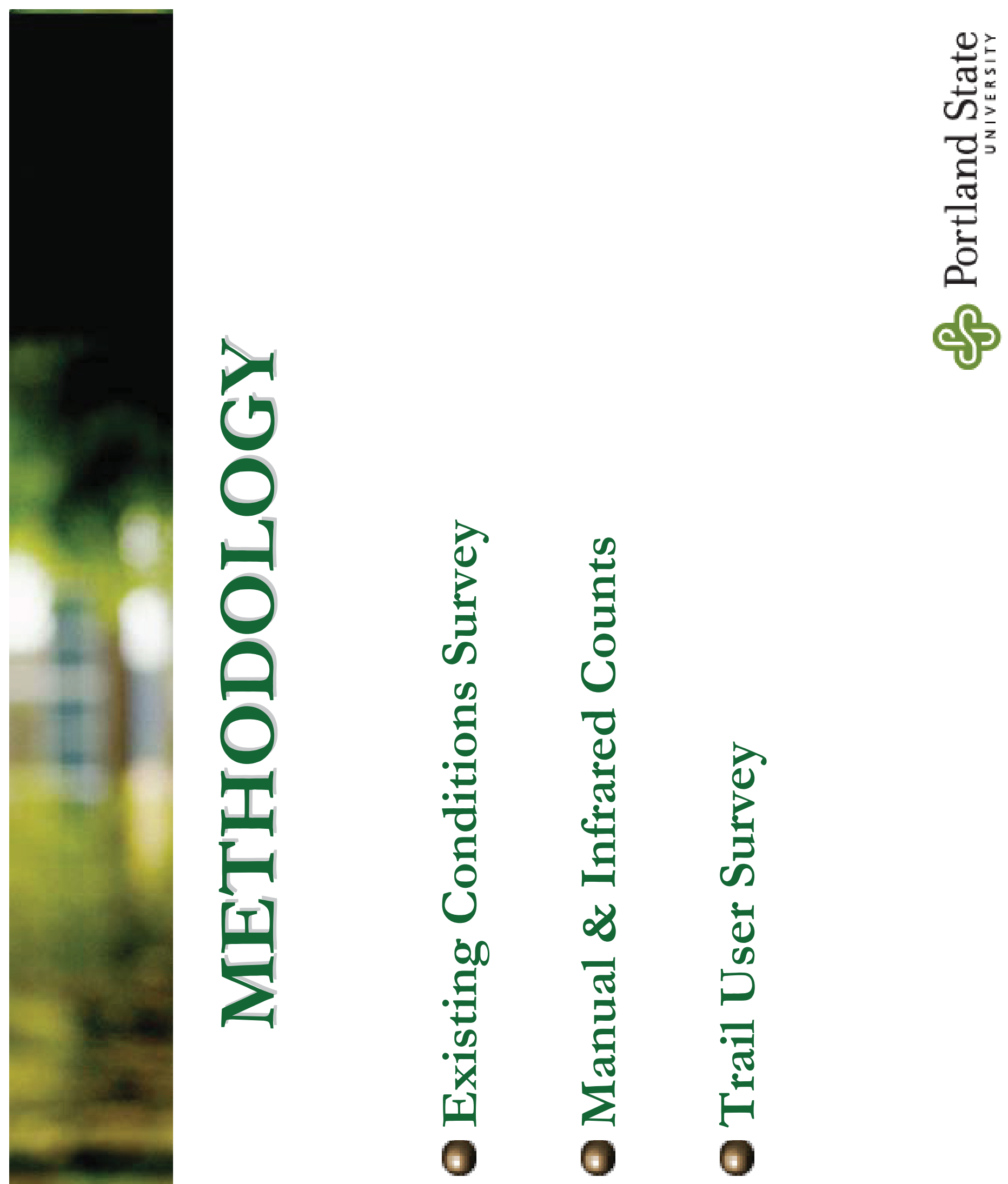

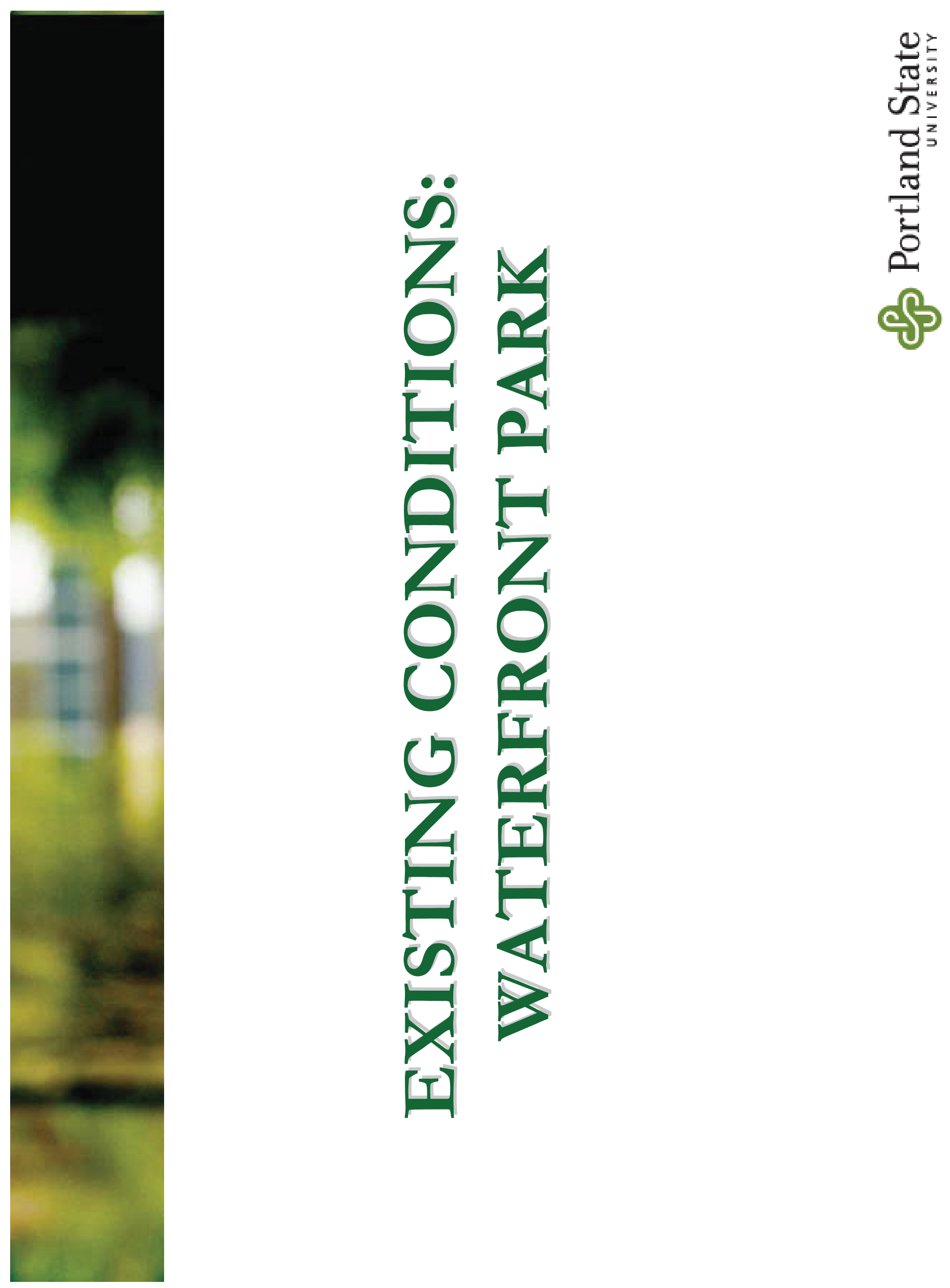


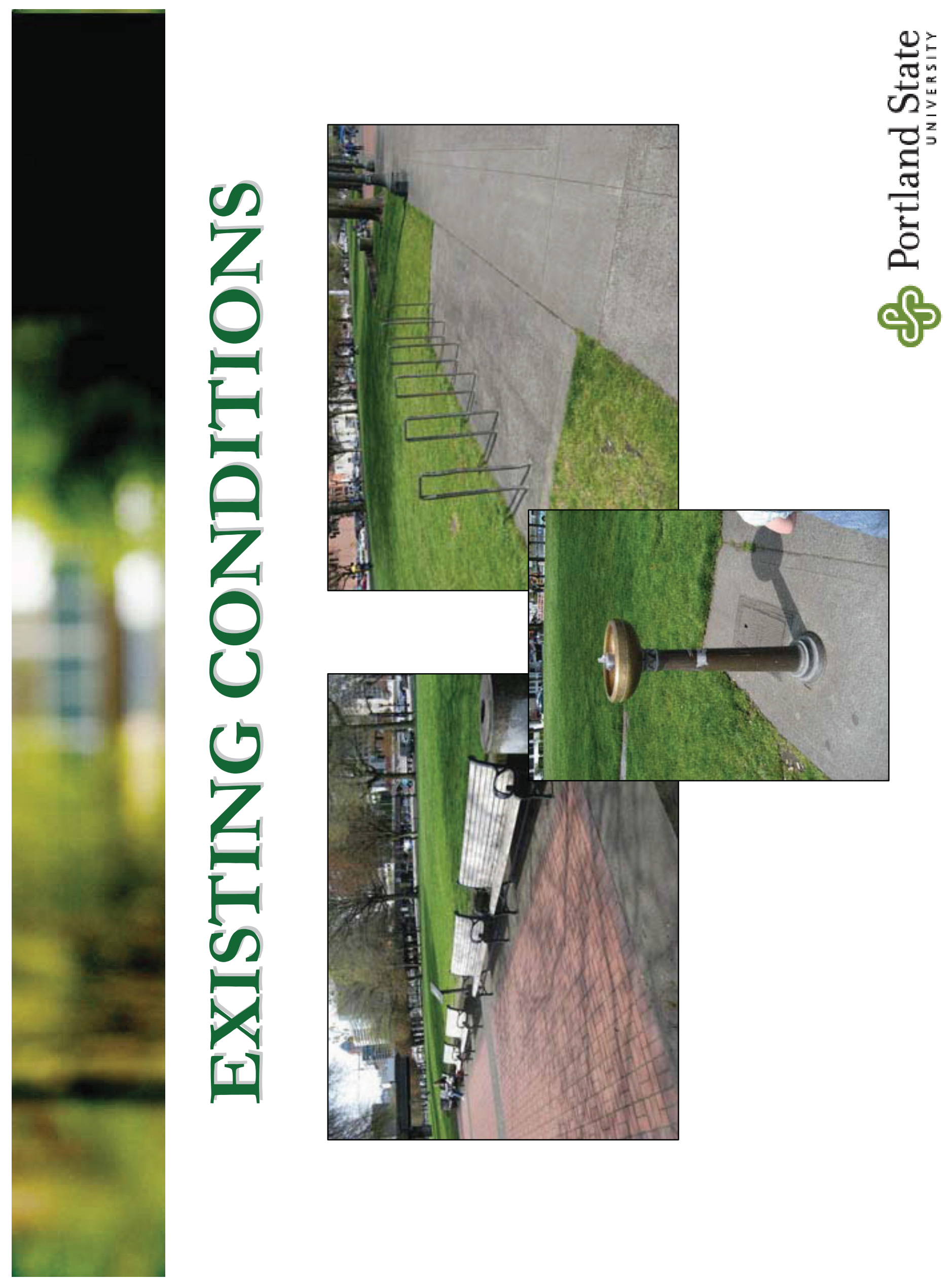




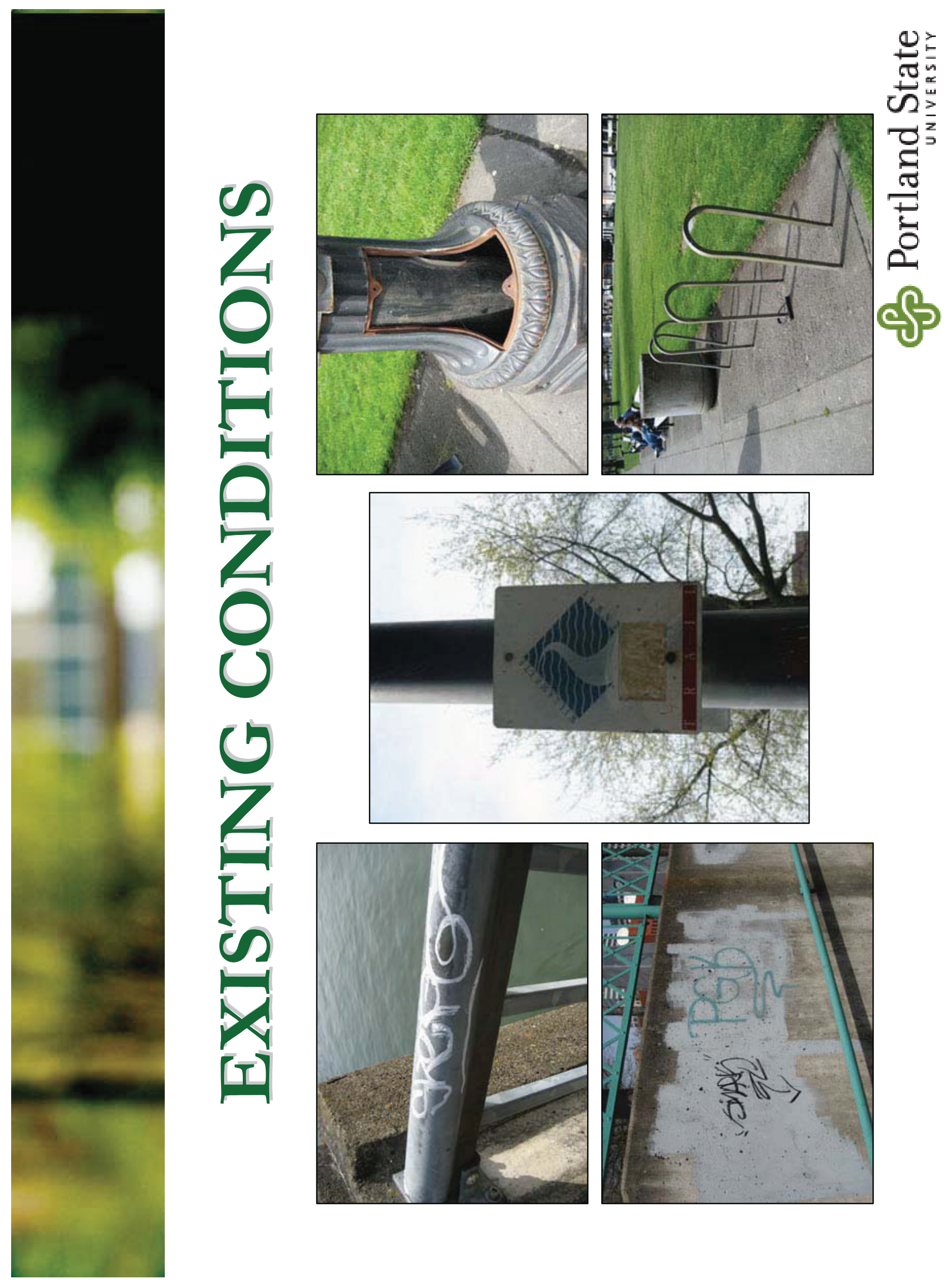




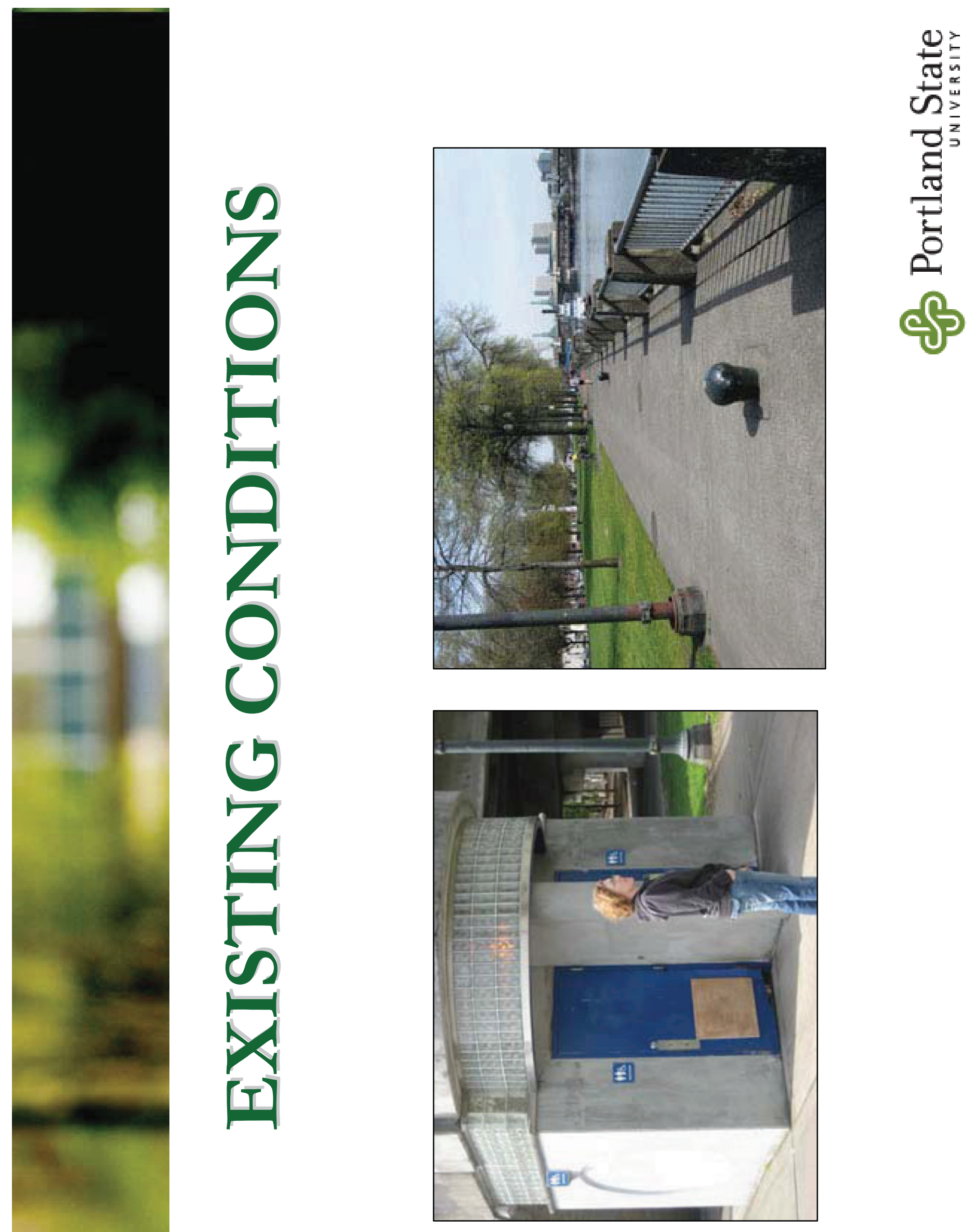



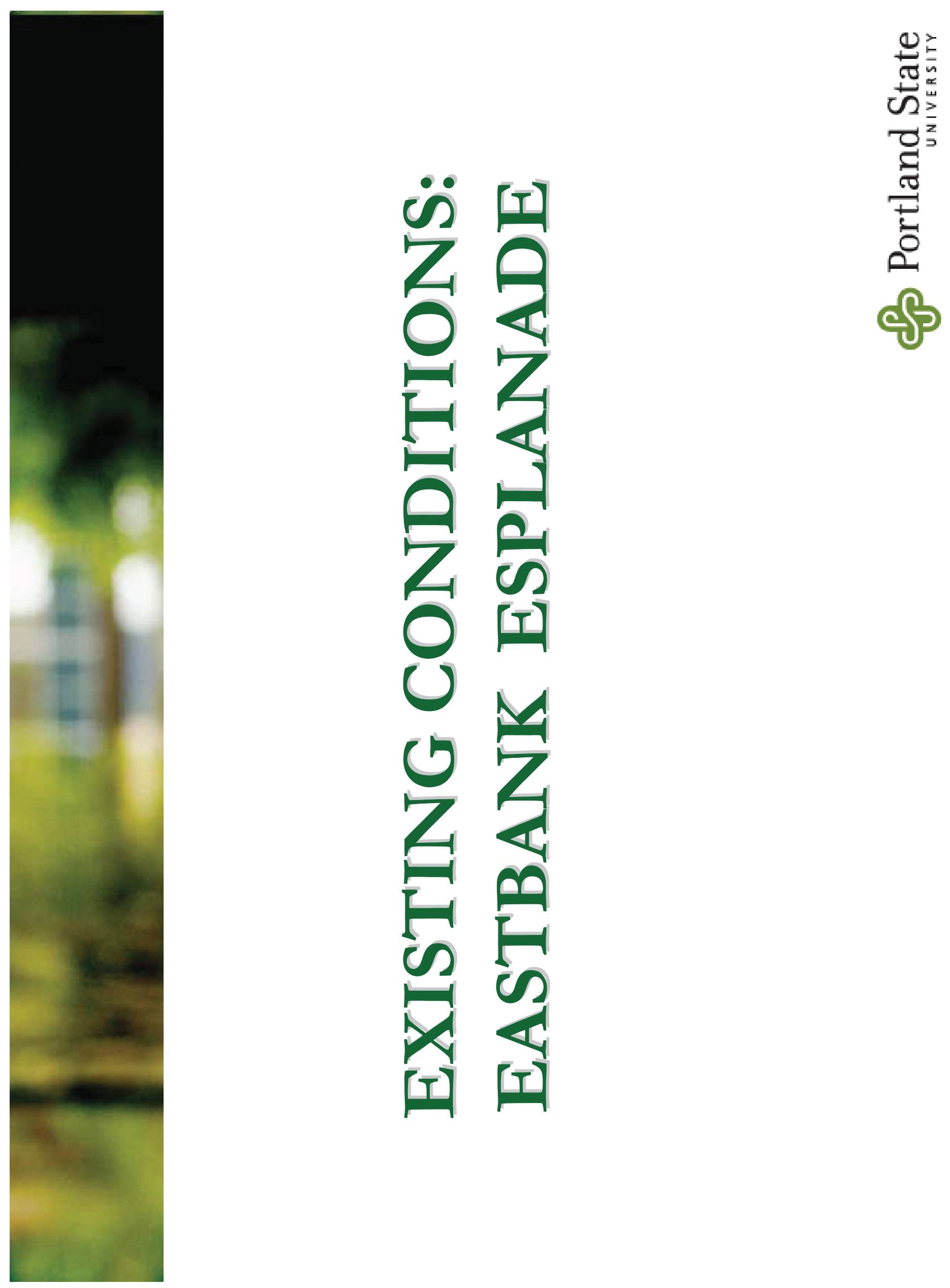


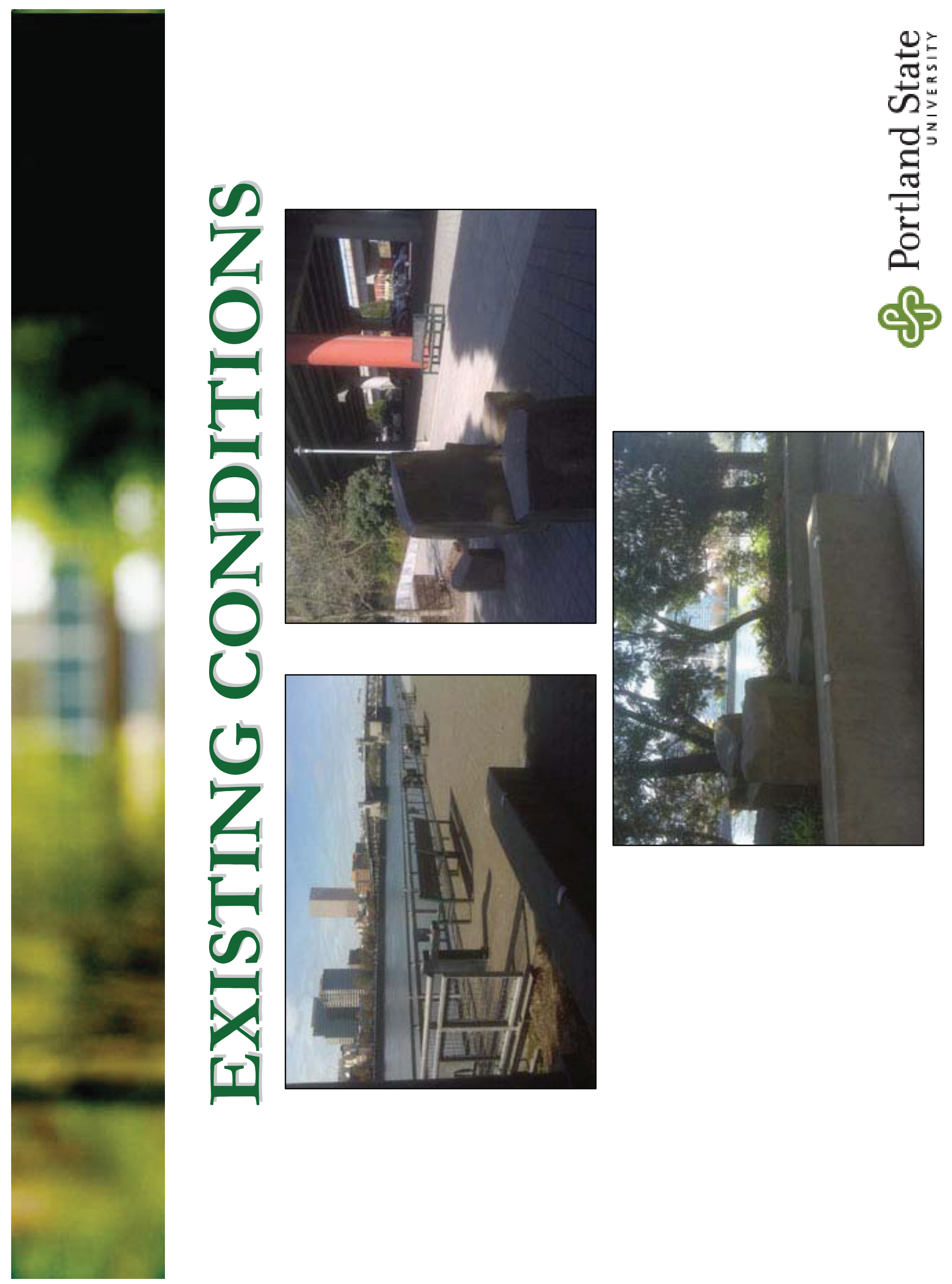



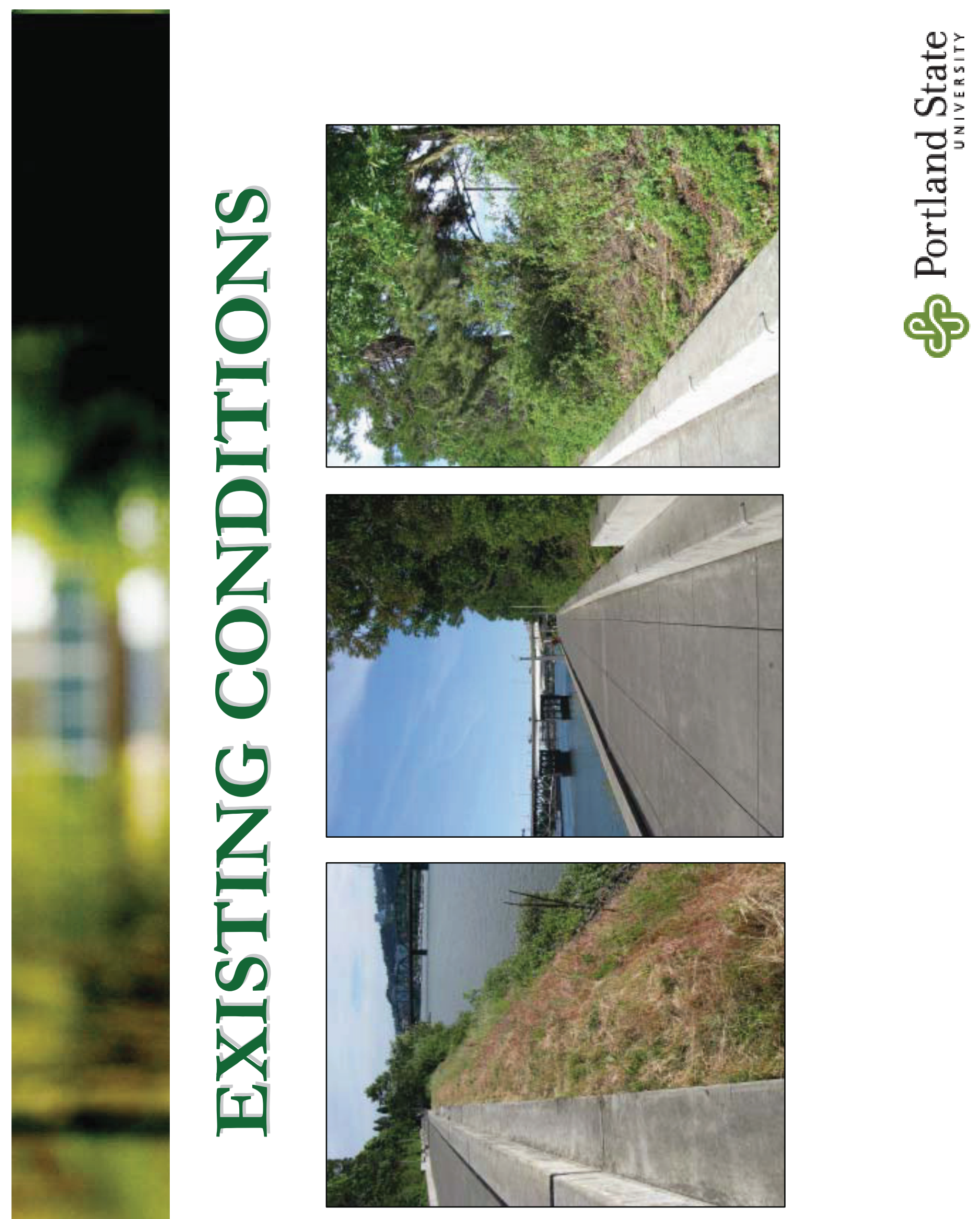


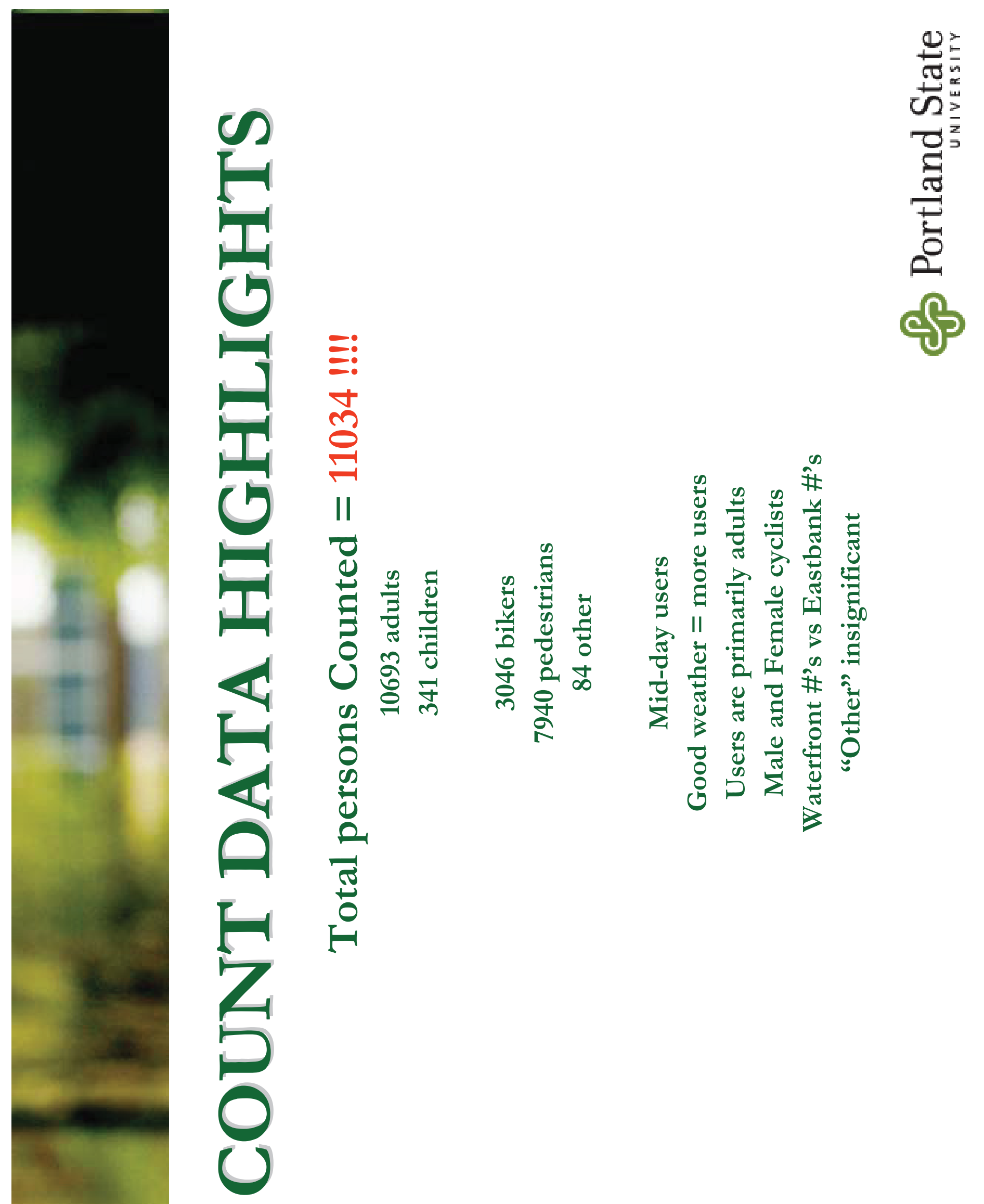



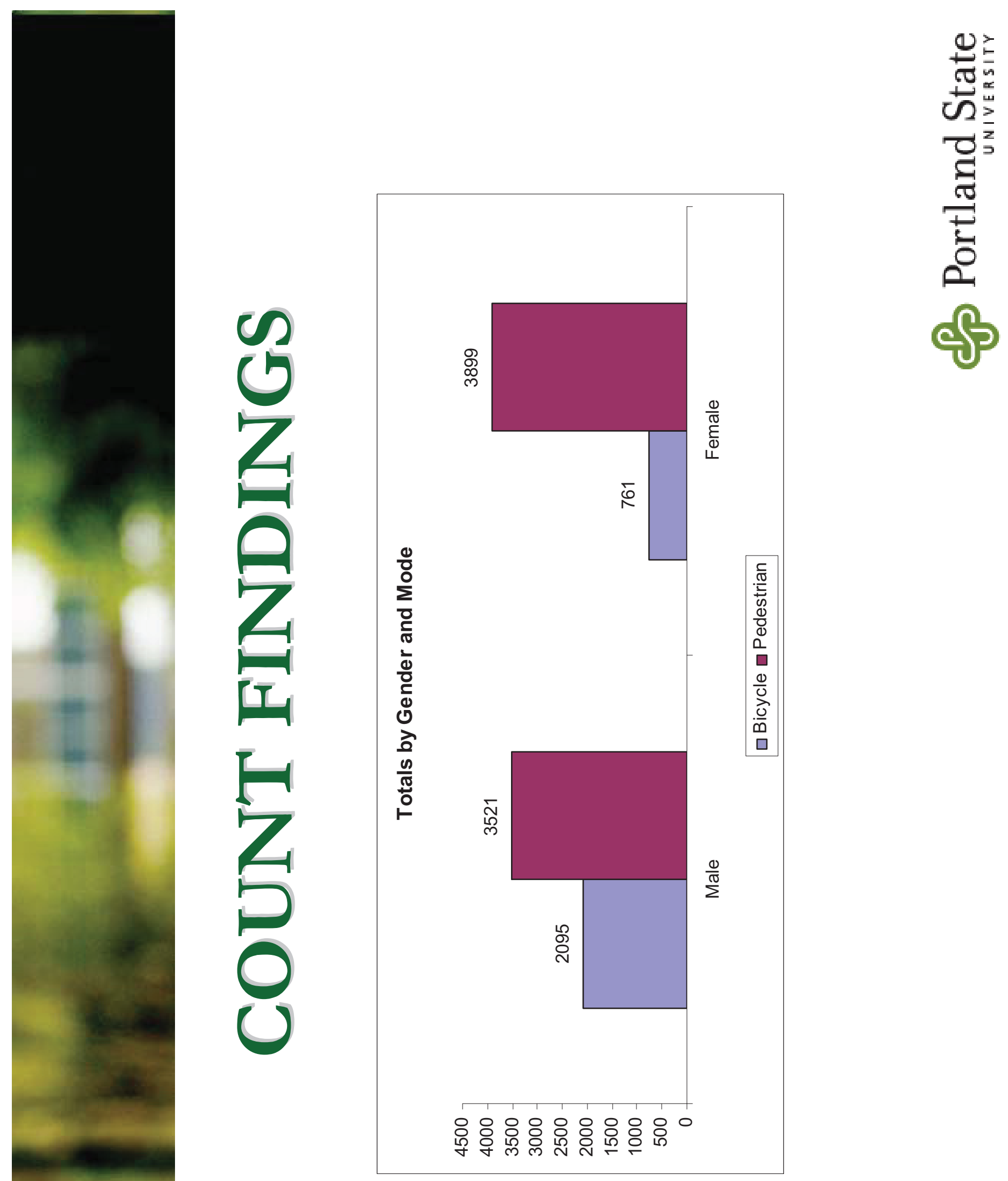


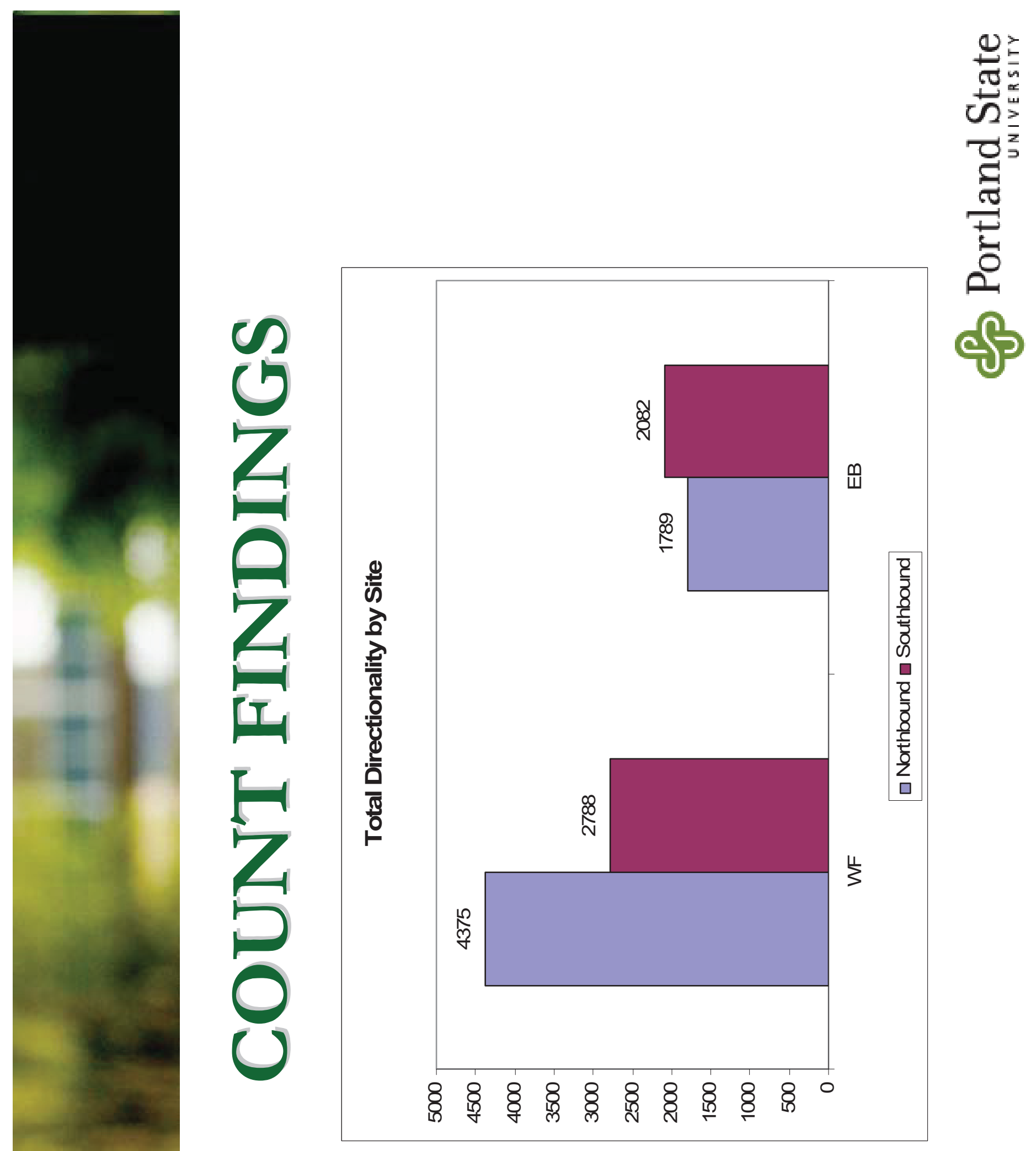




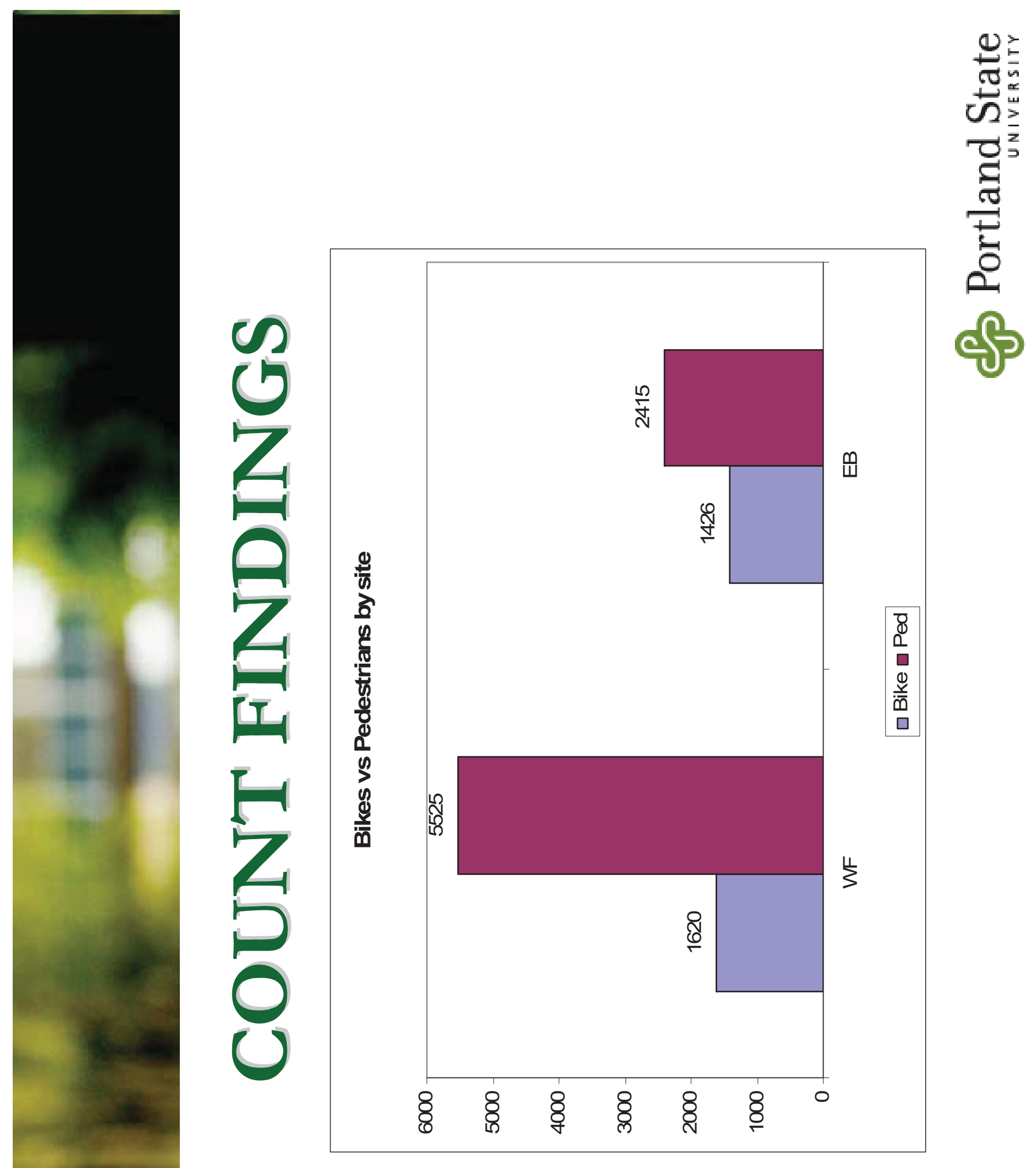




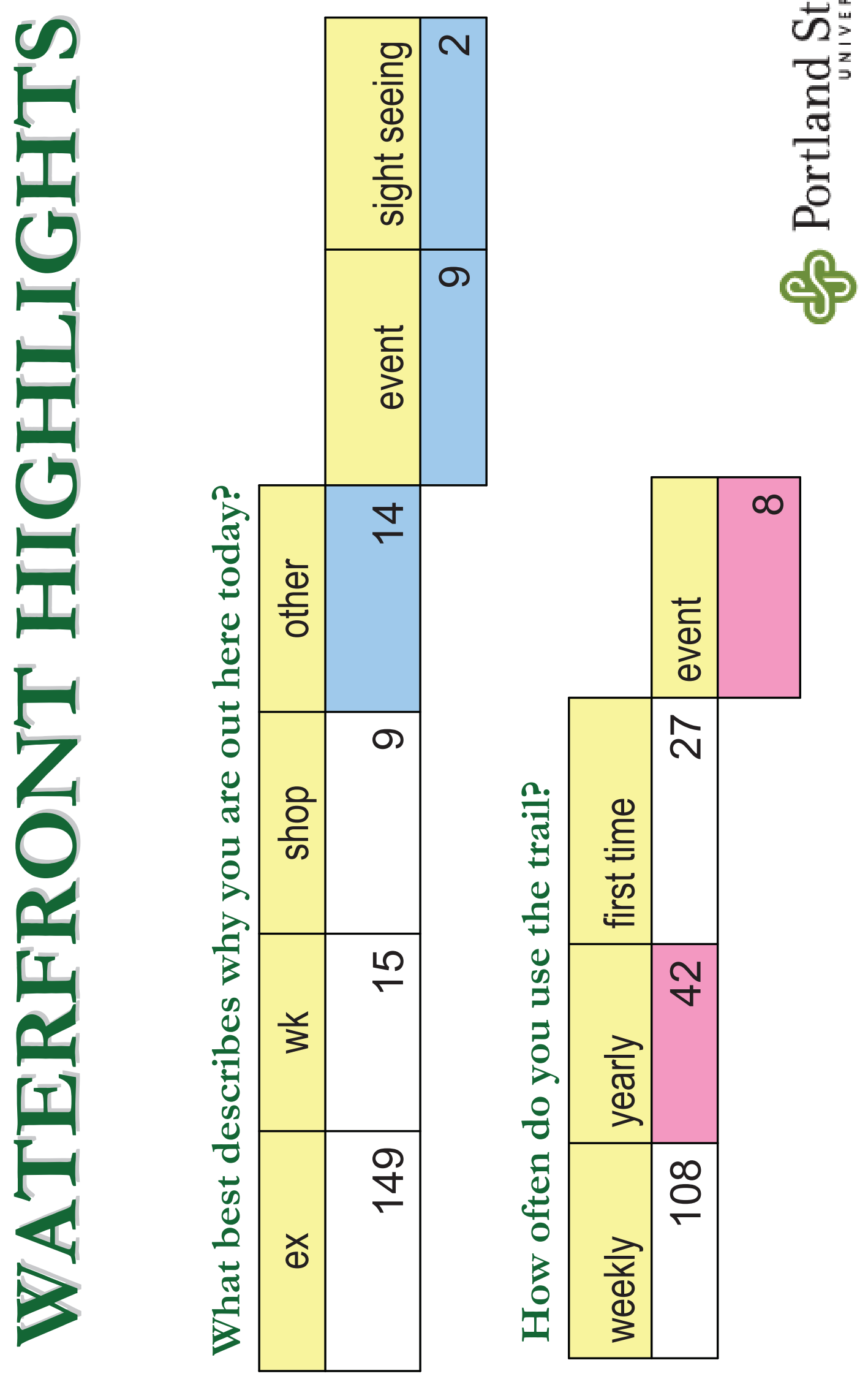




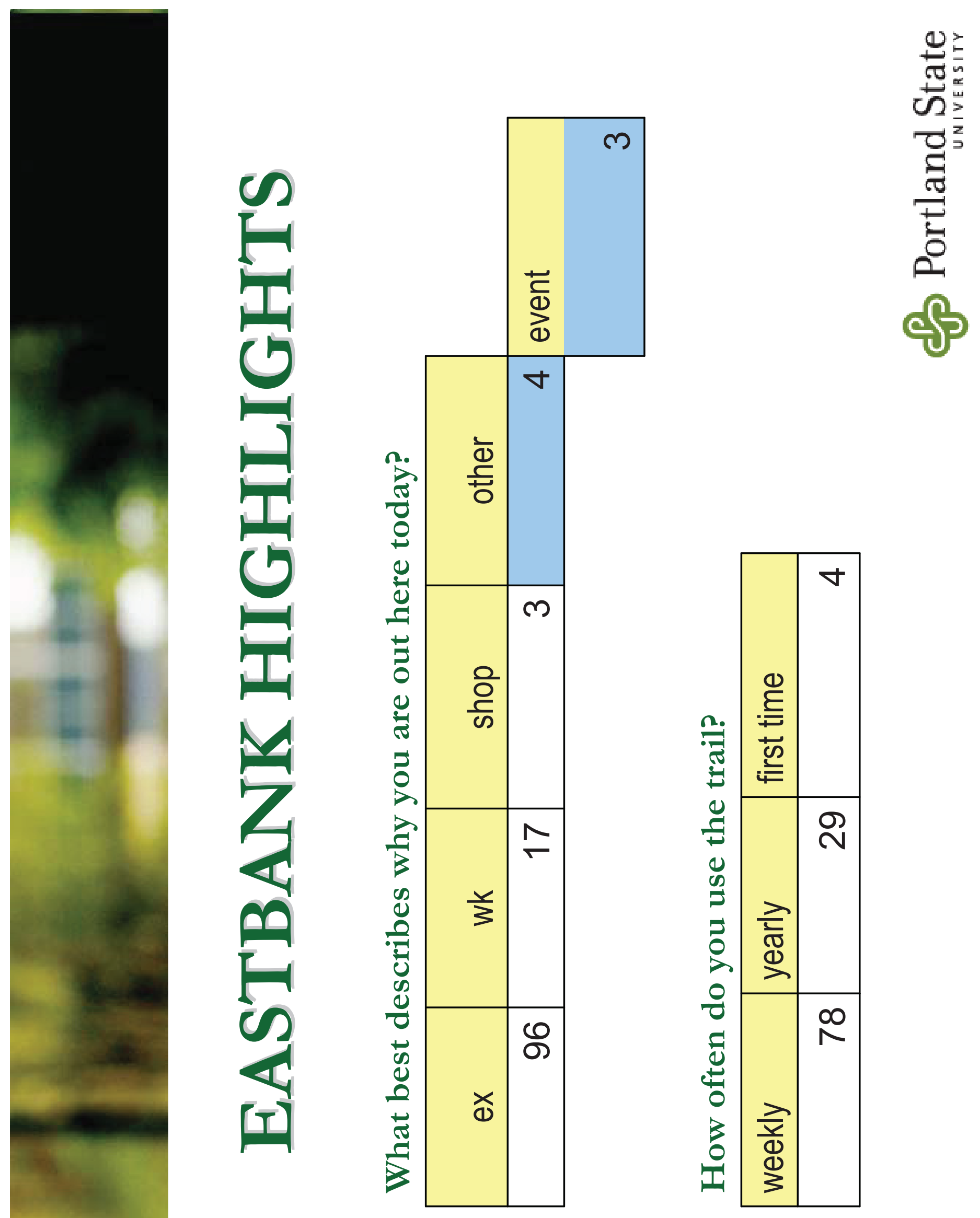




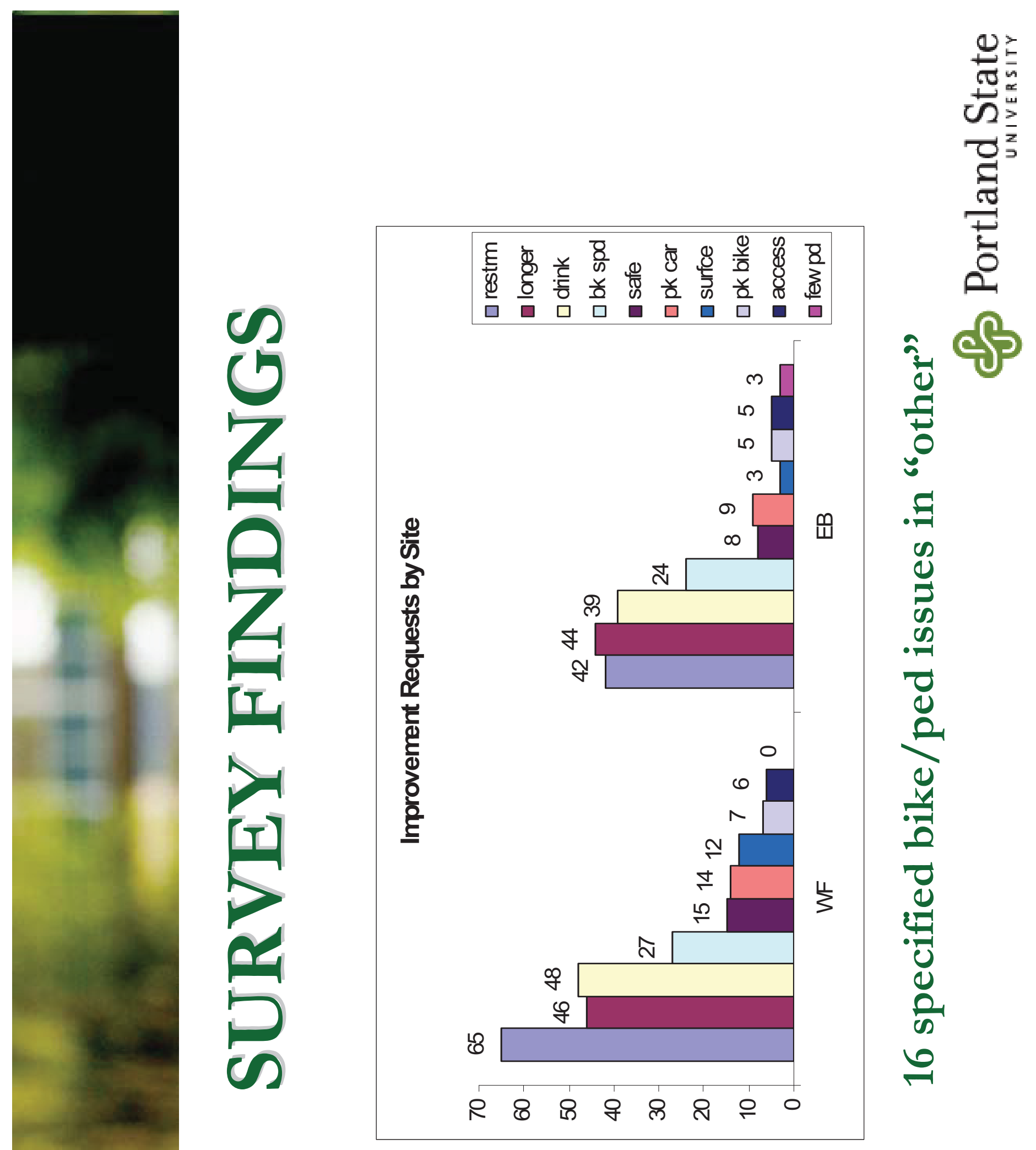



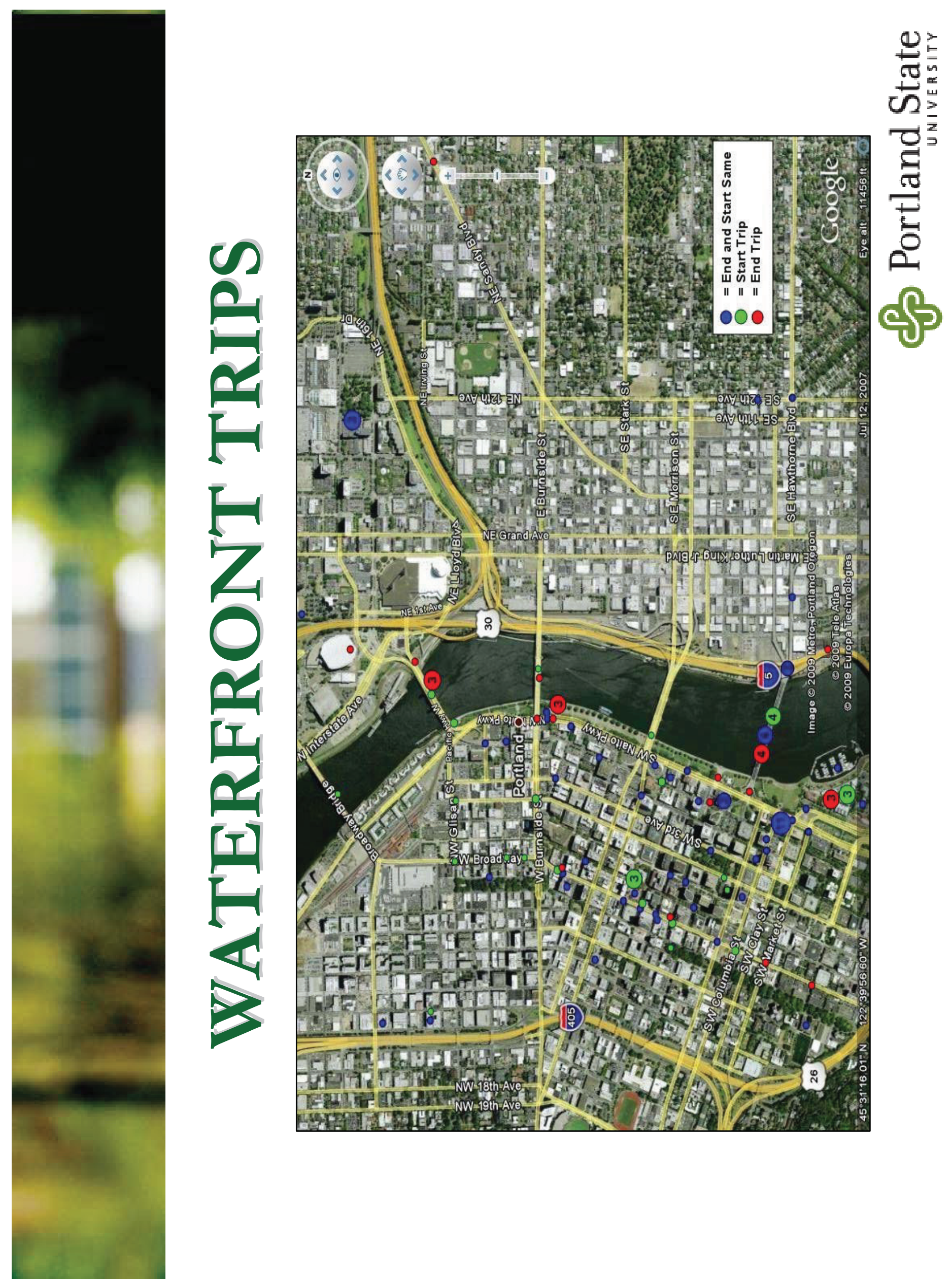

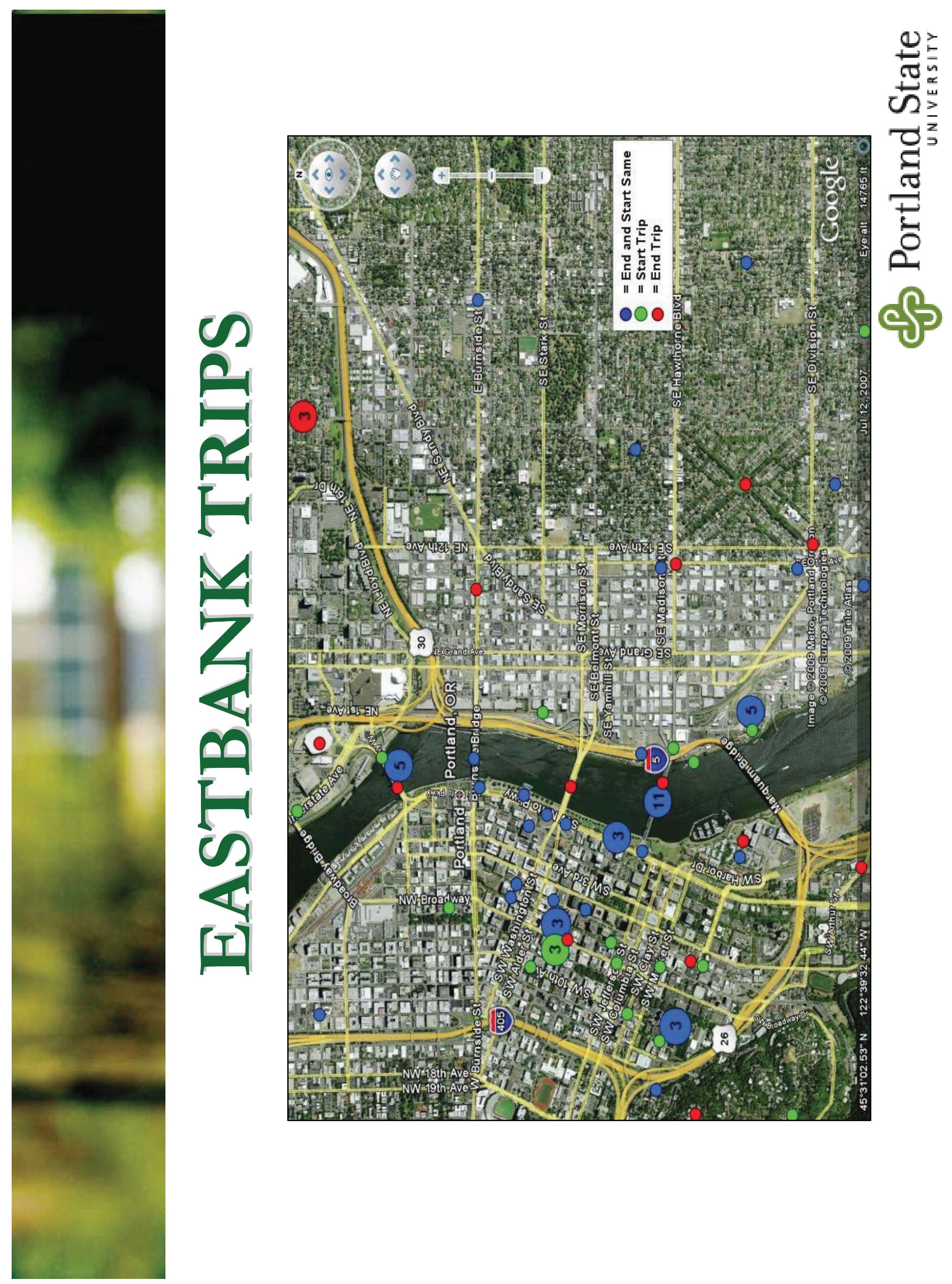

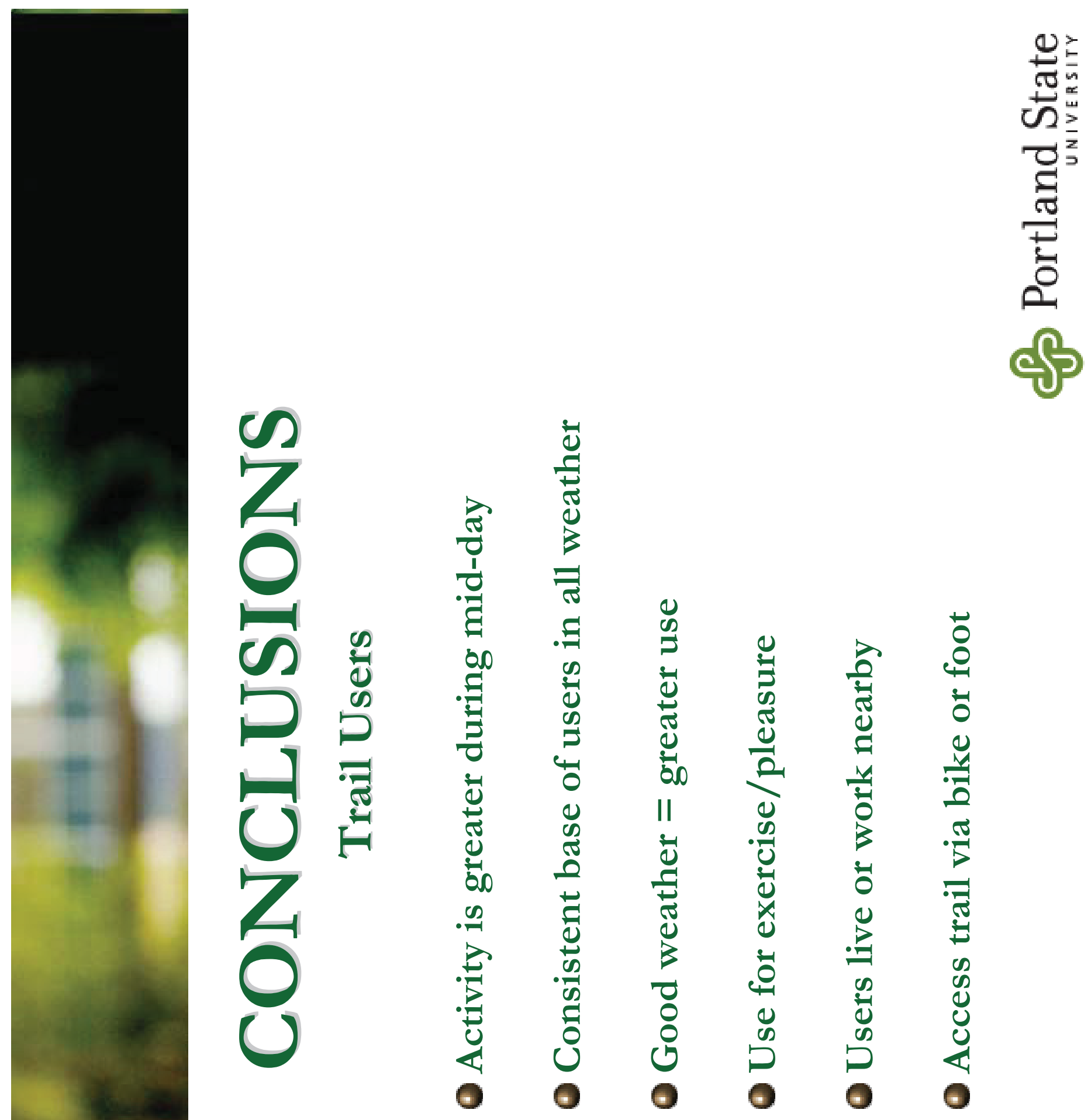


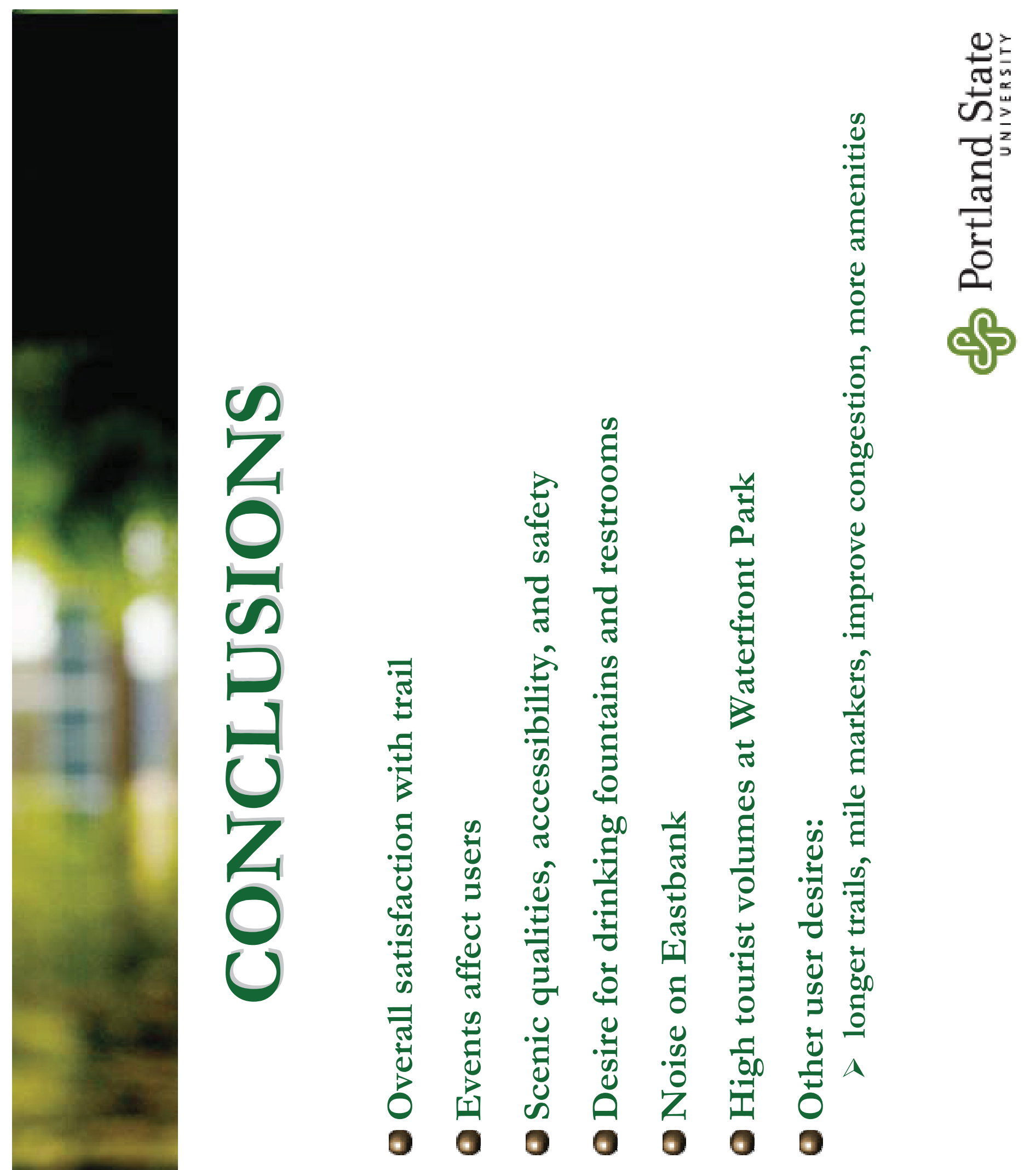



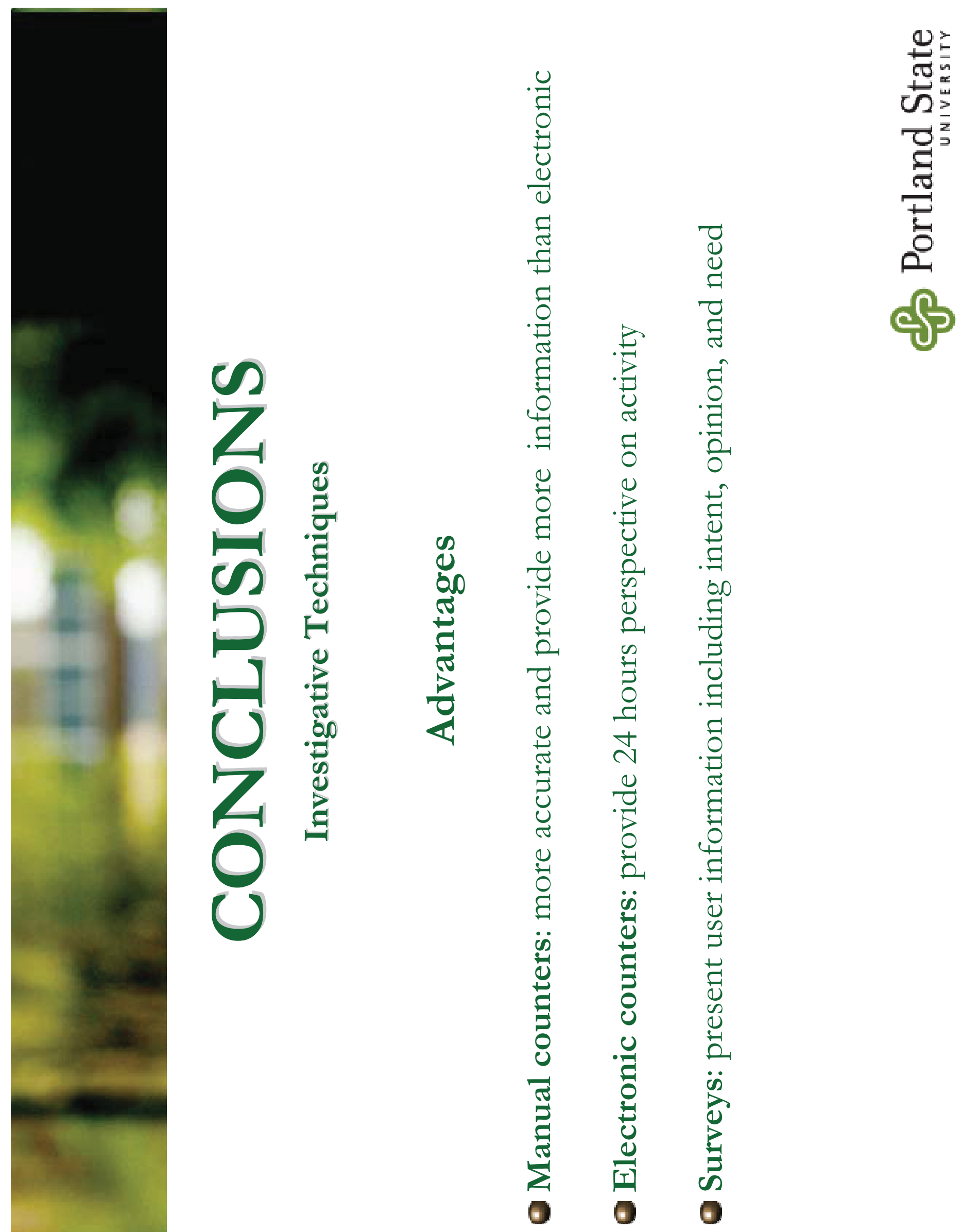


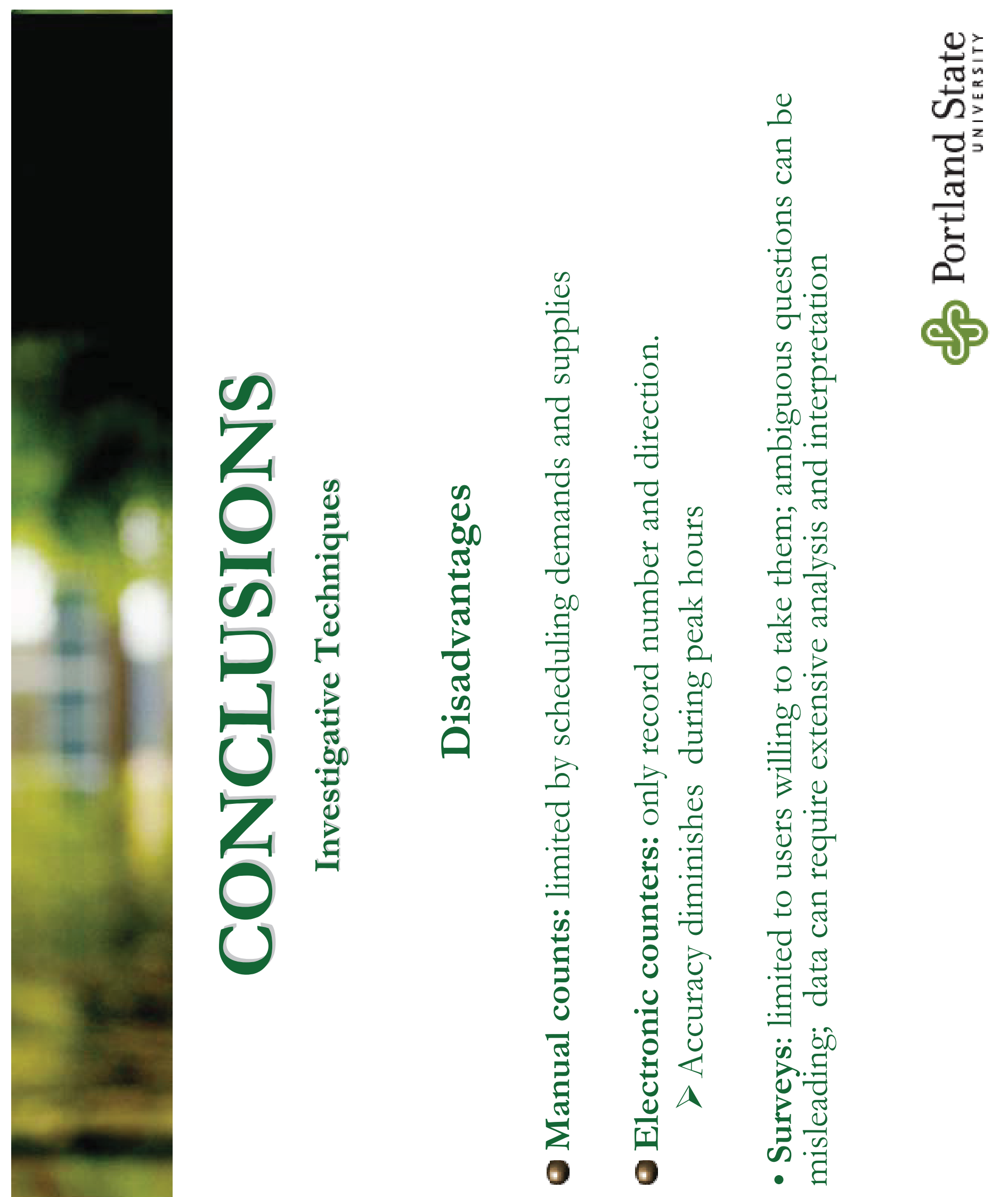



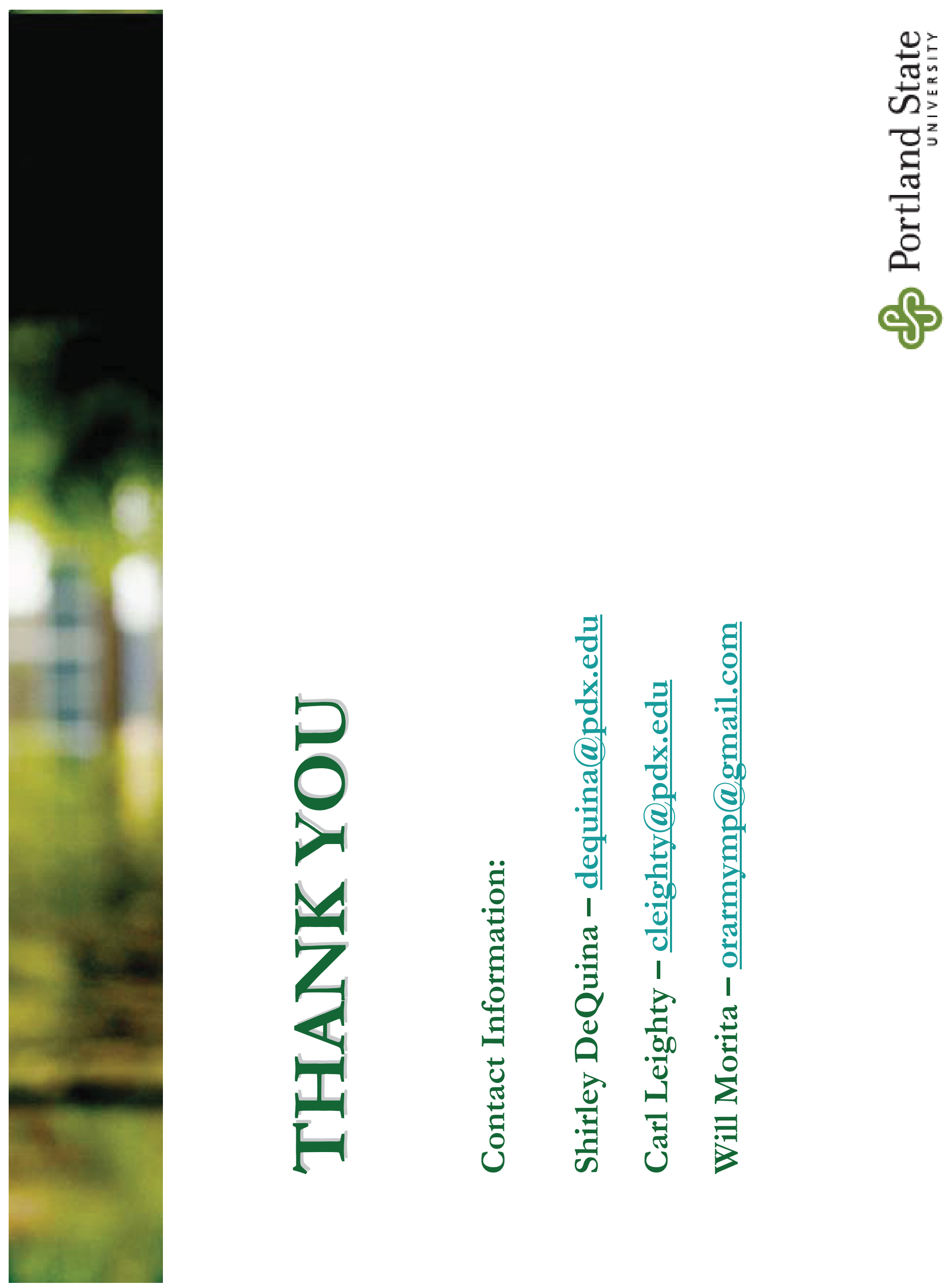


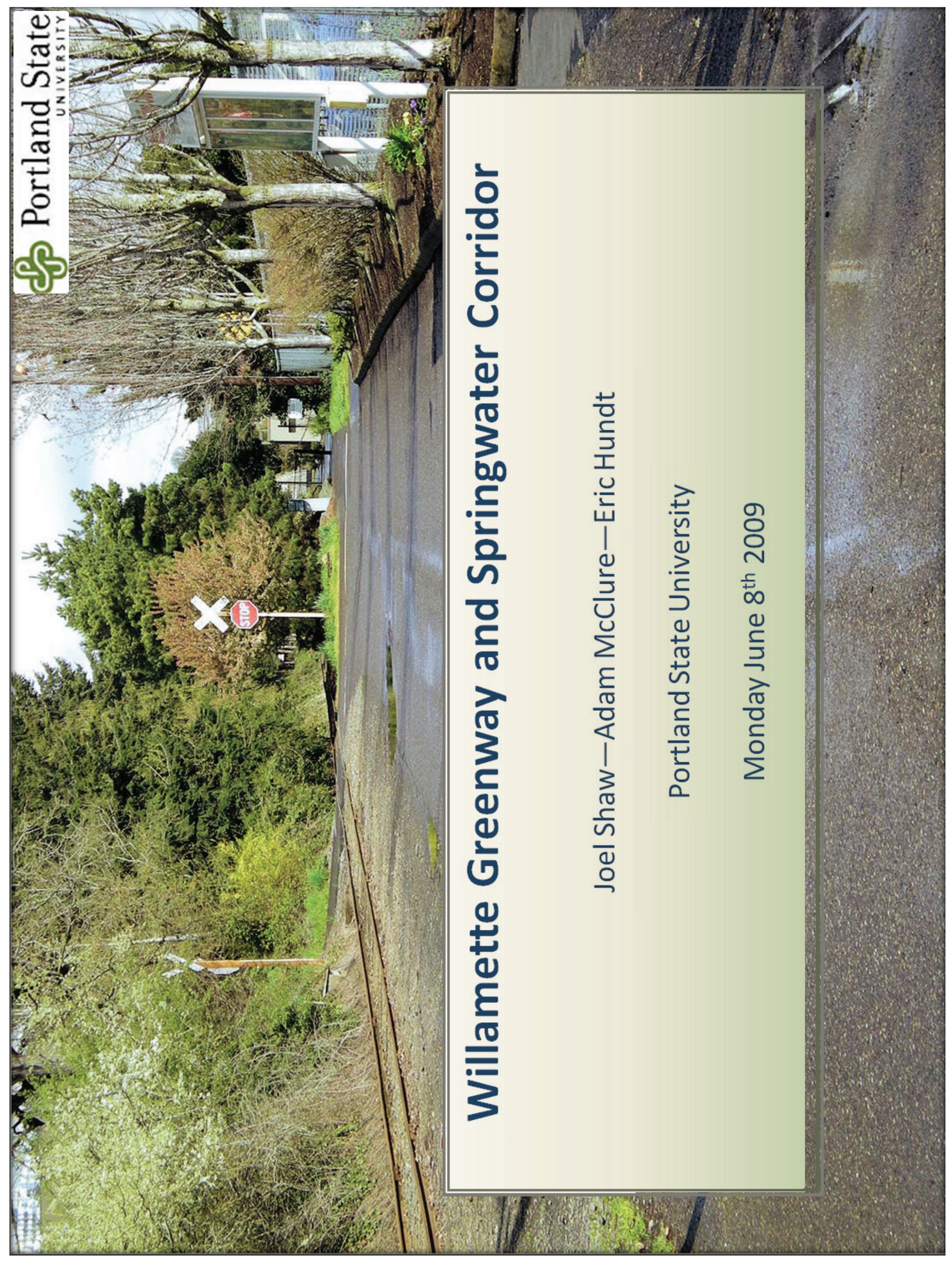




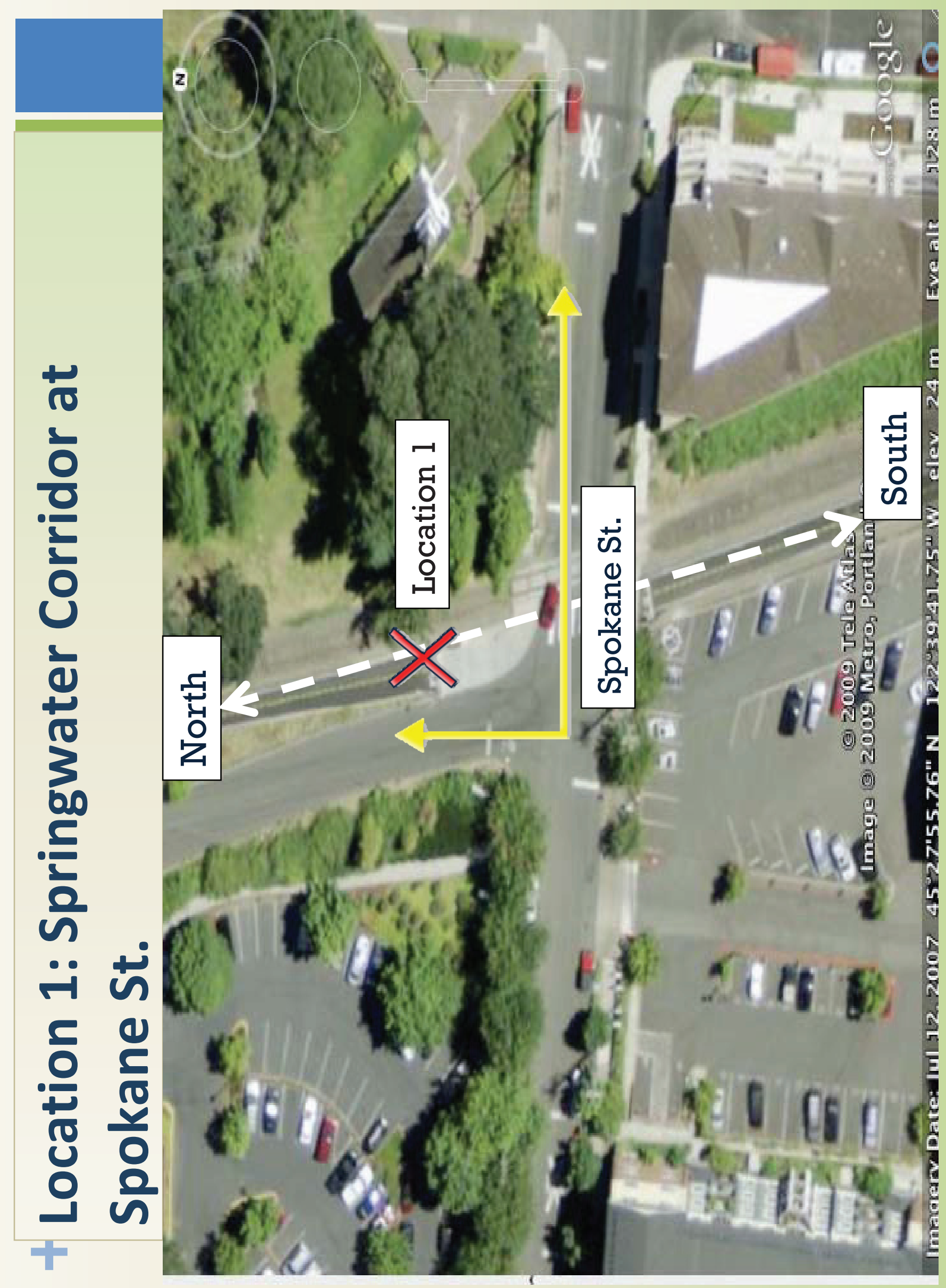




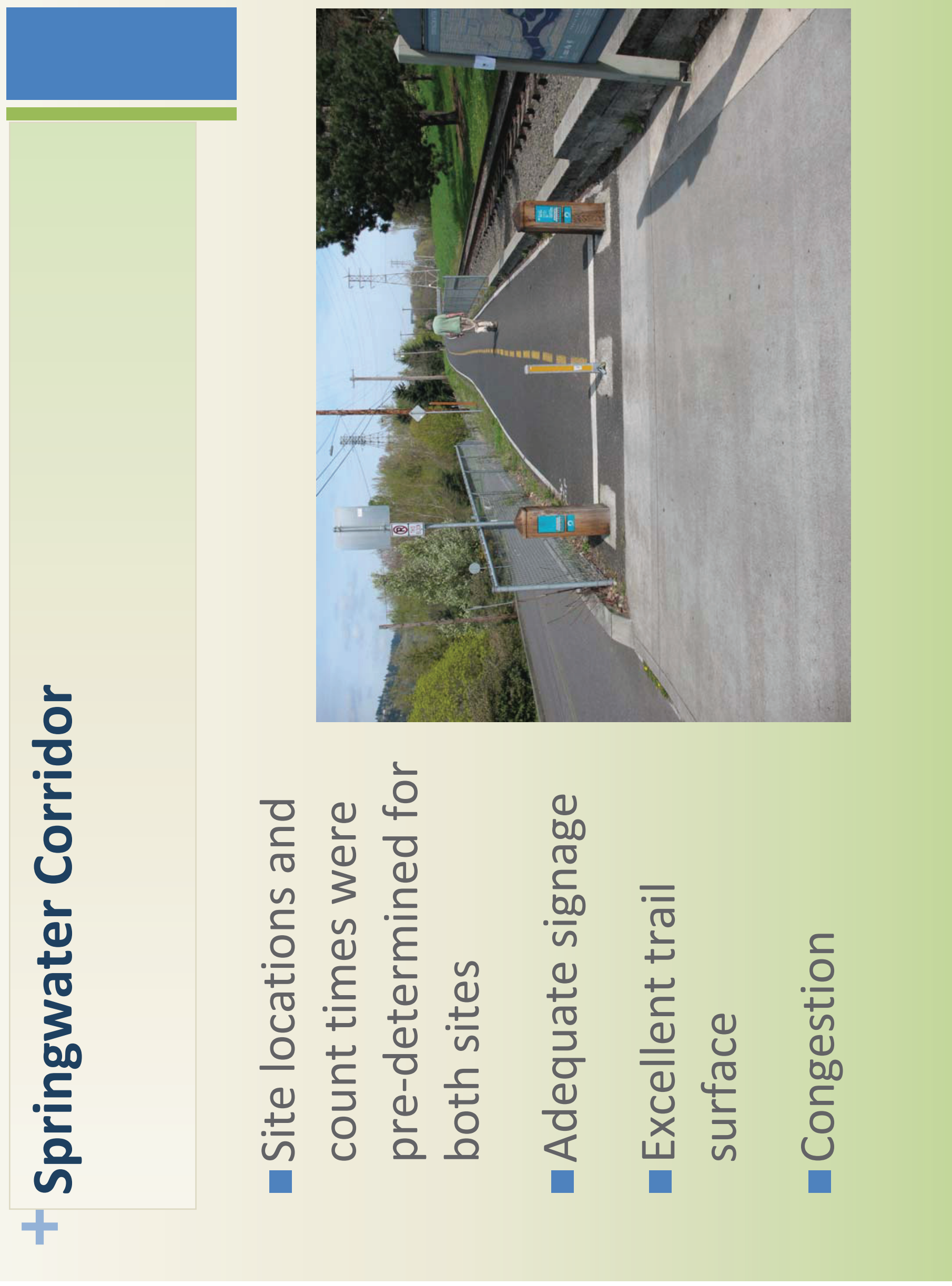




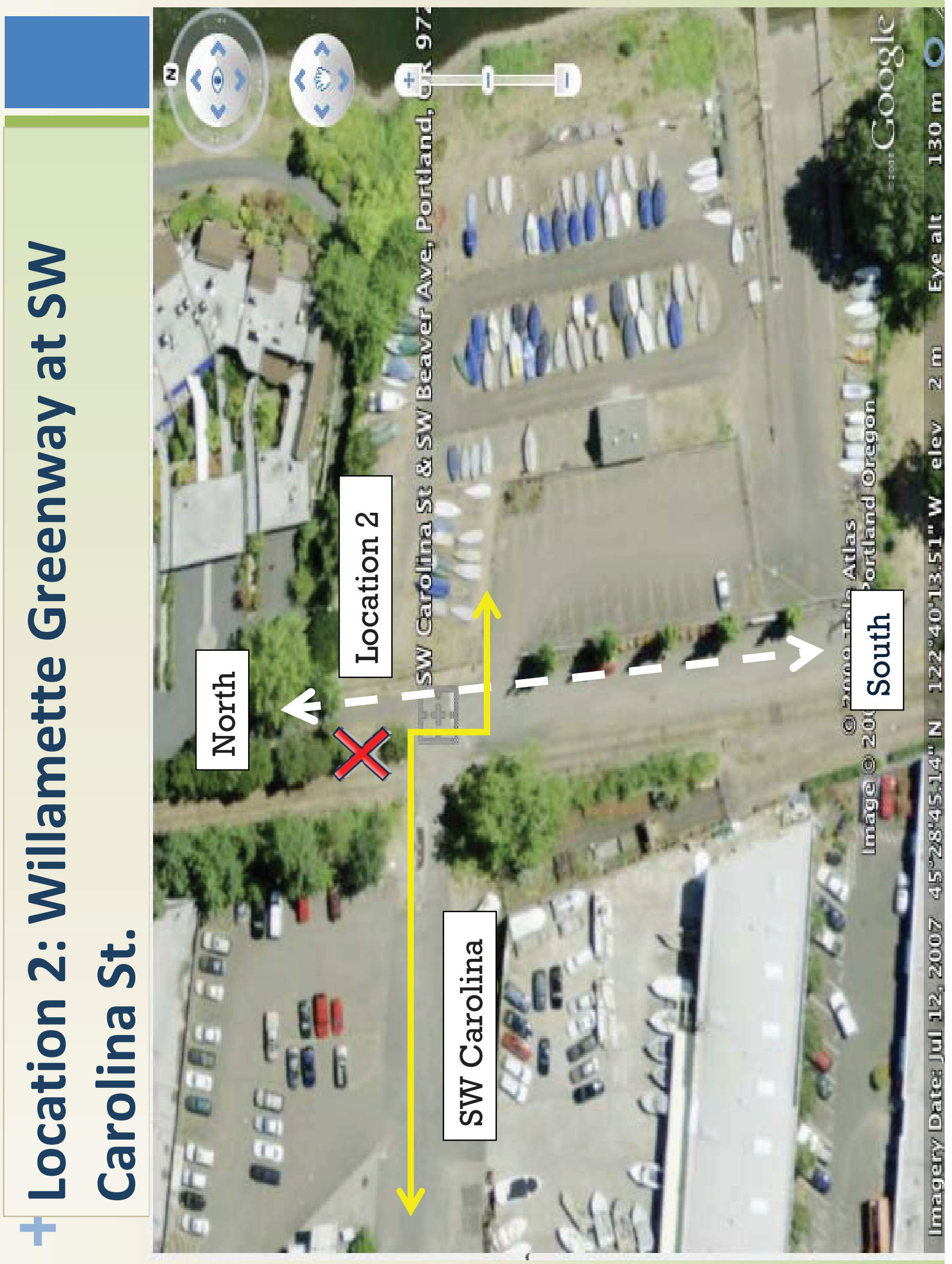




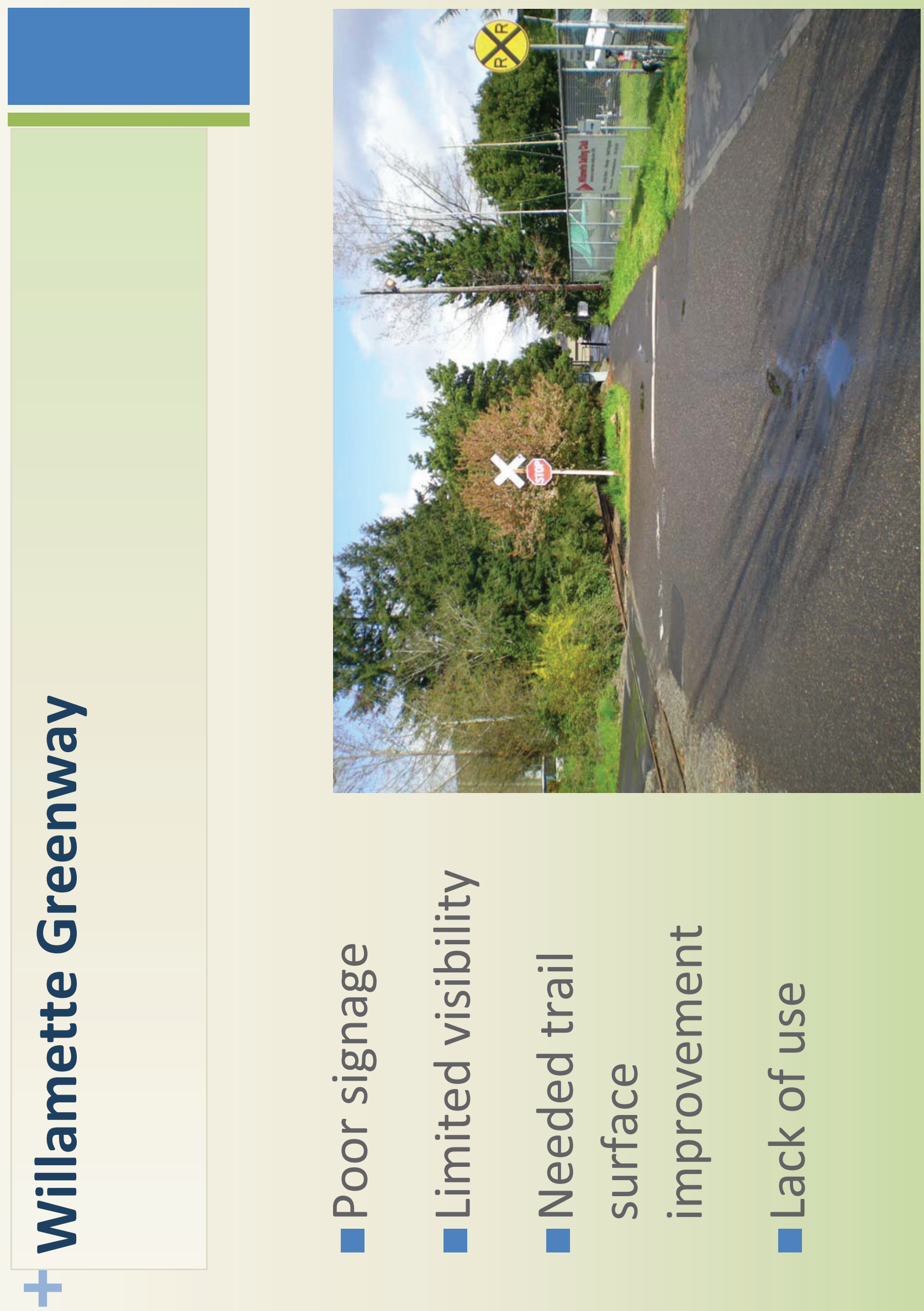



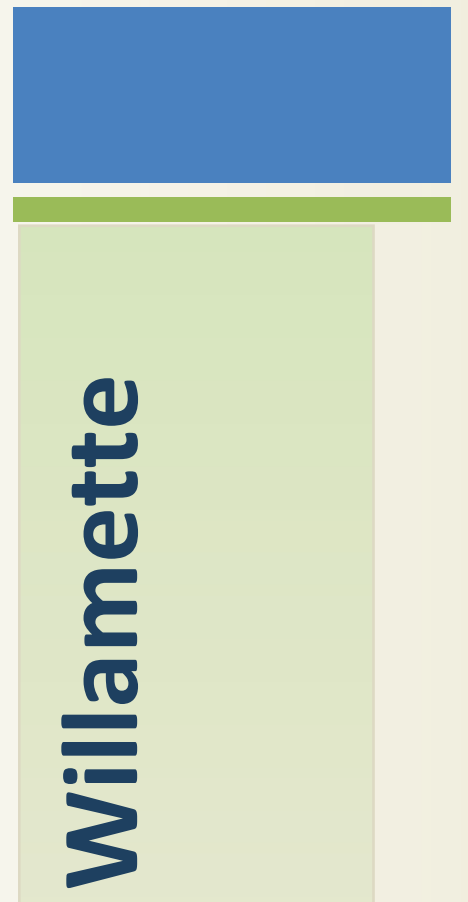

a

2

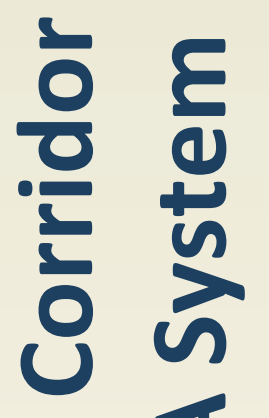

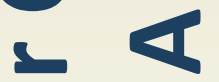

(1) $:$

1010

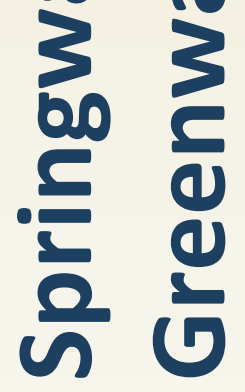

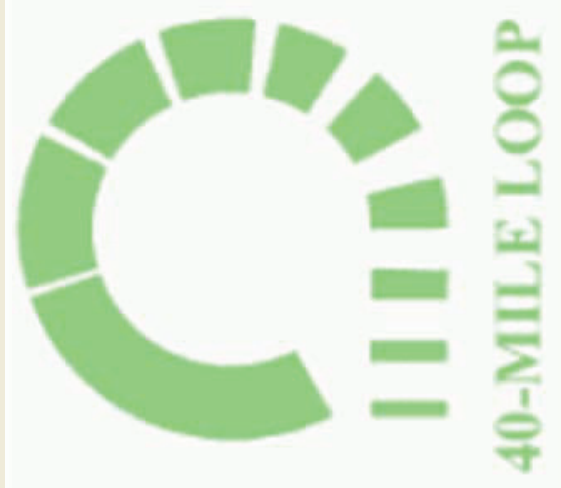

4

능 든

으

$\sim \frac{E}{ \pm}$

$\pi \stackrel{0}{0} \geqslant$

0 त 0

\pm 든 $ᄐ$

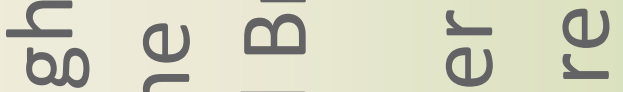

$\frac{3}{0}$ ए

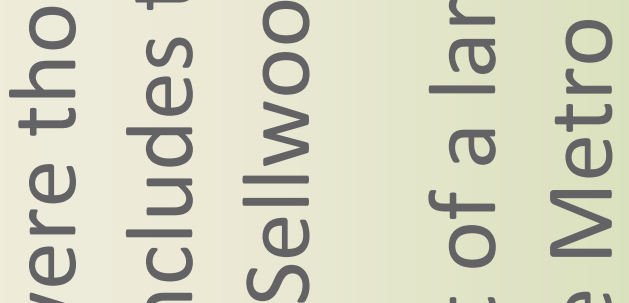

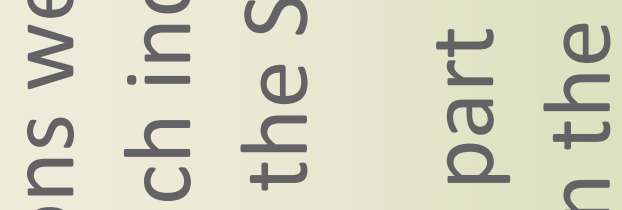

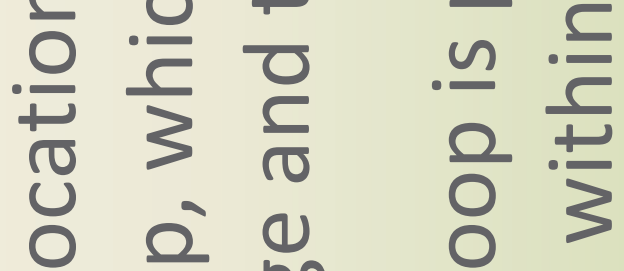

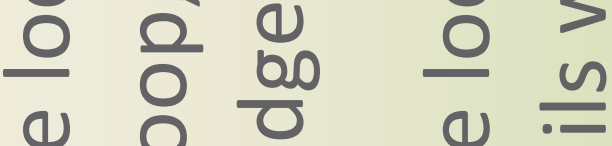

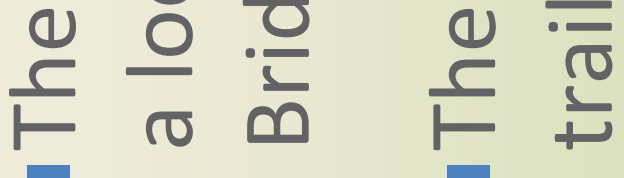




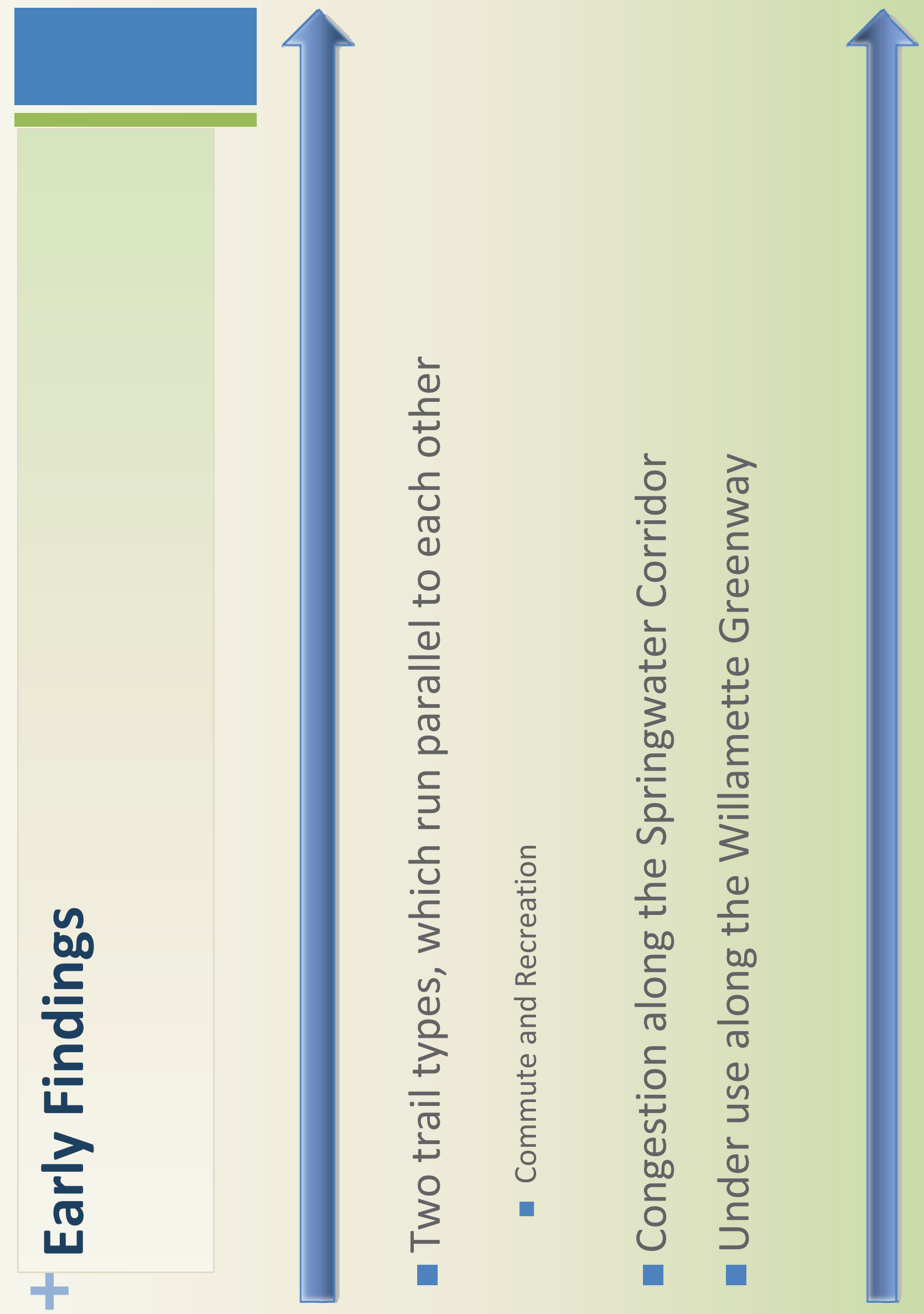



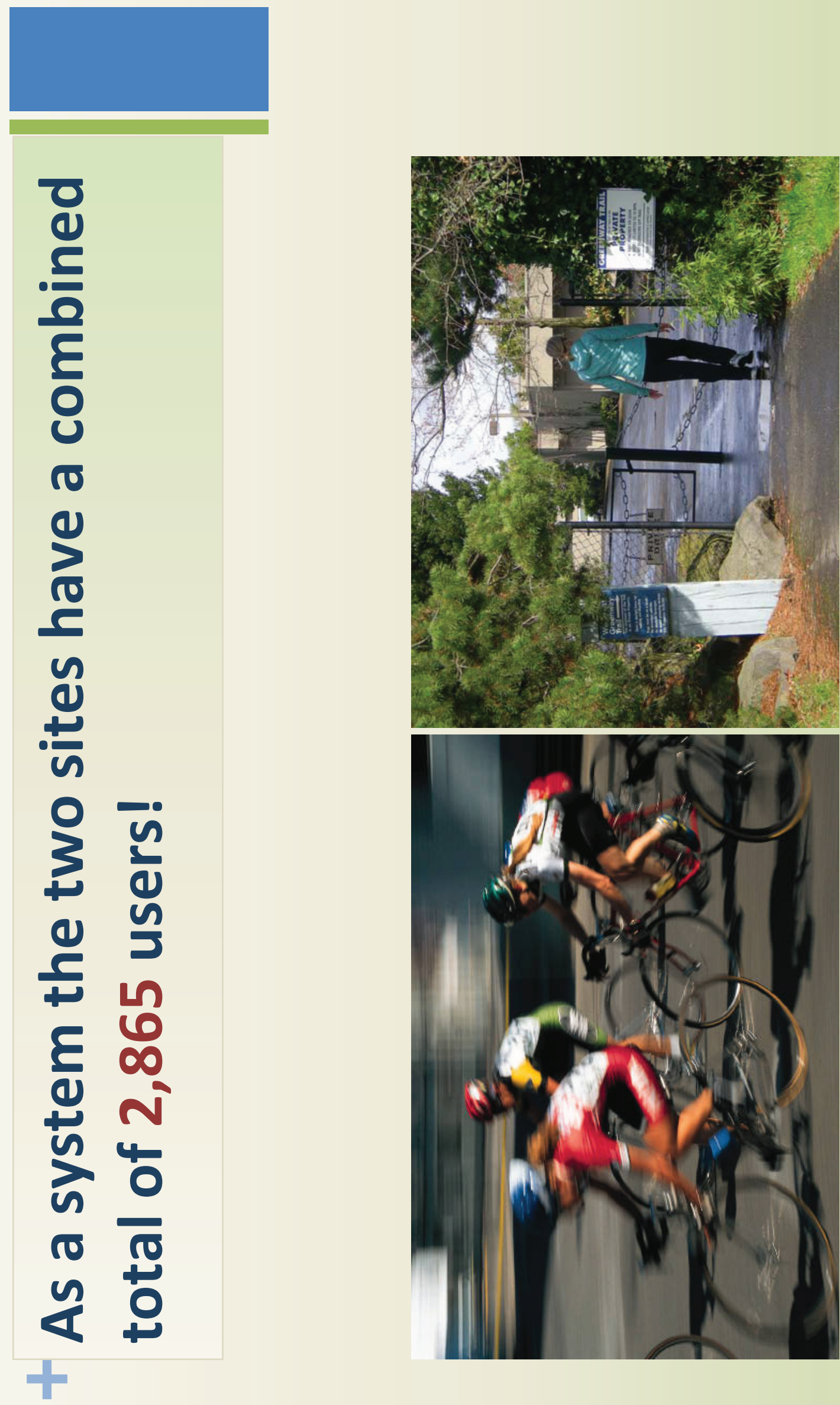


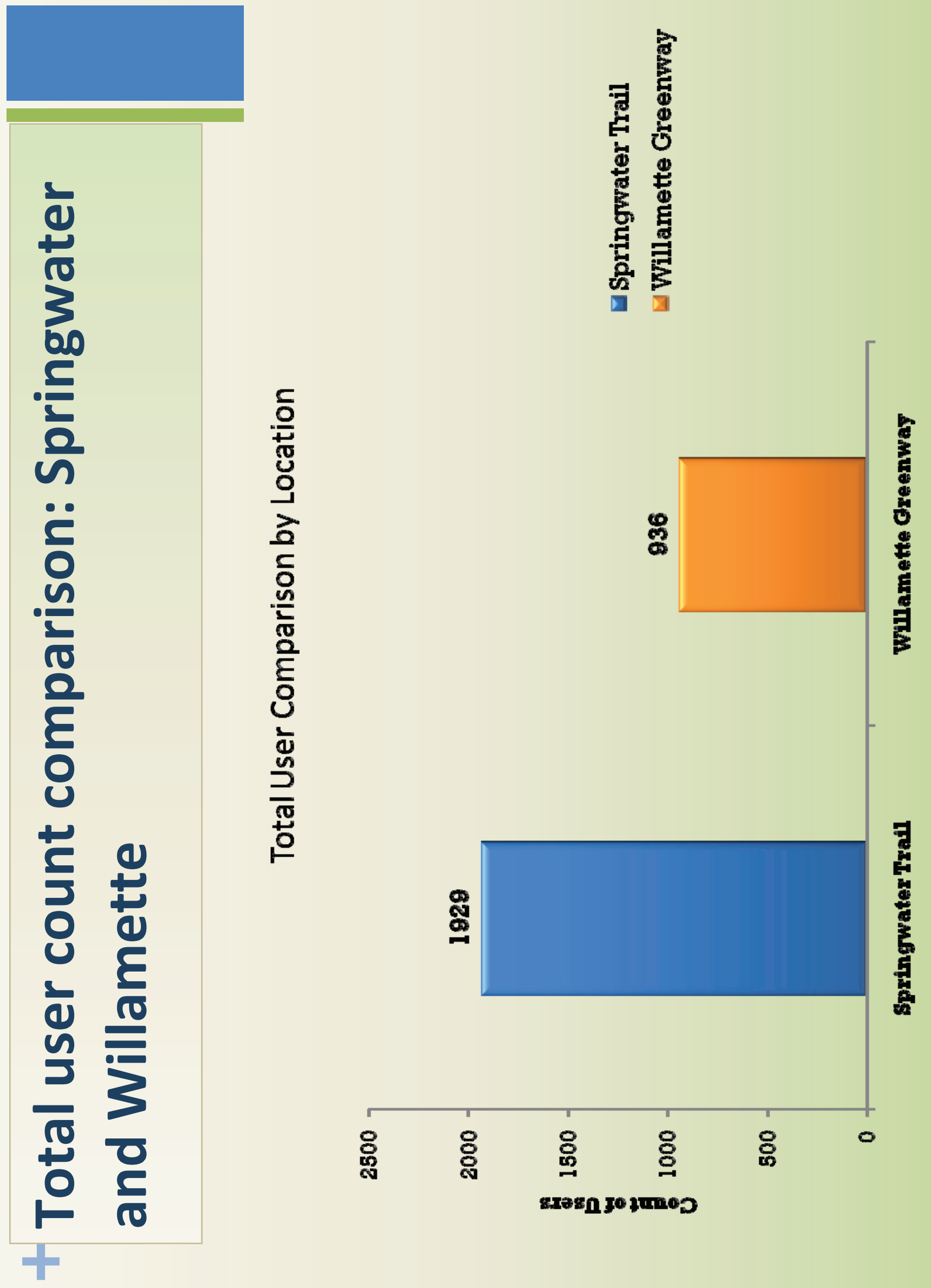



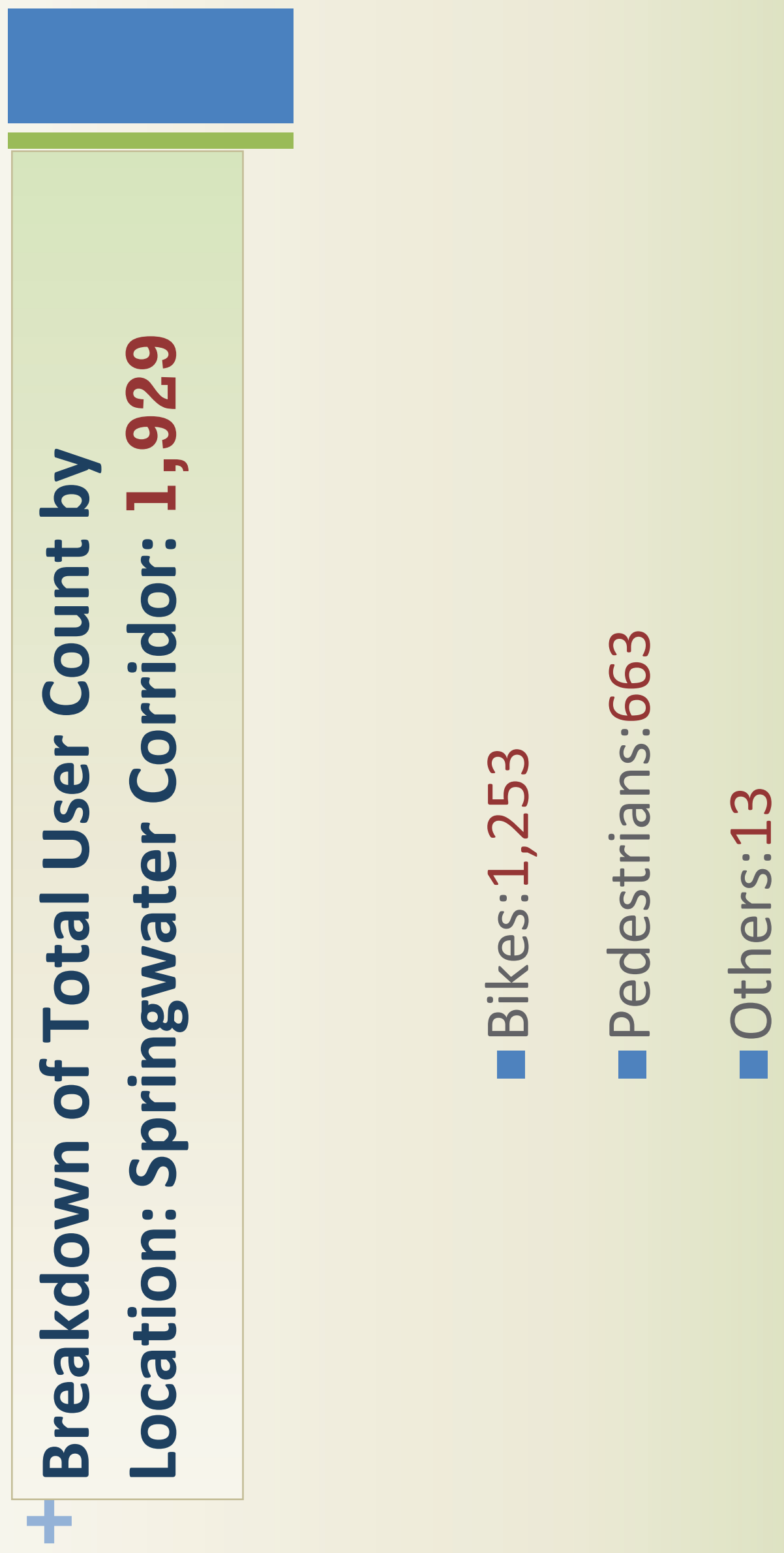

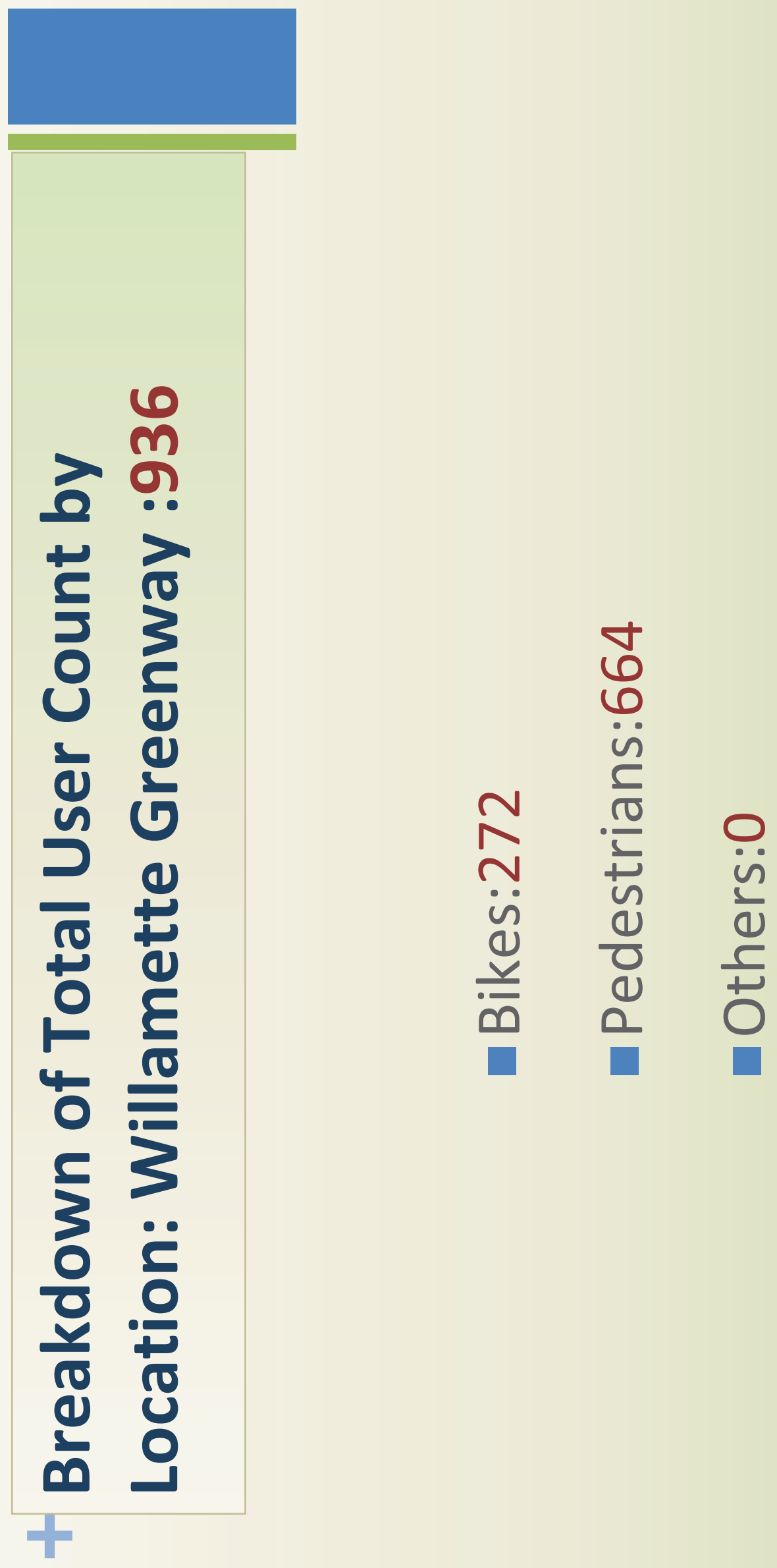


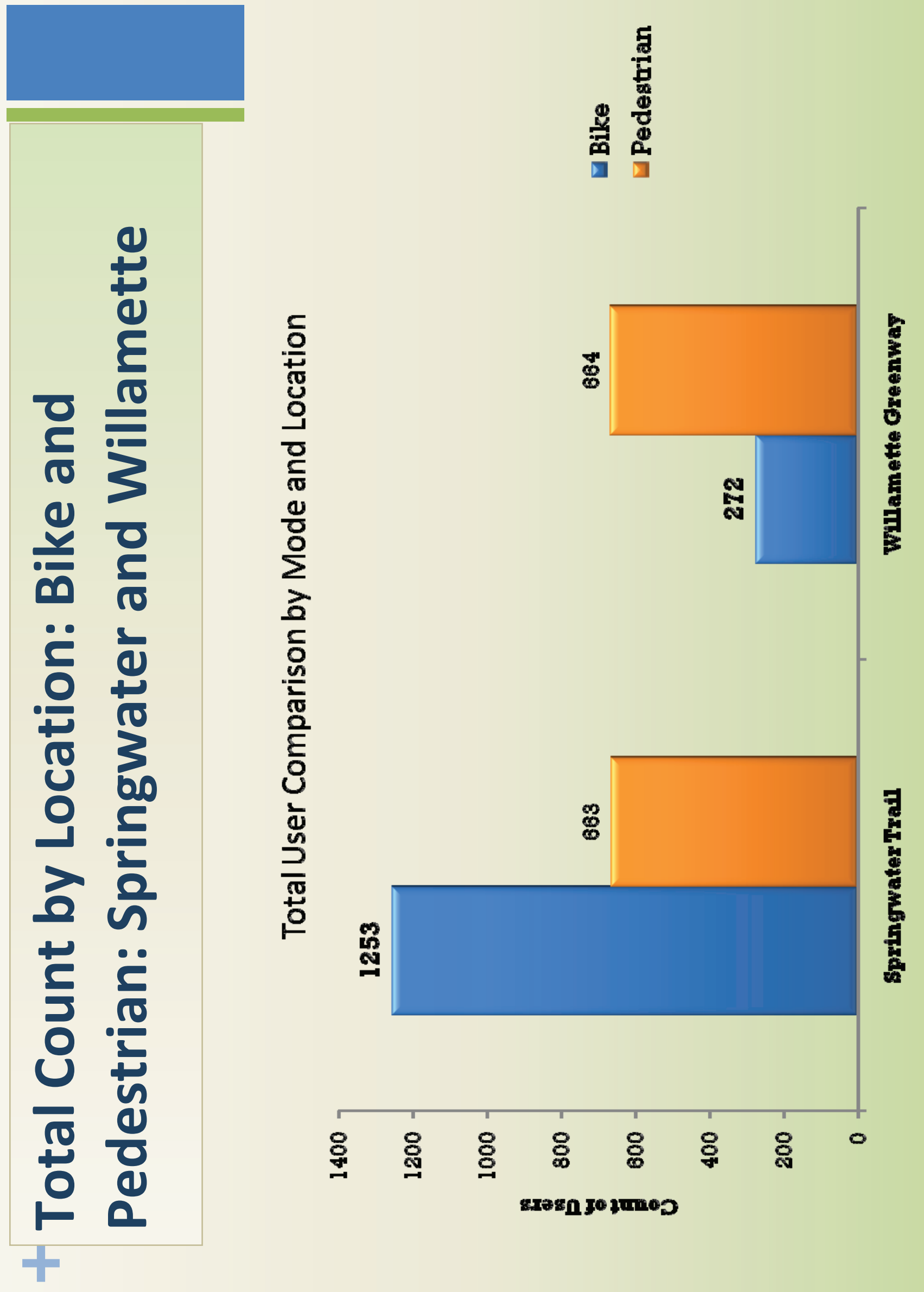




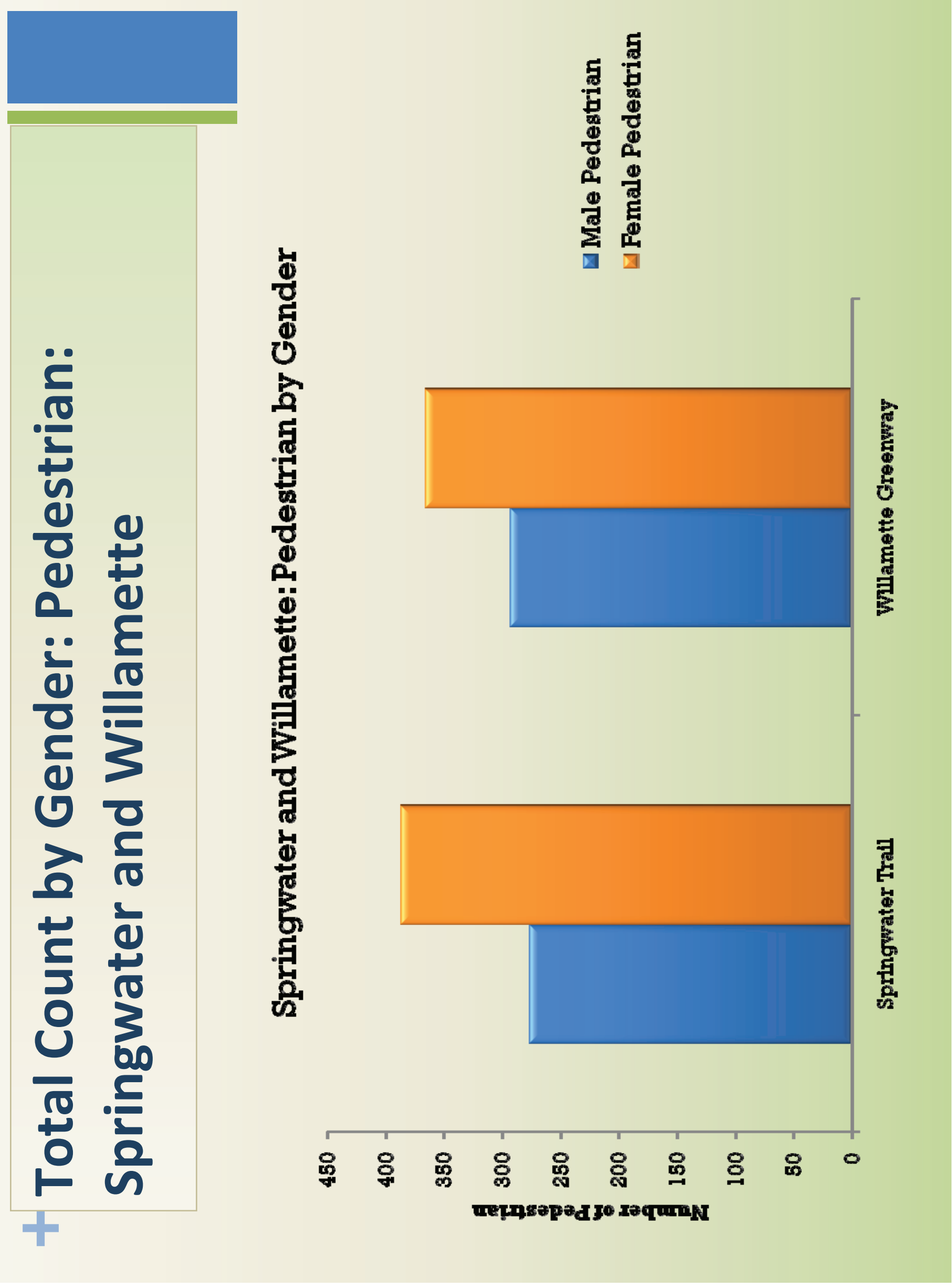



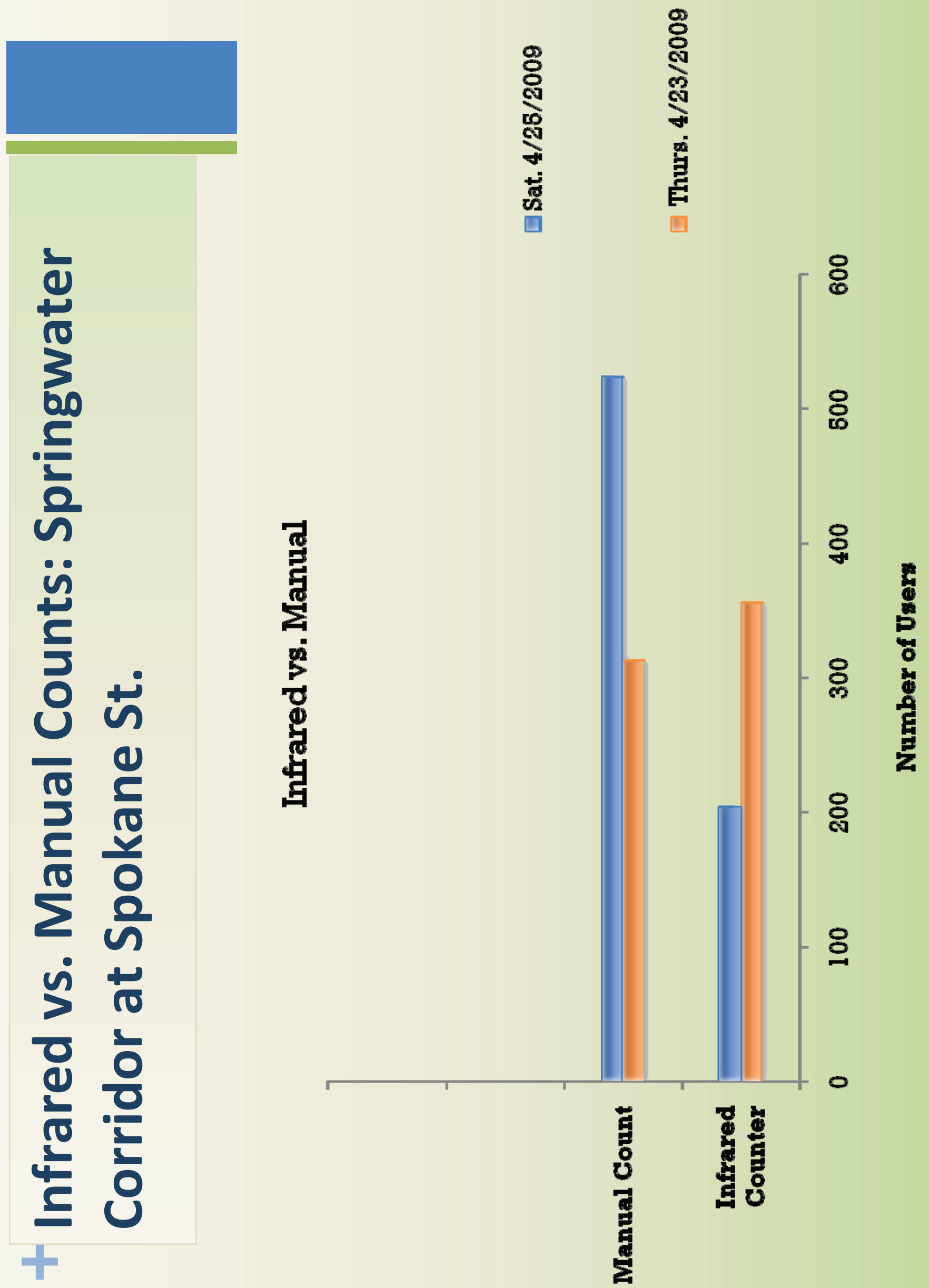


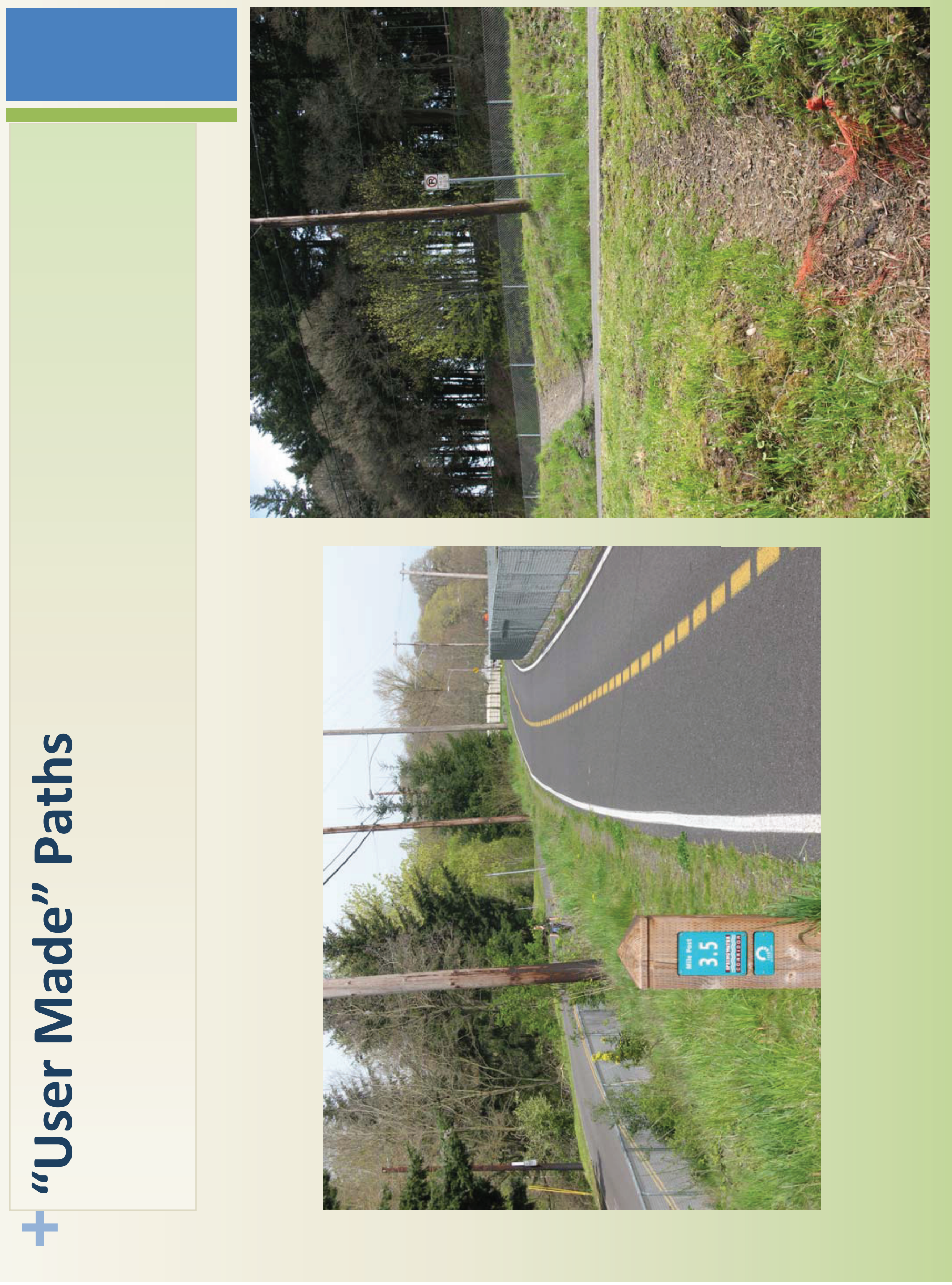




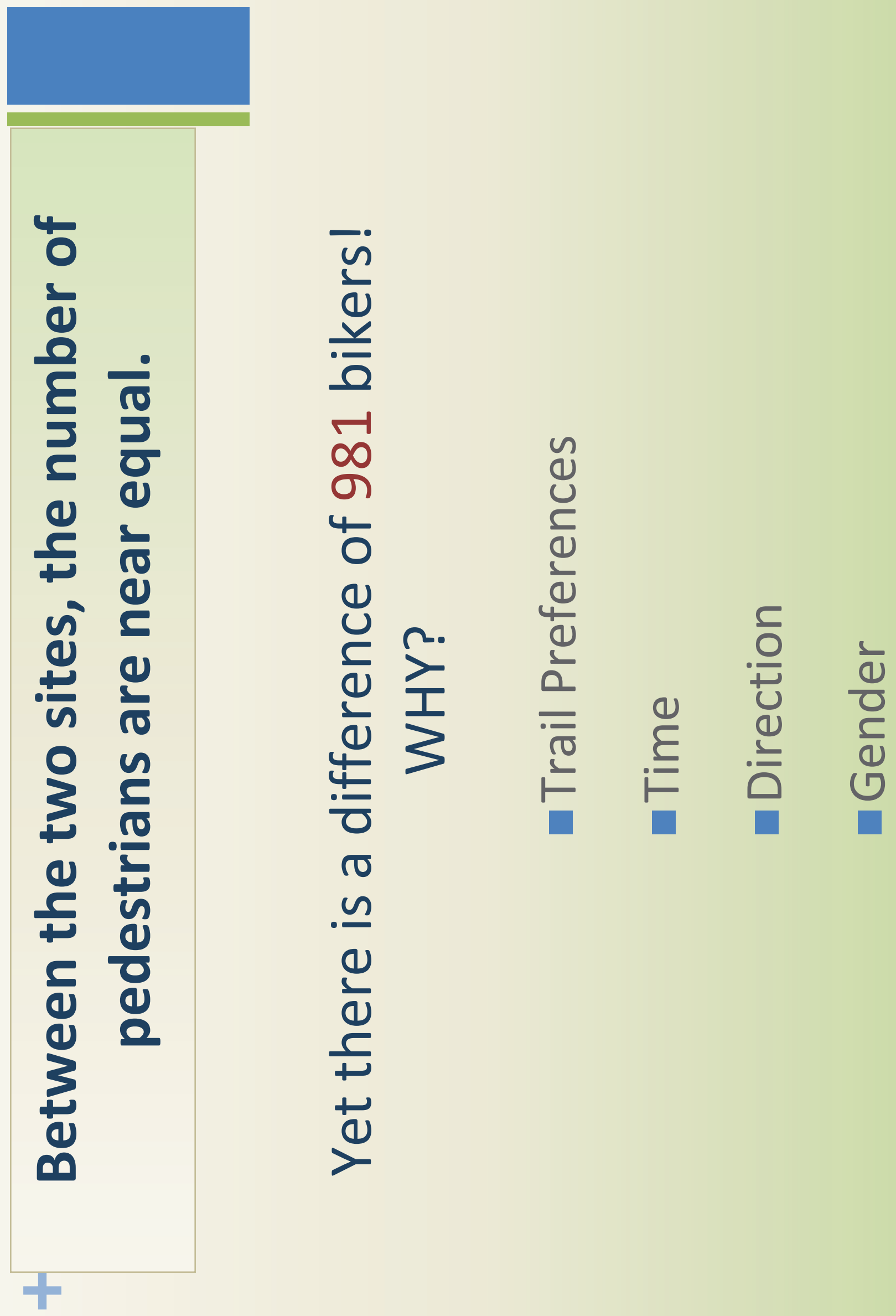



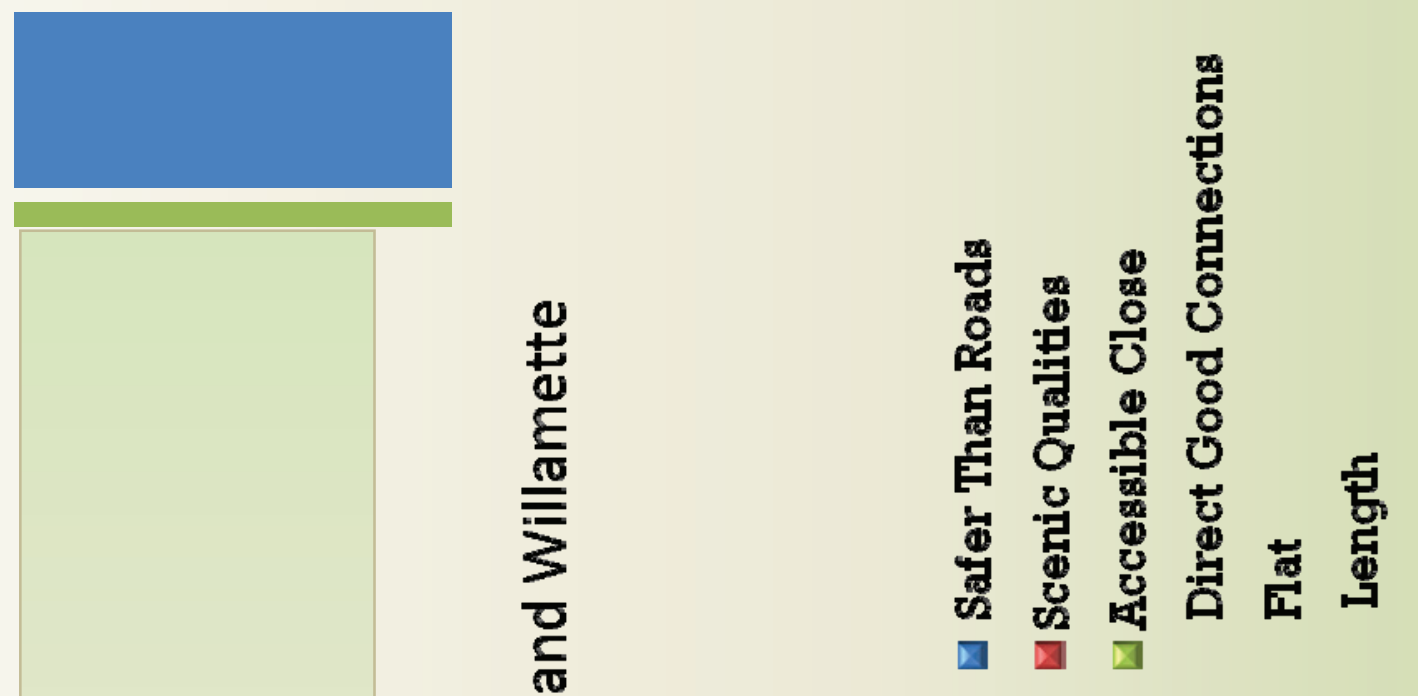

1)

4

3

00

든

产

2
2
2

(

(1) 2

4

1

$\frac{1}{5}$

$\overline{\overline{0}}$

(U)

$\frac{1}{t}$

(1)

(a)

(1)

(1) 2

물 을

$\frac{\infty}{5}$

ড্

동

$\stackrel{4}{\alpha}$

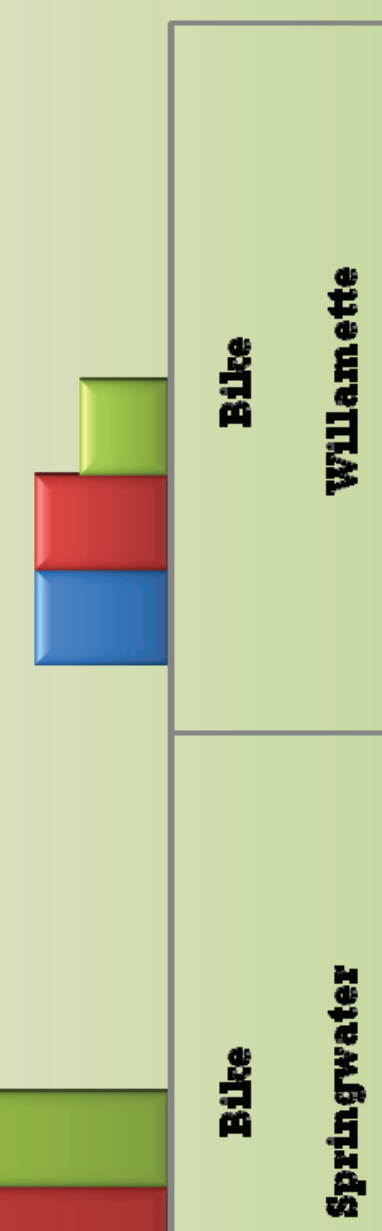

- 

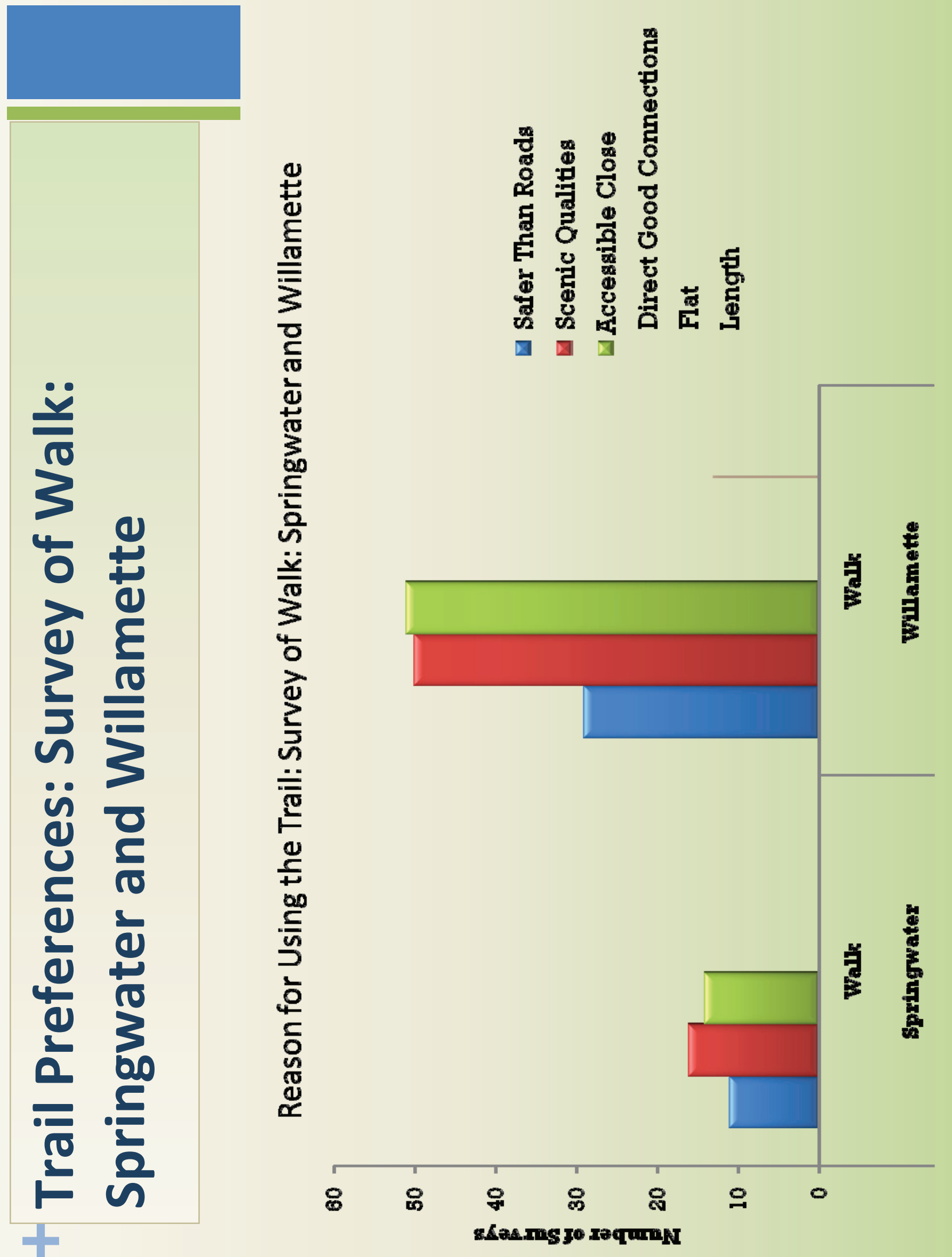


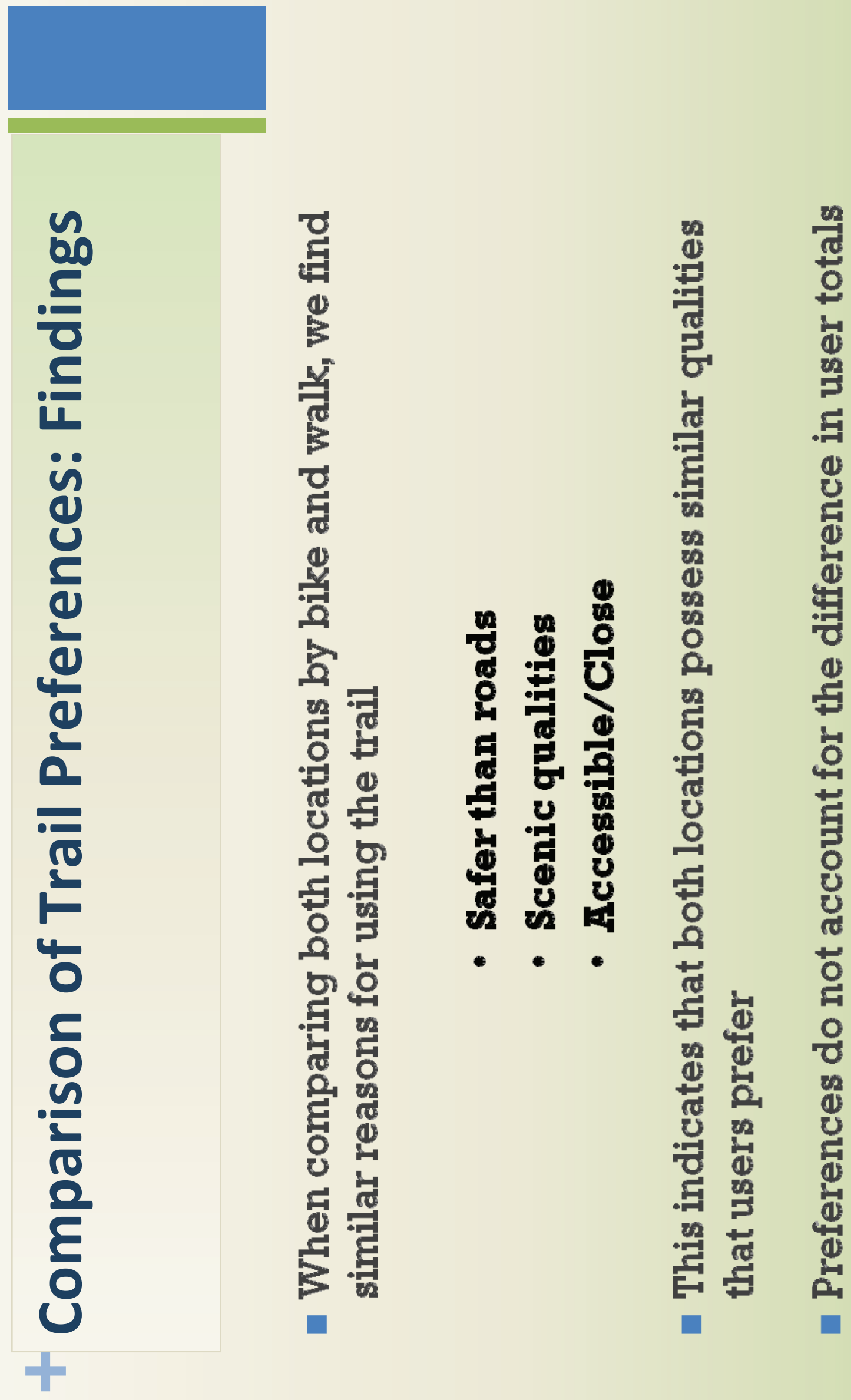



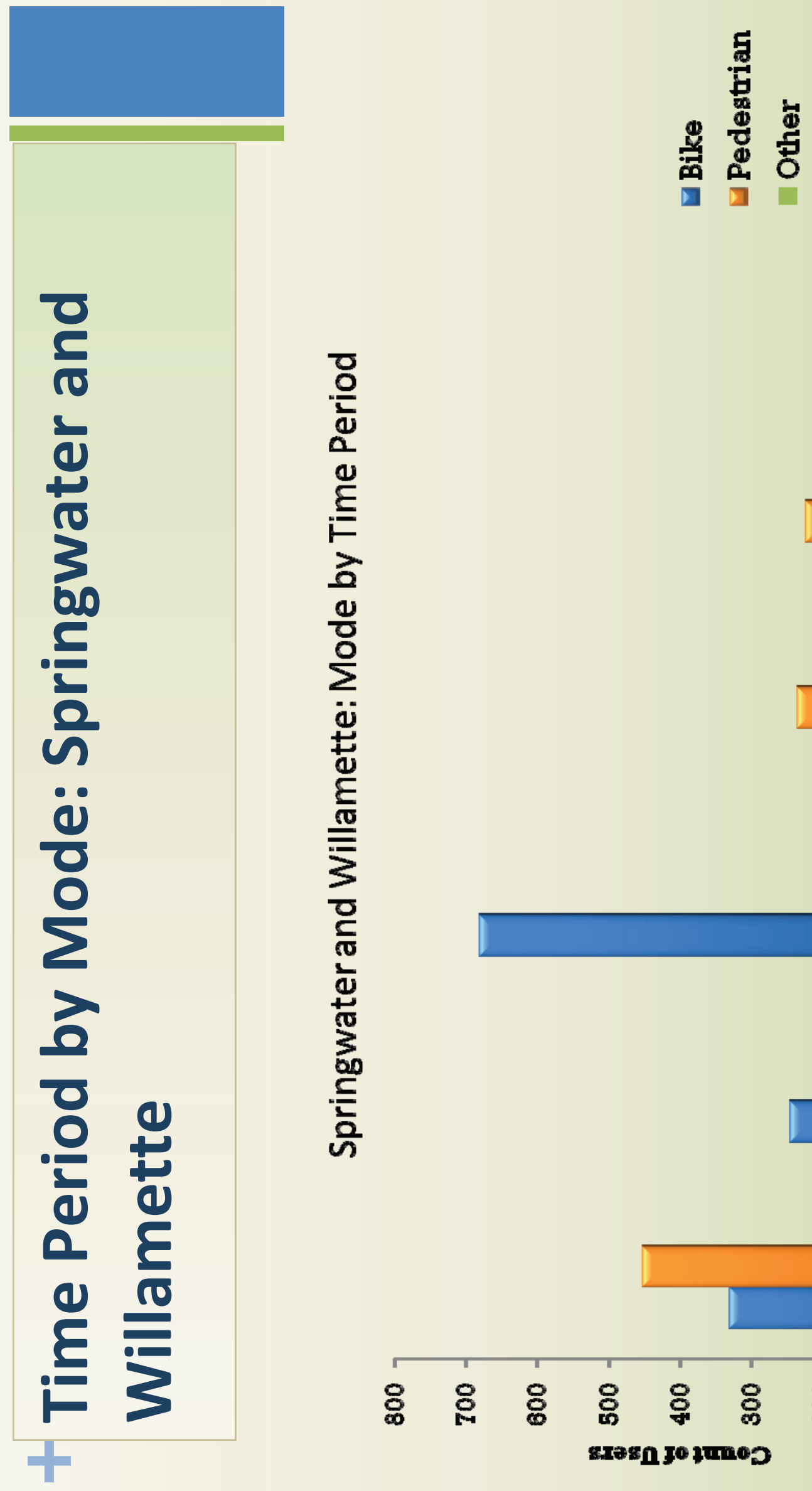

은

$\stackrel{\mathscr{E}}{\underline{E}}$

ลิ

1

$\sum^{\circ}$

ذئ

U

$\frac{E}{\sigma}$

$\stackrel{\frac{\pi}{\bar{N}}}{3}$

뭉

닌

(0)

$\sum_{00}$

은

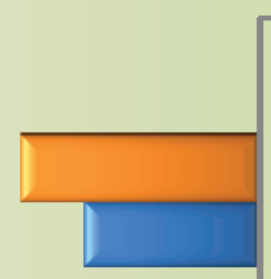

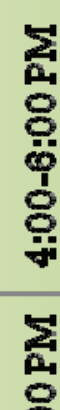

요
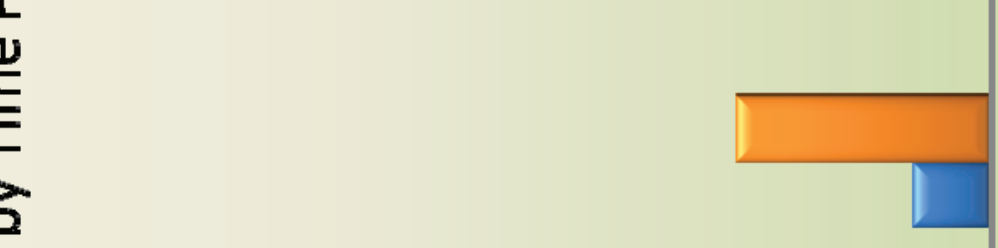

유

?

案

5

งิ

E

옹

弯 


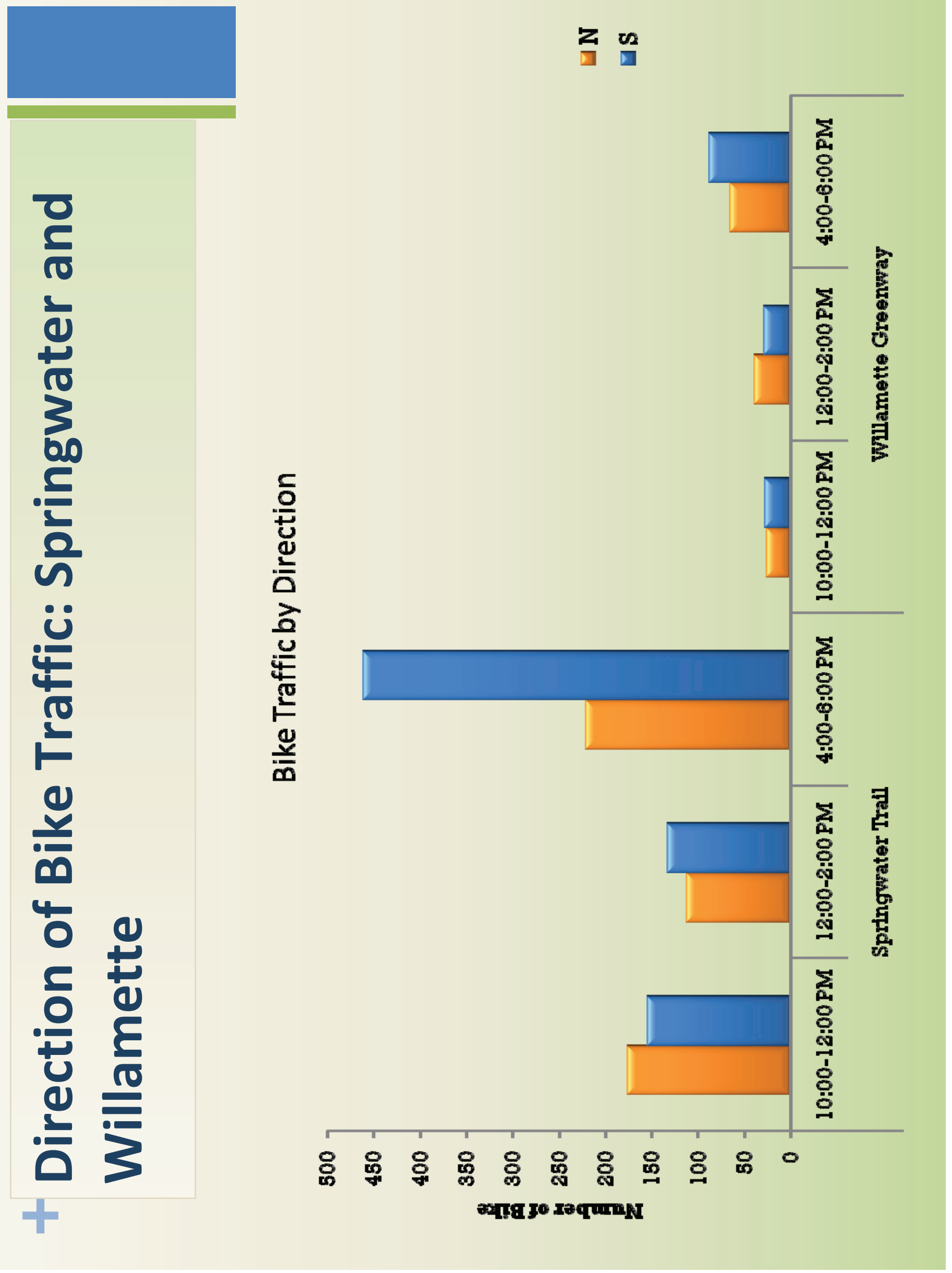




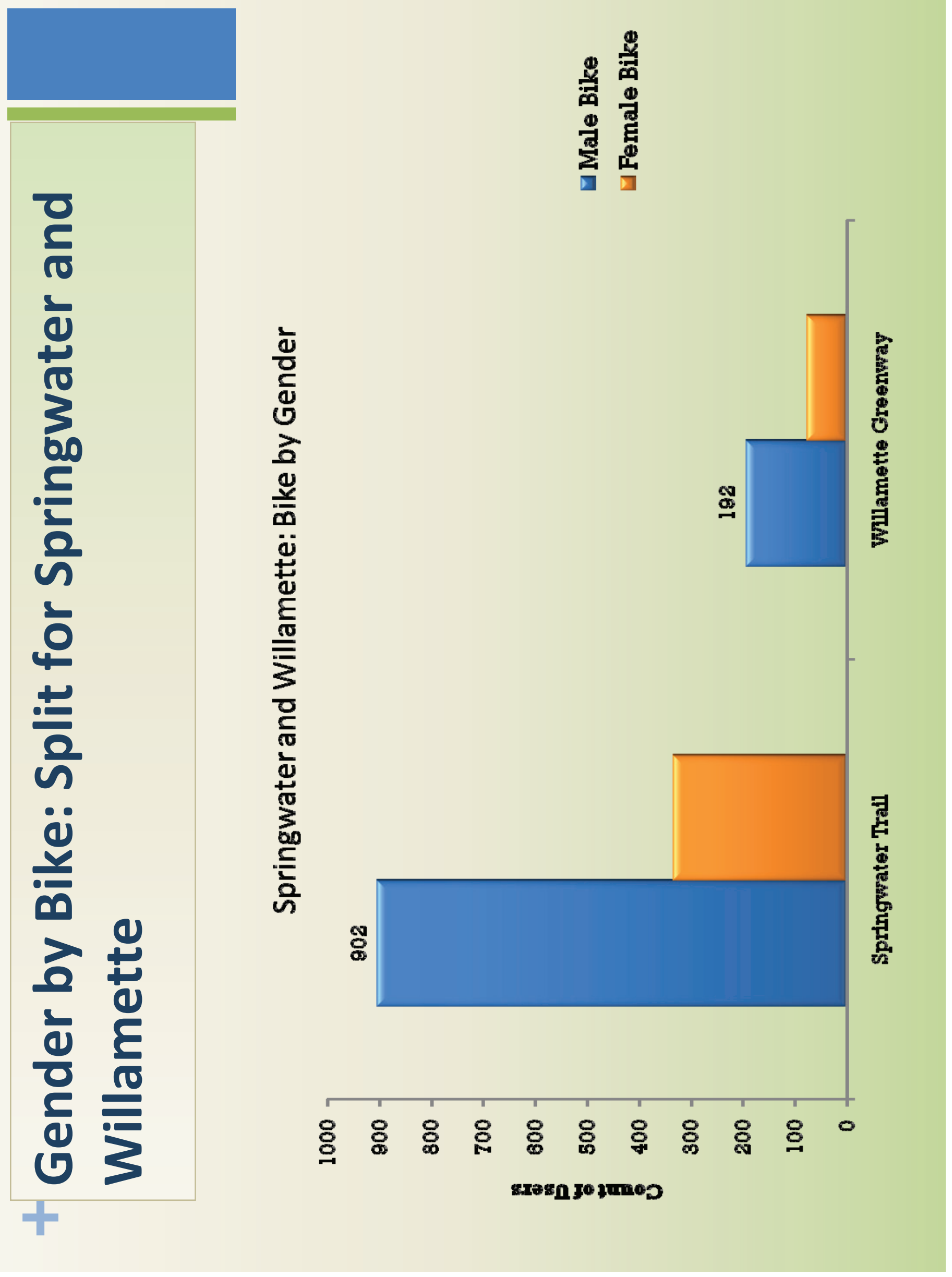




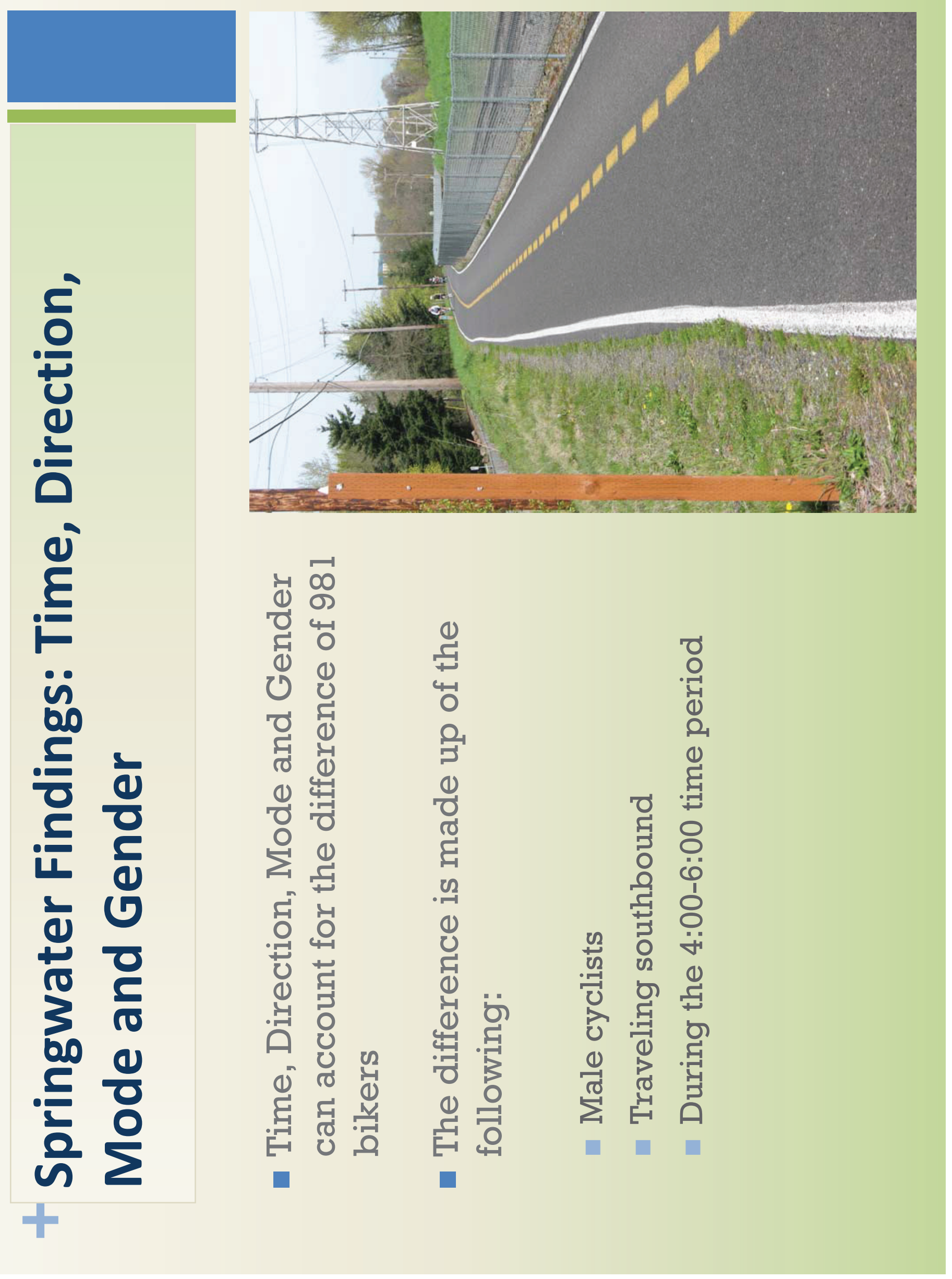




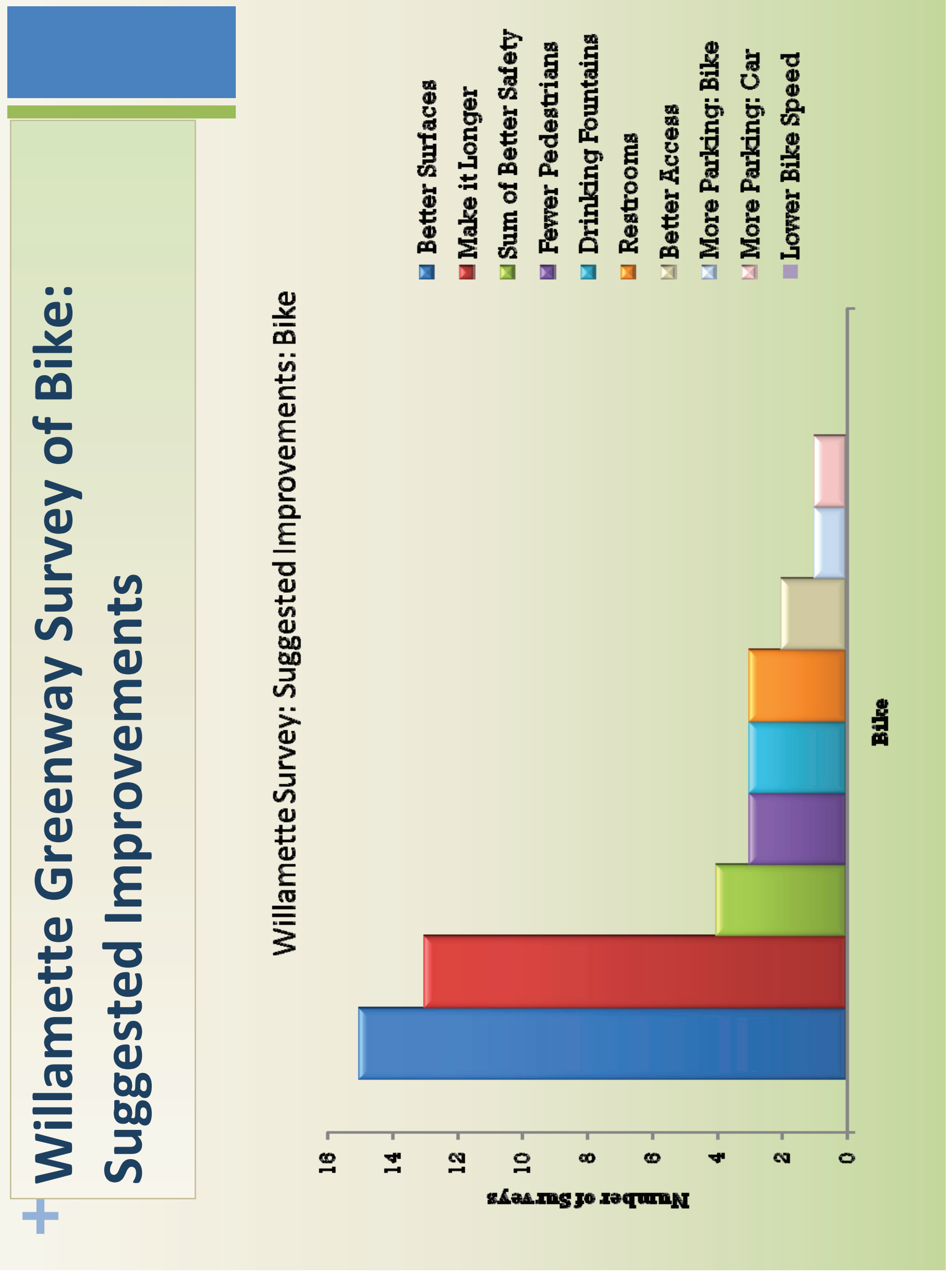



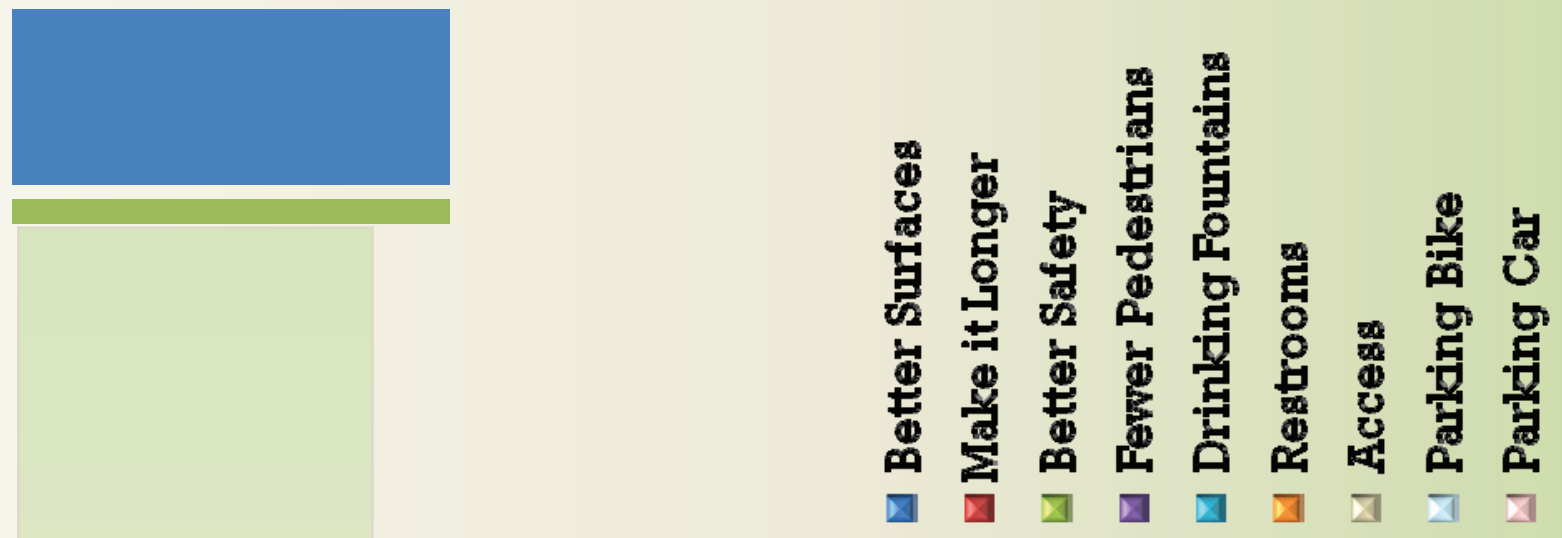

a)

$\frac{1}{6}$

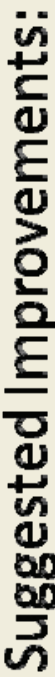

造

㐫

$\begin{array}{ll}0 & 0 \\ 2 & 4 \\ 6 & 0 \\ 5 & 0 \\ 2 & 0 \\ 0 & 0\end{array}$

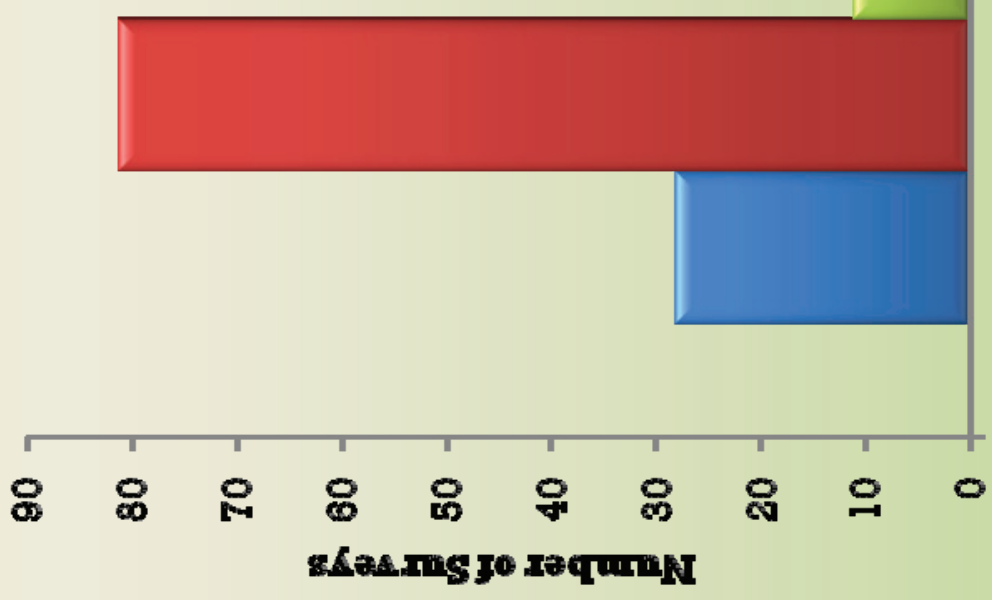

당 


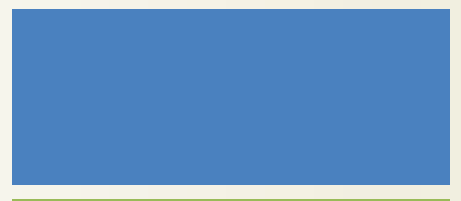

0
0
0
0
0
0
0
0
0

당 당

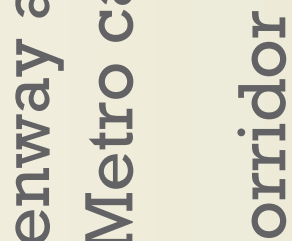

(1)

(당

¿

(1) क ह 1

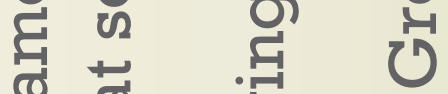

层

(1) 0 告 है

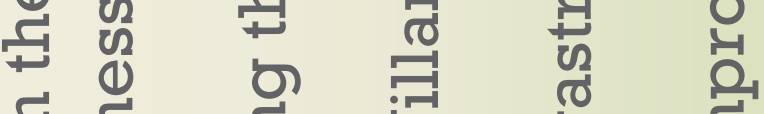

여

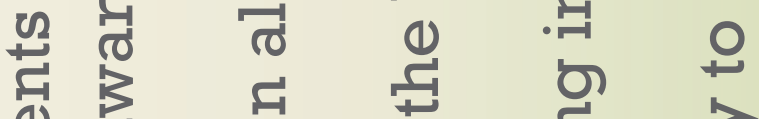

$\frac{\pi}{10}$

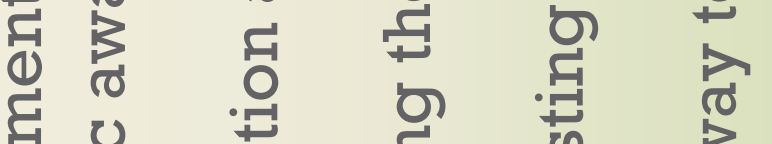

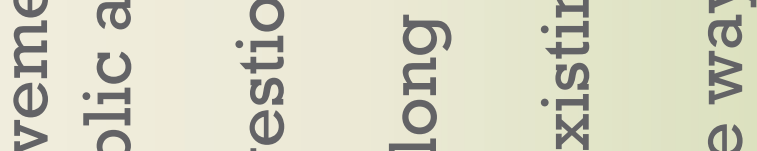

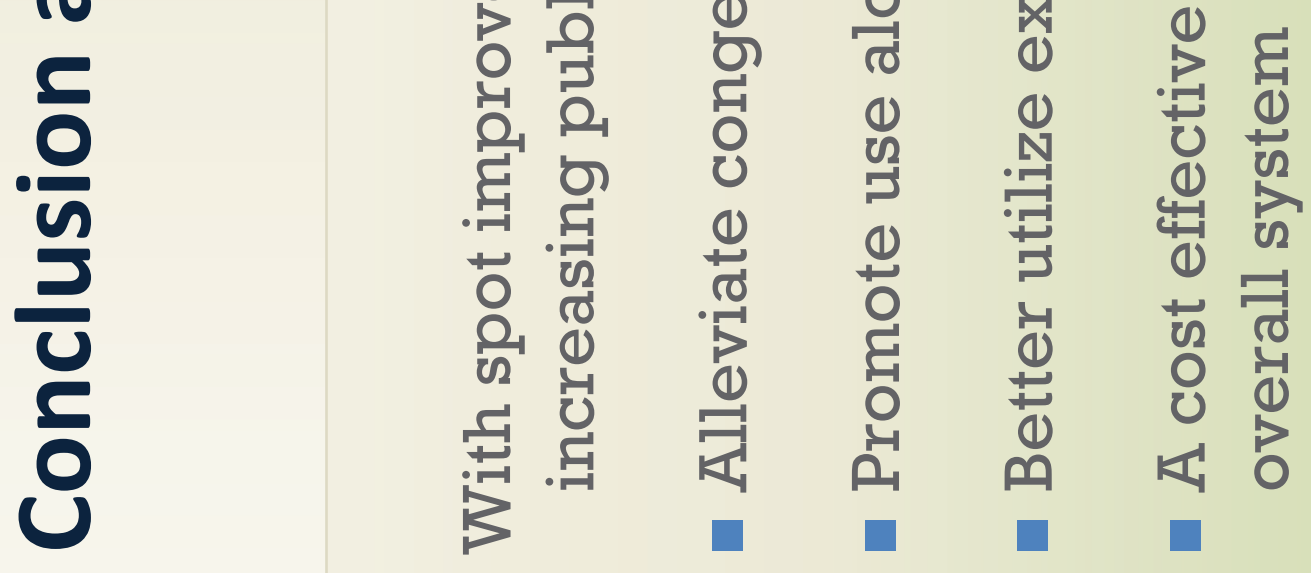



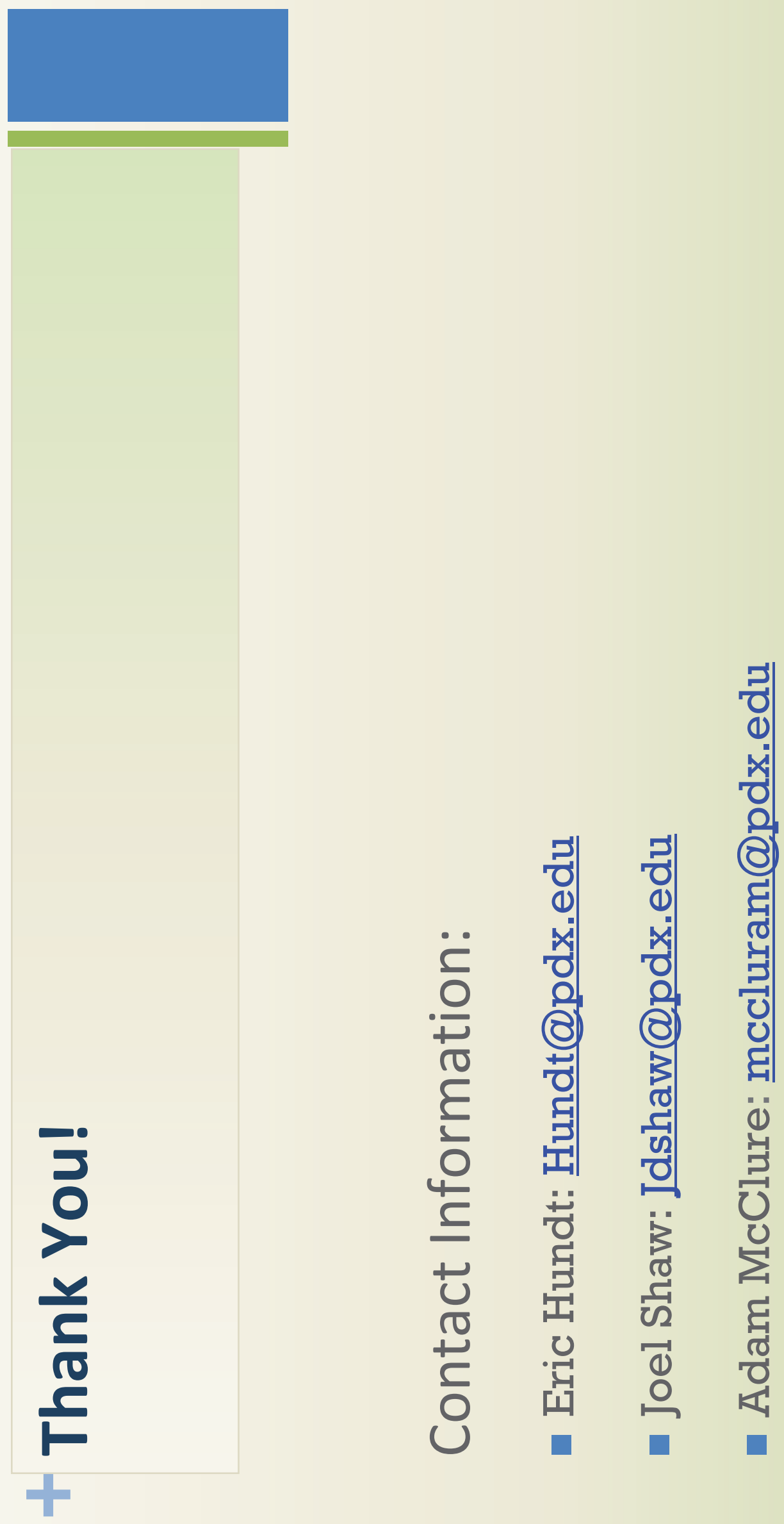


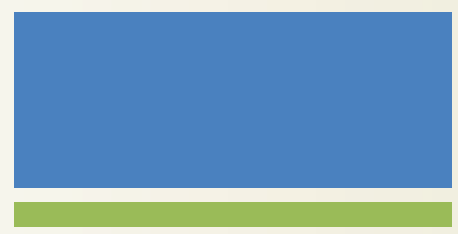

ช)

न

द्व

(1)

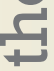

(1)

o

\%

द्व.

ํํㅇ

$\checkmark$

킹

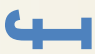

0

$\boldsymbol{\Omega}$

$\cdot 7$

ช2

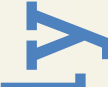

तु

嵌

명

है요 정

음

(1)

동

(1)

兘 

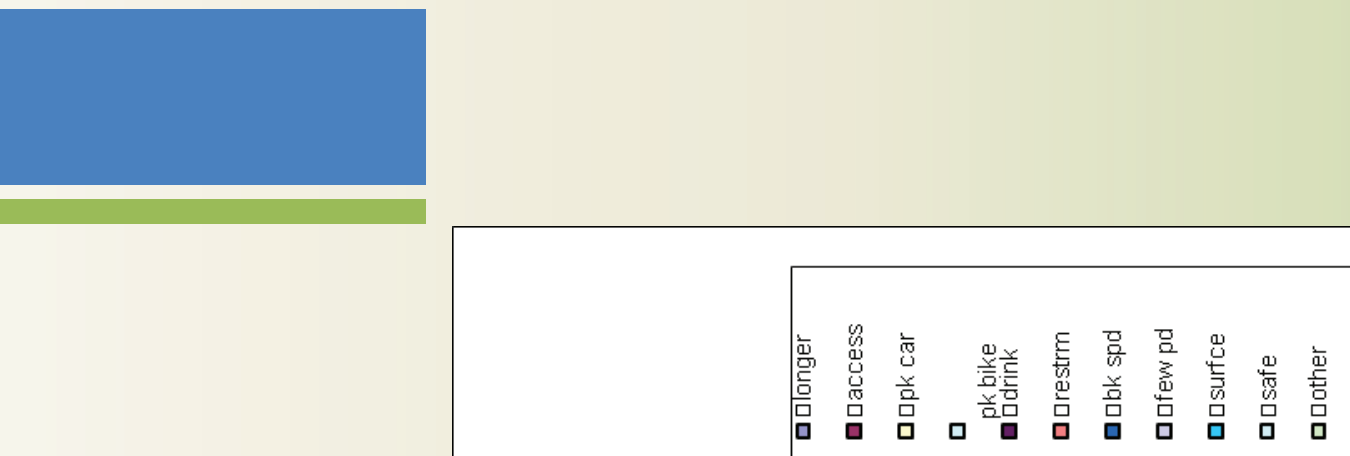

है

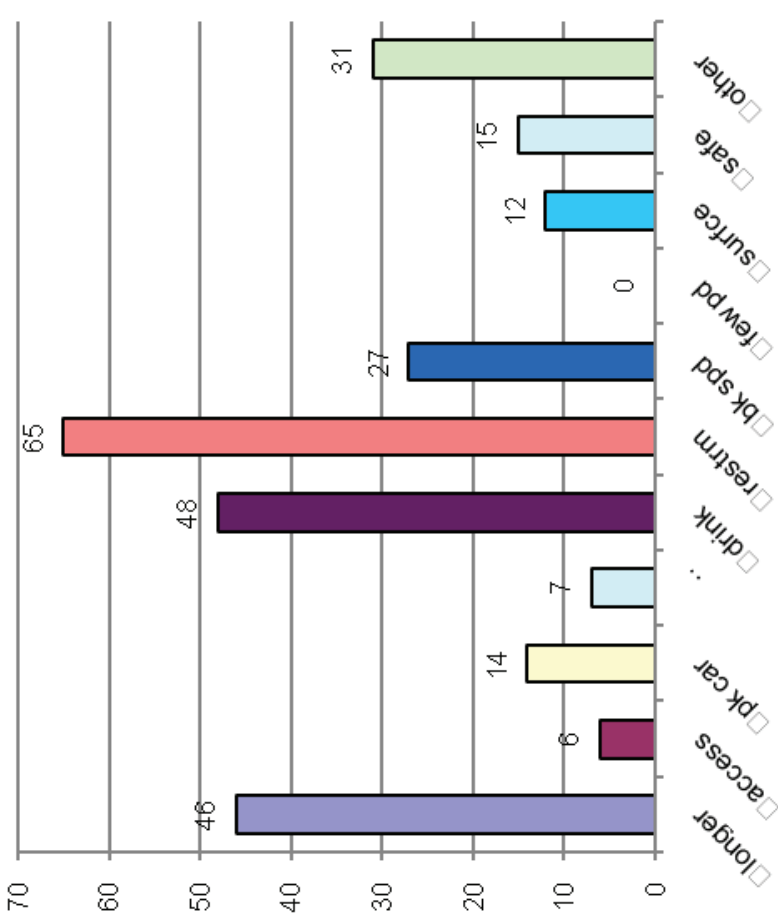




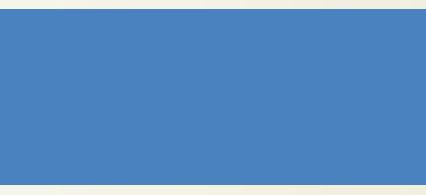

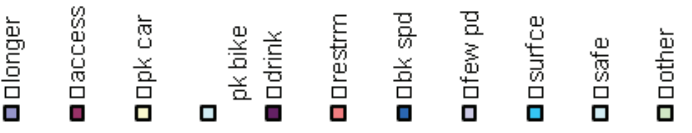

ڤั)
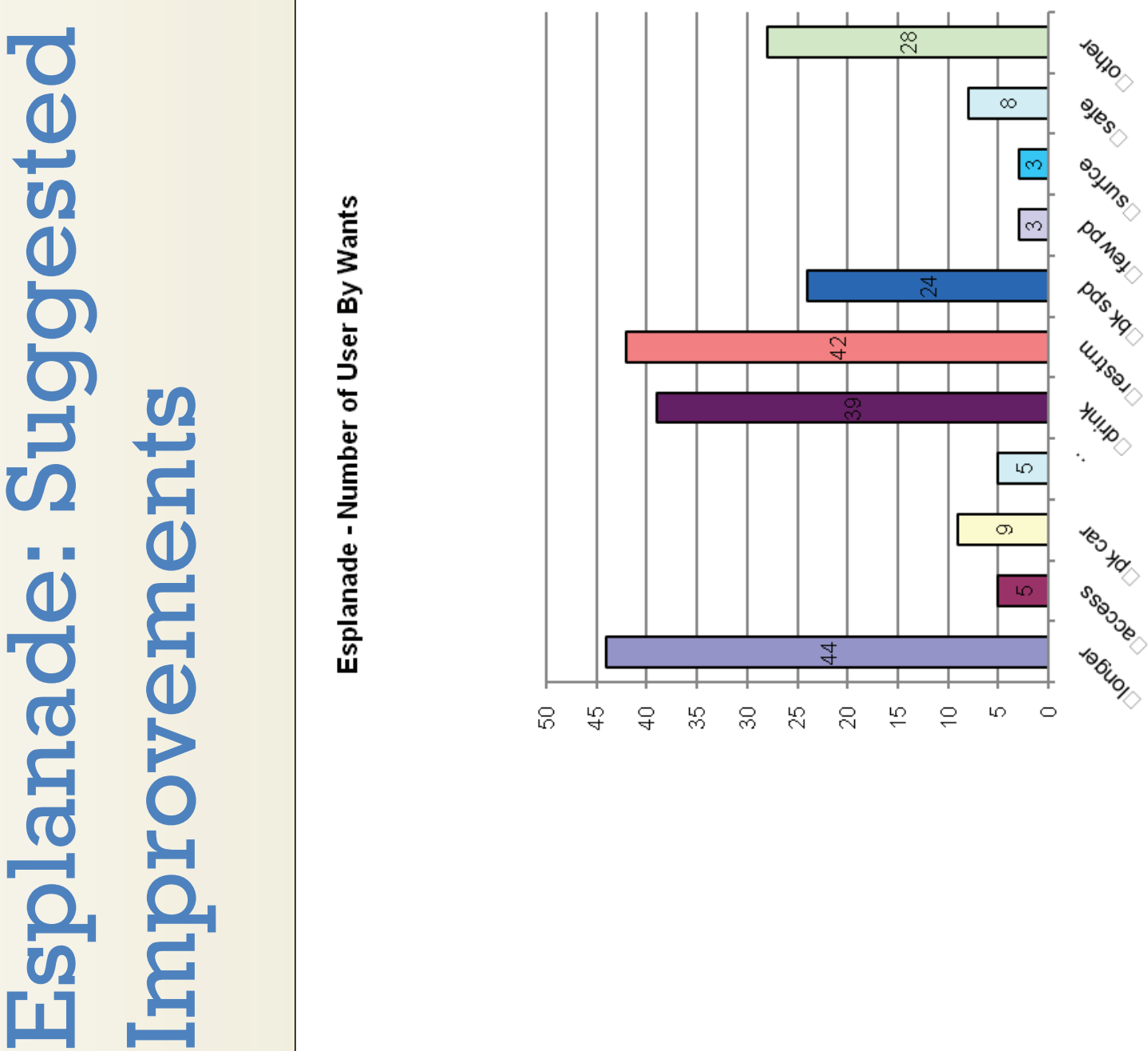


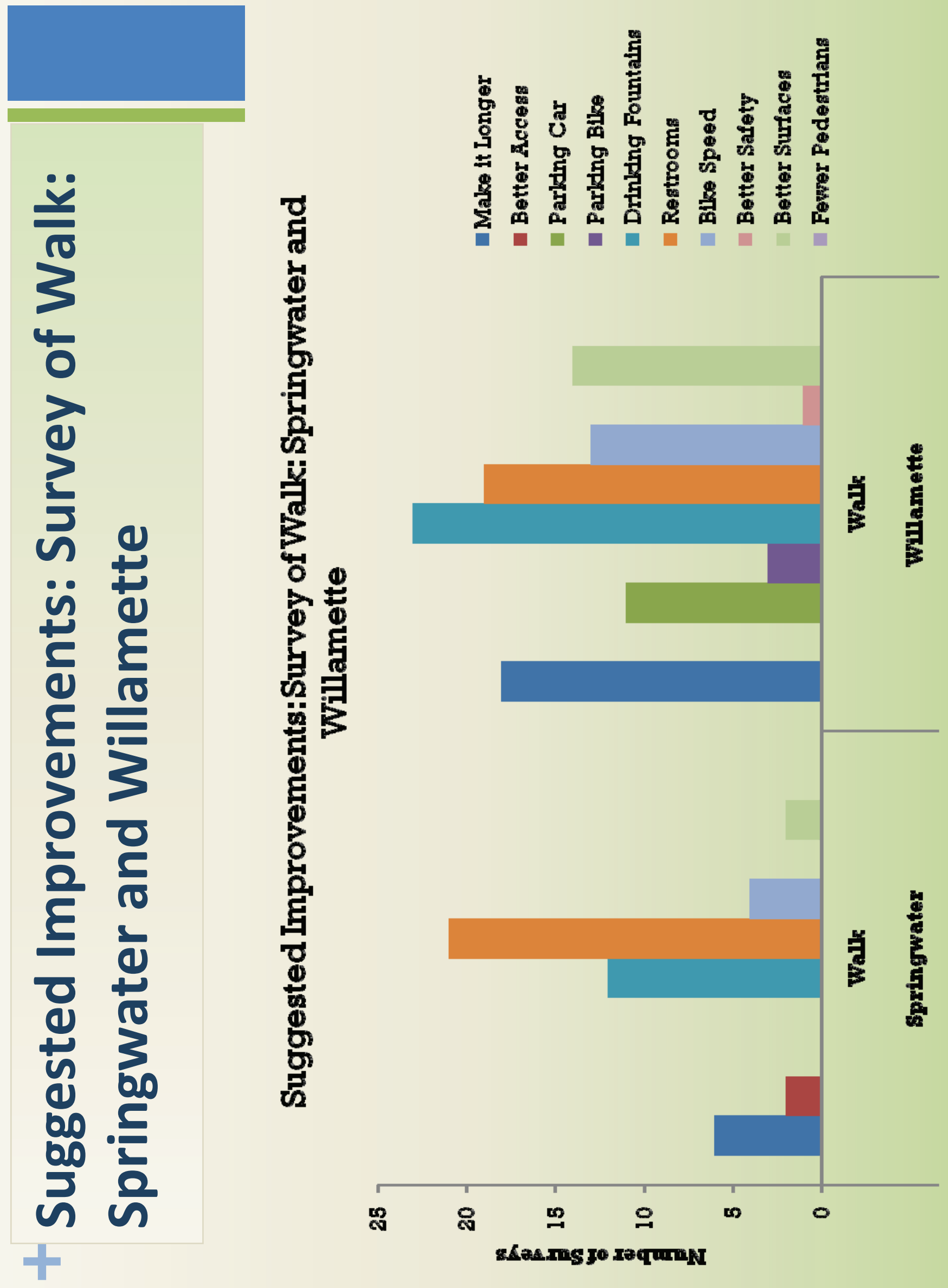




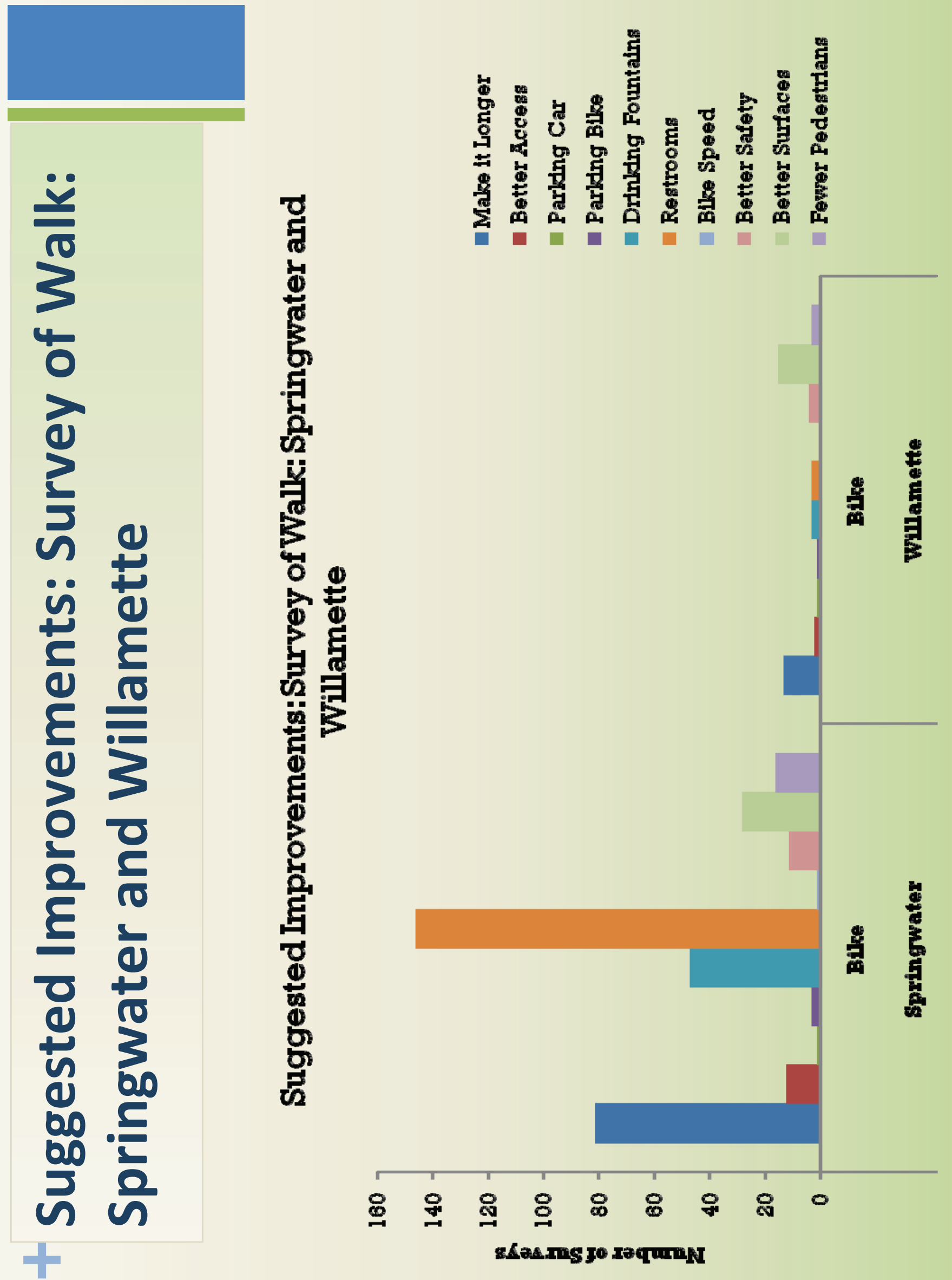




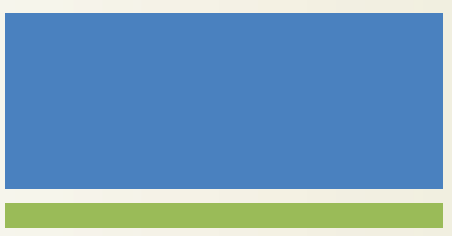

엄

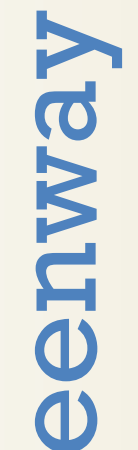

눙 호

(1)

(1)

$>0$

$0 \quad 1$

40

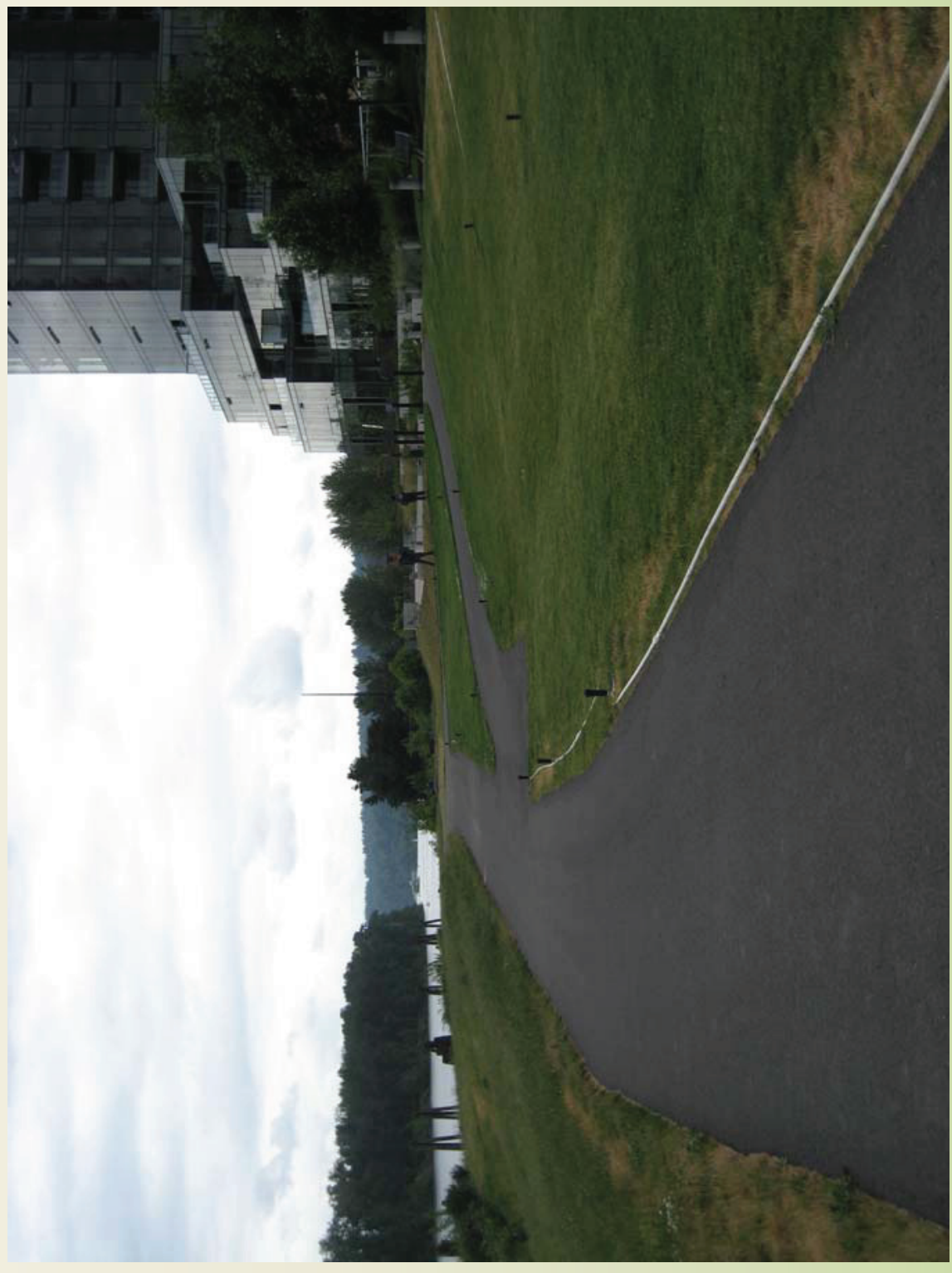

아 $>$

हु

$+$ 

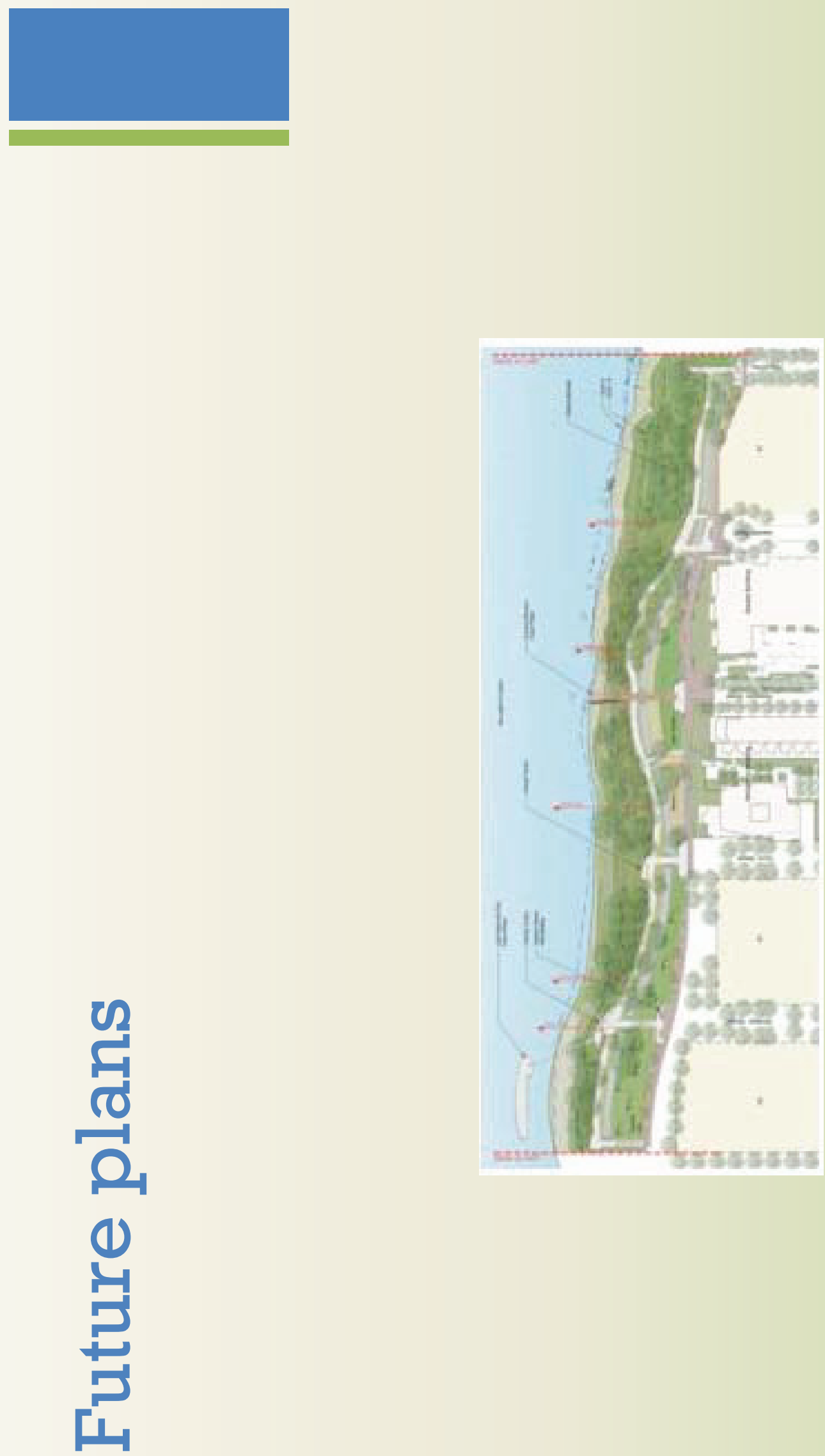

- 

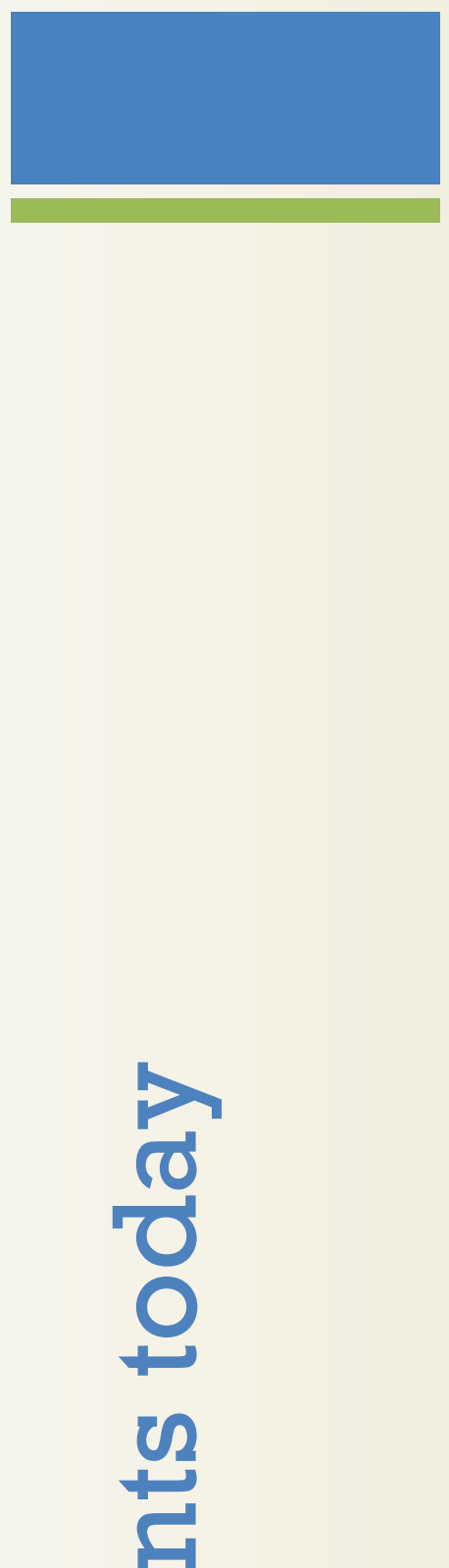

(1)

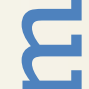

(1)

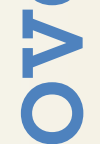

1
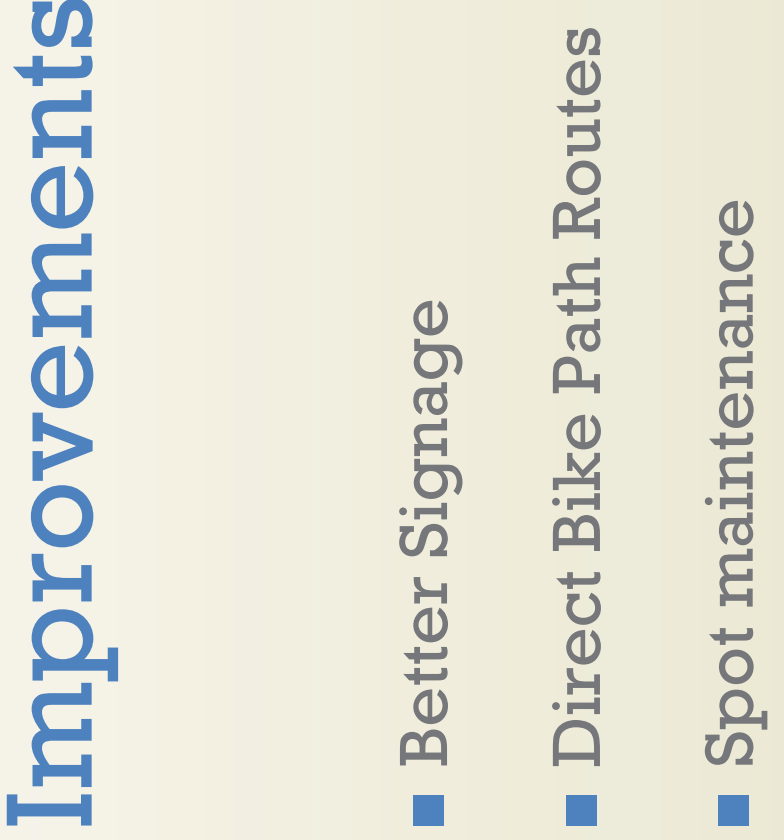

- 




\section{SOTREC \\ AND EDUCATION CONSORTIUM}

P.O. Box 751

Portland, OR 97207

OTREC is dedicated to stimulating and conducting collaborative multi-disciplinary research on multi-modal surface transportation issues, educating a diverse array of current practitioners and future leaders in the transportation field, and encouraging implementation of relevant research results. 